UNIVERSIDADE DE SÃO PAULO

FACULDADE DE ECONOMIA, ADMINISTRAÇÃO E CONTABILIDADE DEPARTAMENTO DE ADMINISTRAÇÃO

CONFLITOS NO PERÍODO PÓS-PRIVATIZAÇÃO DAS TELECOMUNICAÇÕES: UM ESTUDO DE CASO

VERÔNICA ANGÉLICA FREITAS DE PAULA

Orientador: Prof. Dr. Dante Pinheiro Martinelli

SÃO PAULO

2003 
UNIVERSIDADE DE SÃO PAULO

FACULDADE DE ECONOMIA, ADMINISTRAÇÃO E CONTABILIDADE DEPARTAMENTO DE ADMINISTRAÇÃO

CONFLITOS NO PERÍODO PÓS-PRIVATIZAÇÃO DAS TELECOMUNICAÇÕES: UM ESTUDO DE CASO

VERÔNICA ANGÉLICA FREITAS DE PAULA

Orientador: Prof. Dr. Dante Pinheiro Martinelli

SÃO PAULO

2003 
Reitor Universidade de São Paulo:

Prof. Dr. Adolpho José Melphi

Diretor Faculdade de Economia Administração e Contabilidade:

Profa. Dra. Maria Tereza Leme Fleury

Chefe do Departamento de Administração:

Prof. Dr. Eduardo Pinheiro Gondin de Vasconcellos 


\title{
CONFLITOS NO PERÍODO PÓS-PRIVATIZAÇÃO DAS TELECOMUNICAÇÕES: UM ESTUDO DE CASO
}

\author{
Dissertação apresentada à Faculdade de \\ Economia, Administração e Contabilidade da \\ Universidade de São Paulo, para a obtenção do \\ título de Mestre em Administração pelo Curso de \\ Pós-Graduação em Administração. \\ Orientador: Prof. Dr. Dante Pinheiro \\ Martinelli
}


PAULA, Verônica Angélica Freitas de.

Conflitos no Período Pós-Privatização das Telecomunicações: um estudo de caso. São Paulo, 2003.

102 p.: il.; $30 \mathrm{~cm}$

Dissertação de Mestrado apresentada à Faculdade de Economia, Administração e Contabilidade da Universidade de São Paulo/USP - Área de concentração: Administração.

Orientador: Martinelli, Dante Pinheiro.

1. Conflitos. 2. Telecomunicações. 3. Concorrência 
Dedico àqueles que buscam soluções... 
Agradeço minha família pelo apoio às minhas iniciativas.

Ao Professor Dante, pela colaboração, suporte e amizade constantes.

À Carla e à Melissa, pelo companheirismo nessa jornada conjunta.

Ao Marcos, pela presença e apoio incondicionais.

Às Professoras Daniela Carnio e Jete Jane Fiorati e a todos aqueles que contribuíram direta ou indiretamente para este trabalho.

E, acima de tudo, agradeço a Deus, que me possibilita seguir no caminho do conhecimento. 
SUMÁRIO

Lista de Siglas.

Introdução

I - O Estado Brasileiro e as Privatizações

1.1 Contexto Histórico das Privatizações............................... 18

1.2 A Privatização do Setor de Telecomunicações no Brasil.. 23

1.3 Agência Nacional de Telecomunicações - ANATEL....... 27

1.4 Modelo de Privatização das Telecomunicações no Brasil............................................................ 28

1.5 Os Contratos Administrativos........................................ 30

1.5.1 Contratos de Concessão........................................... 33

1.5.2 Os Contratos de Concessão no Setor de Telecomunicações......................................................... 34

II - Concorrência e Competitividade: aspectos gerais............. 37

2.1 Ameaça de Entrada.......................................................... 38

2.2 Intensidade da Rivalidade entre os Concorrentes Existentes........................................................... 40

2.3 Pressão dos Produtos Substitutos...................................... 41

2.4 Poder de Negociação dos Compradores............................ 42

2.5 Poder de Negociação dos Fornecedores............................. 42

2.6 Conselho Administrativo de Defesa Econômica-CADE. 47

III - Solução de Conflitos no Setor de Telecomunicações........ 50

3.1 O Conflito e suas Classificações........................................ 51

3.2 Formas de Solução de Conflitos...................................... 52

3.3 A Negociação como Forma de Solução de Conflitos........ 55

3.3.1 As Variáveis Básicas da Negociação....................... 58

3.4 Conflitos no Setor de Telecomunicações no Brasil........... 58 
IV - Procedimentos Metodológicos........................................... 61

4.1 Perguntas e Modelo de Pesquisa........................................ 63

4.2 Coleta de Dados: Método e Instrumento........................... 65

V - Análise do Conflito Embratel x Telefônica na Antecipação de Metas..................................................... 66

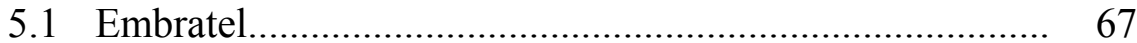

5.2 Telefônica................................................................... 68

5.3 O Conflito Embratel x Telefônica..................................... $\quad 70$

5.4 Análise das Entrevistas................................................ 72

Considerações Finais e Limitações do Estudo................... 78

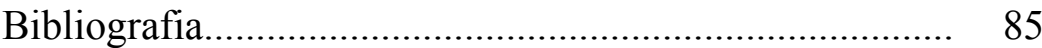

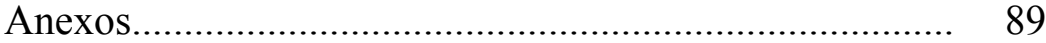




\section{RESUMO}

O objetivo do presente estudo é verificar questões relacionadas à solução de conflitos no setor de telecomunicações no período pós-privatização, analisando de forma detalhada um conflito ocorrido entre a Embratel e a Telefônica, com base nos conceitos de negociação, concorrência e solução de conflitos.

Inicialmente são apresentados conceitos sobre a forma de organização do Estado e a tendência mundial de flexibilização de monopólios, culminando com a privatização de setores essenciais da economia, como o de telecomunicações; a criação de uma agência nacional para regular o setor e garantir o modelo de competição e universalização; concorrência e competitividade; e as formas de solução de conflitos, com destaque para o setor de telecomunicações no Brasil.

Para o estudo de caso, são coletadas informações em fontes secundárias e são realizadas entrevistas na Telefônica e na ANATEL e contato com pessoa indicada pelo CADE.

Com os dados coletados é possível analisar o conflito ocorrido após o cumprimento antecipado de metas da Telefônica, o que possibilitou a essa empresa atuar na Região de concessão da Embratel, e a posição dos agentes envolvidos sobre o contexto atual do setor privatizado. 


\begin{abstract}
The aim of this paper is to verify some issues related to conflict resolution in the telecommunications sector on the period after the privatization, analyzing in a minucious way a conflict occurred between Embratel and Telefonica, based on the concepts of negotiation, competitivity and conflict resolution.

First of all some concepts about the organization of the State and the world tendency of monopoly flexibilization, including the economy essential sectors privatization; the creation of a national agency to rule the sector and assure the eficiency of a competion and universalization model; competitivity; and the conflict resolution forms, specially for the telecommunications sector, are presented.

For the study case, informations are taken from secondary sources and interviews at Telefonica and ANATEL, as well as a contact with a lawyer indicated by CADE, are made.

With the joint of all the information, it is possible to analyze the conflict ocurred after the early achievement of the goals set when the privatization took place, by Telefonica, what made this company able to offer different services in the area first set for Embratel, and also analyze the position of the agents related to the conflict and their opinion about the actual context of the telecommunications sector.
\end{abstract}




\section{LISTA DE SIGLAS}

ADR - Alternative Dispute Resolution

AICE - Acesso Individual Classe Especial

ANATEL - Agência Nacional de Telecomunicações

CADE - Conselho Administrativo de Defesa Econômica

CETERP - Centrais Telefônicas de Ribeirão Preto

DDD - Discagem Direta à Distância

LGT - Lei Geral de Telecomunicações

OMC - Organização Mundial do Comércio

PGMQ - Plano de Metas de Qualidade

PGMU - Plano de Metas de Universalização

PGO - Plano Geral de Outorgas

PST - Posto de Serviço de Telecomunicações

RGI - Regulamento Geral de Interconexão

SDE - Secretaria de Direito Econômico

SEAE - Secretaria de Acompanhamento Econômico do Ministério da Fazenda

STFC - Serviço Telefônico Fixo Comutado

TELESP - Telecomunicações de São Paulo S/A

TGS - Teoria Geral de Sistemas

TRF - Tribunal Regional Federal 


\section{INTRODUÇÃO}

Após a Segunda Guerra Mundial, com o aumento das demandas econômicas e sociais da população em geral ao Estado, se consolida a idéia do Estado Social de Direito, cuja missão é buscar a igualdade entre os homens. Considera-se que, como os homens não nascem iguais em direitos (exatamente em oposição às idéias do liberalismo, vigentes até então), cabe ao Estado buscar e assegurar essa igualdade intervindo na ordem social e econômica. $\mathrm{O}$ Estado passa a atuar em todos os setores da vida social, o que causou considerável aumento das funções do Estado. Com o conseqüente aumento do aparelhamento do Estado, há tendência à burocratização, provocando escassez de recursos e ineficiência na prestação dos serviços públicos.

Surge, então, inserida na tendência mundial de desestatização dos serviços públicos, reforçada pela globalização e no contexto de quebra de monopólios mediado pela Organização Mundial do Comércio (OMC), a privatização como um conceito amplo, que engloba todos os meios de diminuição do tamanho do aparelho administrativo do Estado, quebra de monopólios, delegação de serviços públicos ao particular, parcerias do Estado com entidades públicas ou privadas e terceirização.

O processo de privatização das telecomunicações no Brasil teve início com a Emenda Constitucional $\mathrm{n}^{\mathrm{o}} 8$, de 1995.

O Estado, então, baseado no modelo de competição e universalização, transferiu para a iniciativa privada o controle acionário das empresas de telecomunicações, mantendo o controle da prestação do serviço pela regulamentação.

Em 1997, foi criada a ANATEL - Agência Nacional de Telecomunicações, um órgão regulador, independente e autônomo, ao qual compete a regulamentação e fiscalização do setor de telecomunicações, além da mediação entre governo, empresas e sociedade/usuários.

Foram definidos dois regimes jurídicos para a exploração dos serviços de telecomunicações: o público e o privado.

As empresas privadas que monopolizaram os serviços de telefonia fixa em cada região, em regime público, ficaram, então, responsáveis pelo cumprimento dos deveres de universalização e continuidade do serviço de telecomunicações (chamadas concessionárias). Os novos concorrentes, chamados empresas-espelho, se sujeitaram ao regime privado.

O modelo de privatização das telecomunicações no Brasil prevê cenário de competição total, ou seja, livre concorrência entre empresas concessionárias e autorizadas a partir de 31 
de dezembro de 2003, quando fica autorizada a liberação das concessionárias para a prestação de todo e qualquer serviço de telecomunicação. Contudo, o modelo também previu a possibilidade de essa liberação ocorrer já a partir de 01 de janeiro de 2002 caso as concessionárias conseguissem cumprir todas as metas de universalização previstas nos contratos de concessão.

Em 30 de julho de 1998 foi realizado o leilão das empresas do sistema TELEBRÁS. Findo o leilão, há o chamado período pós-privatização das telecomunicações.

O primeiro estágio deste período é a transição, que durou até 2002, caracterizando-se pela competição limitada e concentrada na telefonia interurbana.

O segundo estágio, de competição total, ainda é uma incógnita, pois a ANATEL não definiu os critérios e regras para licenciamento de novas operadoras e ampliação do campo de atuação das atuais concessionárias.

A liberação das concessionárias para a prestação de todos os serviços de telecomunicações a partir de 2002, prevista na Lei Geral de Telecomunicações, antecipou o considerável aumento da concorrência, provocando conflitos entre as concessionárias e as futuras empresas autorizadas que atuarão em outras regiões (além daquelas em que são concessionárias).

Assim, a principal contribuição do trabalho é apresentar os conflitos decorrentes da liberalização das concessionárias para a prestação de todos os serviços de telecomunicações a partir de 2002, enfatizando as melhores alternativas para a solução dos impasses no ambiente de competição total, descrevendo os modelos que estão sendo adotados.

O estudo analisa o caso envolvendo a Embratel e a Telefônica, enfatizando os conflitos ocorridos entre as empresas e a(s) forma(s) de solução encontrada(s), verificando os recursos gastos e a satisfação das partes com o resultado final.

O acesso aos dados desde a promulgação da Lei Mínima e da Lei Geral das Telecomunicações (respectivamente em 1996 e 1997), passando pela Emenda Constitucional $\mathrm{n}^{\mathrm{o}} 8$, que liberou a privatização das telecomunicações no Brasil, até o presente momento, de transição da competição regulada para o ambiente de competição total, é amplo, principalmente em função dos recursos tecnológicos disponíveis (Internet, por exemplo) e da realização de pesquisas conjuntas com outros estudiosos da questão das telecomunicações.

As principais notícias e acontecimentos atuais referentes às telecomunicações são conhecidos e obtidos a partir de fontes como jornais, revistas, noticiários e artigos. $\mathrm{O}$ detalhamento dessas informações, assim como a visão e o posicionamento da agência 
reguladora, do CADE e mesmo das empresas neles envolvidas, é obtido e analisado a partir de entrevistas em algumas dessas organizações.

O estudo tem abrangência nacional, uma vez que todas as empresas do antigo Sistema TELEBRÁS foram privatizadas no leilão de 30 de julho de 1998.

As análises são feitas dentro de um contexto mais amplo, englobando todos os aspectos das telecomunicações constantes deste e dos demais trabalhos desenvolvidos sob a mesma orientação.

O estudo tem como problema de pesquisa: no período pós-privatização das telecomunicações, quais aspectos influenciam a solução dos conflitos entre as empresas em um ambiente de competição total?

O presente estudo tem como objetivo geral analisar o conflito entre a Embratel e a Telefônica, no período pós-privatização das telecomunicações (fase da liberalização), com base nos conceitos de negociação, conflitos e concorrência.

A pesquisa tem os seguintes objetivos específicos:

a) compreender o período pós-privatização das telecomunicações, enfatizando o estágio da competição total (após 2002);

b) analisar a concorrência no âmbito do modelo de privatização das telecomunicações;

c) definir aspectos da negociação ganha-ganha para que as empresas envolvidas busquem benefícios mútuos;

d) analisar os conflitos decorrentes do processo de liberalização das telecomunicações, focando o caso do conflito entre Embratel e Telefônica;

e) verificar as formas de solução de conflitos adotadas pelas empresas do setor de telecomunicações, em especial Embratel e Telefônica.

Não é objetivo deste trabalho analisar a cadeia do setor de telecomunicações, portanto são desconsiderados para efeitos de análise os aspectos concernentes a fornecedores e usuários do serviço de telefonia. O foco da análise é mantido nas relações entre os concorrentes do setor após a privatização, mais especificamente nos conflitos surgidos no período pós-privatização, em que há aumento da concorrência, principalmente na prestação de serviços telefônicos para chamadas de longa distância nacional e internacional, com as antecipações de meta e liberações de concessionárias para a prestação de serviços diferenciados e em regiões geográficas diferentes, conforme previsto no Plano de Metas e no Plano de Outorgas. 
O capítulo I apresenta o processo de privatização do setor de telecomunicações no Brasil dentro do contexto de desestatização, a partir das alterações na forma de atuação do Estado na vida econômica do país, trazendo conceitos sobre a organização estatal e a tendência mundial de flexibilização de monopólios, culminando com a privatização de setores essenciais da economia, como o de telecomunicações. A criação da agência reguladora, com o papel de fiscalizar e regulamentar o setor privatizado, garantindo o modelo de competição e universalização, também é abordada nesse capítulo.

O modelo de privatização adotado para o setor de telecomunicações contempla a universalização e a competição, sendo esta última o tema do capítulo II. Ao tratar de concorrência e competitividade, o capítulo também traz definições sobre o papel e a atuação do Conselho Administrativo de Defesa Econômica (CADE).

O ambiente de competição reforça a ocorrência de conflitos entre operadoras. As formas de solução desses conflitos são abordadas no capítulo III, que traz, ainda, alguns exemplos de conflitos ocorridos no período pós-privatização das telecomunicações no Brasil.

Os procedimentos metodológicos adotados para a elaboração do presente trabalho são apresentados no capítulo IV.

E o capítulo V traz a análise do conflito entre Embratel e Telefônica no caso de antecipação de metas da concessionária de telefonia fixa local da região III. 


\section{CAPÍTULO I}

\section{O Estado Brasileiro e as Privatizações}

Para se entender a questão da privatização das telecomunicações no Brasil, bem como a formação de uma agência reguladora (a ANATEL) com funções precípuas de fiscalizar e regulamentar a prestação de um serviço público, é imprescindível conhecer aspectos referentes à administração pública e o processo de reforma do Estado brasileiro, principalmente a partir do Plano Diretor de Reforma.

O poder estatal é uno, indelegável e indivisível, mas se reparte em três funções: legislativa, executiva e jurisdicional. Dessa repartição decorrem os três poderes estatais, poder legislativo, poder executivo e poder judiciário, sendo que a cada um deles é atribuída uma atividade típica (legislar, ou seja, estabelecer regras gerais e abstratas; satisfazer as necessidades coletivas com a realização de atos concretos e julgar, solucionar conflitos de interesses com a imposição da lei, respectivamente), o que não impede que eles possam exercer, atipicamente, as atividades próprias dos outros poderes.

Surgem, ainda, as funções políticas ou de governo e as funções administrativas do Estado. As funções políticas referem-se à elaboração das diretrizes e planos de governo, e são atribuídas, preferencialmente, aos poderes executivo e legislativo. A função administrativa, por sua vez, caracteriza-se pela realização do bem comum, e é atribuída aos órgãos do poder executivo. O legislativo e o judiciário podem realizar, atipicamente, função administrativa.

Administração pública, em sentido estrito, é a atividade que o Estado desenvolve, por meio de seus órgãos, pessoas jurídicas e agentes, para a consecução do interesse público. Corresponde à função administrativa, que é preferencialmente exercida pelo poder executivo.

Em sentido objetivo, a administração pública corresponde à função administrativa do Estado, ou seja, abrange o fomento (incentivo à iniciativa privada), a polícia administrativa, a intervenção e o serviço público. Assim, a administração passa a ser, em sentido objetivo, "a atividade concreta e imediata do Estado, sob regime de direito público, para a consecução dos interesses coletivos" (DI PIETRO, 1998, p.55).

Em sentido subjetivo, a administração pública compreende a administração direta, realizada pelos órgãos integrantes das pessoas jurídicas políticas, que são a União, estados, municípios e Distrito Federal, e a administração indireta, realizada por pessoas jurídicas 
públicas ou privadas que agem em nome do Estado para desempenhar serviços públicos, e que têm personalidade jurídica própria (autarquias, empresas públicas, sociedades de economia mista e fundações públicas). Então, define-se a administração pública, em sentido subjetivo, como sendo o "conjunto de órgãos e de pessoas jurídicas aos quais a lei atribui o exercício da função administrativa do Estado" (DI PIETRO, 1998, p.56).

Há, portanto, centralização (ou descentralização) em sentido político (o que corresponde às formas de organização do Estado) e em sentido administrativo (formas diversas de organização da administração pública). A centralização administrativa, ou administração pública direta, é exercida diretamente por meio de seus próprios órgãos. A descentralização administrativa, ou administração pública indireta, é exercida indiretamente, por meio da transferência de atribuições a outras pessoas, físicas ou jurídicas, públicas ou privadas.

As modalidades de descentralização são:

1. territorial ou geográfica, que ocorre quando uma entidade local, delimitada geograficamente e com personalidade jurídica própria, de direito público, tem capacidade administrativa genérica, exercendo grande parte dos encargos públicos de interesse da coletividade e sujeita a controle do poder central. No Brasil, Di Pietro (1998) cita como exemplo os territórios;

2. por serviços, funcional ou técnica, que ocorre quando o poder público cria uma pessoa jurídica de direito público ou privada, à qual compete a titularidade e a execução de determinado serviço público. No Brasil, a criação deste ente dá-se por lei, correspondendo às autarquias, fundações governamentais, sociedades de economia mista e empresas públicas. O ente descentralizado possui personalidade jurídica própria, patrimônio próprio e sujeita-se ao princípio da especialização (não pode afastar-se dos fins que justificaram a sua criação) e ao controle ou tutela do ente descentralizador;

3. por colaboração, na qual o poder público conserva a titularidade do serviço, mas transfere a sua execução a pessoa jurídica de direito privado, por meio de contrato (concessão) ou ato administrativo unilateral (permissão).

Em qualquer das três modalidades, nota-se que há transferência de atribuições de uma pessoa jurídica pública para outra pessoa jurídica, gozando o ente descentralizado de capacidade de auto-administração. Há, necessariamente, transferência de uma atividade própria da administração pública, ou seja, de um serviço público. 
Diz Marçal Justen Filho (2003, p.119):

A descentralização caracteriza-se pela criação de novo sujeito, dotado de personalidade jurídica autônoma e patrimônio próprio. Esse sujeito integrará, porém, a Administração Pública, assujeitado ao titular do serviço. $\mathrm{Na}$ hipótese da descentralização, não se efetiva a atribuição do serviço a setores privados ou a terceiros, para desempenho por conta e risco alheios o titular da competência mantém os serviços em sua órbita jurídica, mas sob modelo descentralizado.

Meirelles (1998, p.297) apresenta o seguinte conceito de serviço público: “é todo aquele prestado pela Administração ou por seus delegados, sob normas e controles estatais, para satisfazer necessidades essenciais ou secundárias da coletividade ou simples conveniência do Estado". Nos dizeres de Di Pietro (1998, p.84), serviço público refere-se a "toda atividade material que a lei atribui ao Estado para que a exerça diretamente ou por meio de seus delegados, com o objetivo de satisfazer concretamente às necessidades coletivas, sob regime jurídico total ou parcialmente público".

Grotti (2002) reforça o conceito de serviço público como sendo aquele que a lei atribui ao Poder Público e que pode por este ser executado diretamente ou mediante concessão ou permissão.

Para Celso Antônio Bandeira de Mello (1987, p.18) “o serviço público apresenta dois elementos essenciais, quais sejam, a prestação de uma utilidade material fruível diretamente pelos indivíduos e o específico regime de direito público a que se acha subordinada a prestação dessa utilidade, pelo Estado ou por quem lhe faça as vezes".

Para Leon Duguit (1923 apud SALOMÃO FILHO, 2001, p. 18) o Estado nada mais é do que "uma cooperação de serviços públicos organizados e controlados por governantes".

Se o Estado exerce uma atividade não definida, por lei, como serviço público, há atividade econômica, com fundamento no artigo 173 da Constituição Federal ${ }^{1}$, não podendo

\footnotetext{
1 “Artigo 173 - Ressalvados os casos previstos nesta Constituição, a exploração direta de atividade econômica pelo Estado só será permitida quando necessária aos imperativos da segurança nacional ou a relevante interesse coletivo, conforme definidos em lei.

$\S 1^{\circ}$ - A lei estabelecerá o estatuto jurídico da empresa pública, da sociedade de economia mista e de suas subsidiárias que explorem atividade econômica de produção ou comercialização de bens ou de prestação de serviços, dispondo sobre:

I - sua função social e formas de fiscalização pelo Estado e pela Sociedade;

II - a sujeição ao regime jurídico próprio das empresas privadas, inclusive quanto aos direitos e obrigações civis, comerciais, trabalhistas e tributários;

III - licitação e contratação de obras, serviços, compras e alienações, observados os princípios da administração pública;

IV - a constituição e o funcionamento dos conselhos de administração e fiscal, com a participação de acionistas minoritários;

$\mathrm{V}$ - os mandatos, a avaliação de desempenho e a responsabilidade dos administradores.

$\S 2^{\circ}$ - As empresas públicas e as sociedades de economia mista não poderão gozar de privilégios fiscais não extensivos às do setor privado.

$\S 3^{\circ}$ - A lei regulamentará as relações da empresa pública com o Estado e a sociedade.
} 
se falar em descentralização administrativa, pois o que ocorre é que o Estado sai de seu campo de atuação para desempenhar atividade com intervenção no domínio econômico.

Do mesmo modo, não se pode dizer que todos os serviços públicos estão excluídos da possibilidade de atuação de particulares (GROTTI, 2002, p.47).

\begin{abstract}
Com efeito, cumpre distinguir entre serviços públicos privativos do Estado e os serviços públicos não-privativos do Estado. Nesta última categoria estão os serviços de educação e saúde, que não serão serviços públicos quando desempenhados pelos particulares, uma vez que a Constituição não limitou a prestação deles ao Estado ou a quem lhe faça as vezes. Embora a assistência a saúde seja livre à iniciativa privada, os serviços são de todo modo qualificados como de relevância pública.

Submetem-se, apenas, a uma autorização e fiscalização do Poder Público, que as efetua no exercício normal da sua polícia administrativa. O Estado, portanto, jamais poderia pretender outorga-los em concessão a alguém, sob pena de ferir os direitos de presta-los que assistem às demais pessoas que preencham os requisitos legais necessários à comprovação de suas habilitações.
\end{abstract}

Destes conceitos depreende-se que há serviços públicos exclusivos do Estado ou seus delegados, que prestam os serviços mediante permissão, concessão ou autorização, e há serviços que podem ser prestados livremente por particulares, mas que, por serem de relevância pública, ficam submetidos a fiscalização do Estado.

A possibilidade de prestação de serviço público por particular mediante autorização estatal está prevista na Constituição Federal (artigo 21) embora a própria Carta Magna traga, em seu artigo 175, somente as figuras da concessão e da permissão.

Vários autores discutem a doutrina pertinente ao instituto da autorização na tentativa de identificar a real intenção do legislador pátrio ao não manter uniformidade na utilização deste termo na Constituição Federal.

Grotti (2002) corrobora a definição de Maria Sylvia Zanella Di Pietro para a autorização de serviço público: "é o ato administrativo, unilateral e discricionário pelo qual o Poder Público delega ao particular a exploração de serviço público, a título precário” (DI PIETRO, 2002 apud GROTTI, 2002, p.66-67).

A partir dessa definição nota-se uma diferenciação entre os institutos da concessão, permissão e autorização no que tange ao grau de controle e participação do poder público na execução de serviços delegados a particulares.

A autorização de serviços públicos é feita no interesse do particular, não para a satisfação de necessidades da coletividade e, portanto, como os terceiros não poderão usufruir

$\S 4^{\circ}$ - A lei reprimirá o abuso do poder econômico que vise à dominação dos mercados, à eliminação da concorrência e ao aumento arbitrário dos lucros. 
dessa atividade, não há que se falar em prerrogativas públicas ao ente que recebeu a autorização.

No caso da concessão e da permissão, a atividade delegada deverá satisfazer necessidades da coletividade, de forma que o regime jurídico de prestação do serviço será o público, tendo o concessionário ou permissionário as mesmas prerrogativas e obrigações que o poder público.

Para Justen Filho (2003, p.130):
A lei poderá subordinar o exercício de certas atividades a uma autorização estatal prévia. $\mathrm{O}$ ato estatal destina-se verificar o preenchimento pelo particular dos requisitos necessários. A intervenção do Estado, nesses casos, não atinge a natureza do serviço nem altera o regime jurídico sob o qual se desenvolve, ainda que se imponham requisitos para o desempenho das atividades e se as subordine a controle de intensidade variável.
Em princípio, todo aquele que preencher os requisitos previstos em lei terá direito a desenvolver as atividades pertinentes.
$[\ldots]$
Enfim, concedem-se serviços públicos; autorizam-se serviços privados.

A principal diferença entre concessão e permissão é que a permissão nada mais é do que um ato administrativo, discricionário e precário, e, como, tal, unilateral, não constituindo contrato, que requer bilateralidade. Há necessidade de se diferenciar os dois institutos em função do artigo $175^{2}$, caput, da Constituição Federal.

O contrato de concessão não pode ser rescindido a qualquer tempo, pois a concessão é um contrato que já vem com prazo estipulado de duração. Se a Administração o rescinde, o concessionário tem direito a indenização. Já a permissão, conforme mencionado acima, é ato discricionário e precário, e como tal pode ser revogado livremente, a qualquer tempo, pela administração pública.

Independente dos serviços públicos serem prestados na forma direta ou indireta, os prestadores desses serviços no Brasil estão obrigados, por norma constitucional, a manter serviço adequado. Dinorá Grotti (2002, p.49) apresenta como conceito de serviço adequado aquele trazido pelo artigo $6^{\circ}$ da Lei 8.987 , de 13 de fevereiro de 1995: "o que satisfaz as condições de: regularidade, continuidade, eficiência, segurança, atualidade, generalidade, cortesia na sua prestação e modicidade das tarifas".

Isso significa que concessionários e permissionários de serviços públicos também têm o dever de prestação de serviço adequado, eficiente, seguro e contínuo (quando se tratar de

$\S 5^{\circ}$ - A lei, sem prejuízo da responsabilidade individual dos dirigentes da pessoa jurídica, estabelecerá a responsabilidade desta, sujeitando-a às punições compatíveis com sua natureza, nos atos praticados contra a ordem econômica e financeira e contra a economia popular".

2 “Artigo 175 - Incumbe ao Poder Público, na forma da lei, diretamente ou sob regime de concessão ou permissão, sempre através de licitação, a prestação de serviços públicos”. 
serviços essenciais), devendo, inclusive, reparar danos que eventualmente cause pela não prestação do serviço, tanto quanto o Estado atuando diretamente. Assim, estão sujeitos aos princípios de prestação de serviço público, como continuidade, obrigatoriedade, mutabilidade, regularidade cortesia e eficiência, entre outros.

Cabe distinguir, ainda, a concessão de serviço público da "concessão de atividade econômica", instituto inexistente.

Não é cabível cogitar de "concessão de atividade econômica". Bem por isso, a delegação a particular não altera o regime jurídico aplicável: o serviço continua a caracterizar-se como público, sujeito ao mesmo regime jurídico aplicável caso desempenhado diretamente pelo próprio Estado (JUSTEN FILHO, 2003, p.118).

A privatização de setores essenciais, como telecomunicações, energia elétrica e exploração de petróleo, representa uma transferência de prestação ou exploração de serviço ou produto para o particular, mas a manutenção do regime público significa que esses particulares carregam a obediência aos deveres e princípios de prestação de serviços públicos.

\subsection{Contexto Histórico das Privatizacões}

Após a Segunda Guerra Mundial, com o aumento das demandas econômicas e sociais da população em geral ao Estado, consolida-se a idéia do Estado Social de Direito, cuja missão é buscar a igualdade entre os homens. Considera-se que, como os homens não nascem iguais em direitos, cabe ao Estado buscar e assegurar essa igualdade, intervindo na ordem econômica e social. A preocupação com o bem comum e com o interesse público, não mais com o individualismo, conduziu a uma socialização.

Na União Soviética e nas democracias populares, implantou-se um Estado Socialista. Nas democracias ocidentais, implantou-se o Estado Social de Direito, com o Estado prestando serviços à população.

Esse intervencionismo estatal direto substituiu o modelo de Estado Liberal até então vigente, e que se baseava exatamente no princípio de não-intervenção do Estado na economia, o que significa dizer que o mercado se organizaria pela combinação de suas próprias forças (COELHO, 2002).

Di Pietro (1999, p.19-20) salienta:

Com o crescimento dos chamados direitos sociais e econômicos, postos perante o Estado, este ampliou desmesuradamente o rol de suas atribuições, adotando diferentes atitudes:

a) algumas atribuições foram assumidas pelo Estado como serviços públicos, entrando na categoria de serviços públicos comerciais, industriais e sociais; para desempenhar esses serviços, o Estado passou a criar maior número de empresas 
estatais e fundações;

b) outras atividades, também de natureza econômica, o Estado deixou na iniciativa privada, mas passou a exercê-las a título de intervenção no domínio econômico, por meio de sociedades de economia mista, empresas públicas e outras empresas sob controle acionário do Estado;

c) finalmente, outras atividades, o Estado nem definiu como serviço público nem passou a exercer a título de intervenção no domínio econômico; ele as deixou na iniciativa privada e limitou-se a fomentá-las, por considerá-las de interesse para a coletividade. Desenvolve-se, então, o fomento como uma atividade administrativa de incentivo à iniciativa privada de interesse público. O Estado fomenta a iniciativa privada por diferentes meios, como os honoríficos (prêmios, recompensas, títulos e menções honrosas), os jurídicos (outorga de privilégios próprios do Poder Público, que outras entidades não têm) e os econômicos (auxílios, subvenções, financiamentos, isenções fiscais, desapropriações por interesse social etc.).

A intervenção do Estado fez-se necessária, inclusive, pela ausência de recursos do setor privado para investimento em infra-estrutura e pela disputa estabelecida entre os modos de produção capitalista e socialista no pós-guerra.

É nesse contexto que o Estado assume funções básicas e essenciais, passando a atuar em setores como energia, telecomunicações, saneamento básico e transportes.

Além da atuação nesses setores da economia, nota-se que o Estado ampliou, também, o campo de ação do poder de polícia, antes restrito a questões relacionadas a manutenção da ordem pública e segurança, e que passou a incluir o controle sobre aspectos econômicos e sociais.

Di Pietro (1999, p.19-20) completa:

O crescimento do Estado também se deu pela ampliação do poder de polícia; este, no período do Estado liberal, limitava-se a restringir os direitos individuais em benefício da ordem pública, entendida como sinônimo de segurança pública; já no período do Estado Social de Direito, com o crescimento do Estado e a extensão de suas atividades a todos os setores da vida social, o poder de polícia também experimentou notável ampliação, em dois sentidos: de um lado, passou a atuar em setores não relacionados com a segurança, atingindo as relações entre particulares, anteriormente fora do alcance do Estado; o próprio conceito de ordem pública passou a abranger a ordem econômica e social, com medidas relativas às relações de emprego, ao mercado dos produtos de primeira necessidade, ao exercício das profissões, às comunicações, aos espetáculos públicos, ao meio ambiente, ao patrimônio histórico e artístico nacional, à saúde. De outro lado, o Estado passou a impor obrigações de fazer, como o cultivo da terra, o aproveitamento do solo, a venda de produtos, distanciando-se, também sob esse aspecto, da polícia tradicional, que só impunha obrigações de não fazer.

O Estado passou, então, a atuar em todos os setores da vida social. Há considerável aumento das funções do Estado, fortalecendo o Poder Executivo e ameaçando o princípio da separação de poderes.

Este período apresenta como características principais a tendência à burocratização do mundo, na concepção de burocracia de Max Weber (1981 apud MAXIMIANO, 2000), o risco de ineficiência do Estado na prestação dos serviços, ou seja, de não consecução do objetivo inerente ao Estado Social Direito, que era exatamente assegurar o bem comum, e ameaça à liberdade individual, pela crescente intervenção estatal.

Salomão Filho (2002) ressalta que o Estado enquanto gestor máximo, superior, mas 
distante e abstrato, do sistema econômico, não consegue cumprir satisfatoriamente suas funções. Deve, então, passar a ser função do Estado a redistribuição, sem que isso signifique a diminuição de sua atuação no mercado.

Surge a idéia de um Estado Democrático de Direito, protetor das liberdades individuais e do bem comum, para suprir as deficiências apresentadas pelo Estado Social de Direito. O objetivo do Estado Democrático de Direito é aumentar a participação popular no processo político, nas decisões de governo e no próprio controle da administração pública.

Ao conceito do Estado Democrático de Direito, associa-se o princípio da subsidiariedade, formulado dentro da doutrina social da Igreja no final do século XIX. As principais idéias decorrentes do Estado Subsidiário são o respeito aos direitos individuais, com a primazia da iniciativa privada sobre a estatal, a limitação à intervenção estatal e a parceria entre público e privado, com a atuação do Estado no fomento, coordenação e fiscalização da iniciativa privada.

Notam-se algumas tendências decorrentes da aplicação do princípio da subsidiariedade:

- sociedade pluralista, com menos barreiras entre Estado e sociedade e mesma possibilidade de participação para os representantes de todos os setores da sociedade;

- diminuição do tamanho do Estado, principalmente por meio da privatização;

- incentivo à iniciativa privada de interesse público (fomento);

- parcerias entre o setor público e o setor privado;

- desregulamentação ou desregulação, com a ampliação da liberdade de atuação do cidadão, limitando os monopólios e permitindo que as empresas privadas atuem em regime de competição em diversos setores, como serviços públicos, telecomunicações e energia elétrica;

- interesse público como sinônimo de interesse do cidadão e não da Administração.

Salomão Filho (2001, p.15) afirma que a regulação "engloba toda forma de organização da atividade econômica através do Estado, seja a intervenção através da concessão de serviço público ou o exercício do poder de polícia”. Isso significa que a regulação está presente tanto quando o Estado concede a prestação do serviço ao particular e mantém o papel de regular essa atividade, controlando preços e garantindo a qualidade, exemplificativamente, quanto ao exercer seu papel de polícia administrativa, editando normas.

O mesmo autor (SALOMÃO FILHO, 2002) reprova a idéia de que a regulação deva ter como objetivo principal a criação de um sistema concorrencial. A grande função da 
regulação no Estado moderno deve ser a redistribuição, não somente macroeconômica, mas também setorial, de forma a possibilitar que o Estado tenha maior eficiência. A redistribuição pode se ser feita de formas diferentes.

\begin{abstract}
Ela pode ser direta, como ocorre, por exemplo, quando a regulação exige dos grandes produtores ou monopolistas que estendam seus serviços a consumidores (ou candidatos a consumidores) que a eles não têm acesso. É o que se tem, ultimamente, chamado de universalização de serviços. [...]

A redistribuição pode e deve também assumir outras formas. É preciso criar condições para que, entre consumidores e produtores, haja redistribuição. Como também hoje é pacífico, isso só ocorre através da existência de pluralidade de escolha, i.e de efetiva concorrência. É esse o sentido institucional da concorrência (SALOMÃO FILHO, 2002, p.13).
\end{abstract}

No Brasil, a Constituição Federal de 1988 já previa a possibilidade de prestação, pelo poder público, com a participação da comunidade, ou a prestação pelo particular, dos chamados serviços públicos sociais, especialmente saúde e ensino. Contudo, necessitando de maior eficiência na prestação dos serviços e vivendo uma situação de crise, principalmente financeira, o poder público não tem condições de cumprir, satisfatoriamente, todas as competências que lhe foram atribuídas pela Constituição Federal de 1988.

Surge, então, a privatização, um conceito amplo, que engloba todos os meios de redução do tamanho do aparelhamento administrativo do Estado, a quebra de monopólios, a delegação de serviços públicos ao particular (autorização, permissão e concessão), parcerias do Estado com entidades públicas ou privadas (convênios, consórcios e contratos de gestão) e a terceirização.

Há uma diminuição significativa do intervencionismo direto do Estado sobre a ordem econômica, inclusive pela transferência de atividades tradicionalmente monopolizadas pelo Estado para entes privados. É o chamado intervencionismo indireto (MARQUES NETO, 2002, p.74).

\footnotetext{
Trata-se, aqui, não mais da assunção pelo Estado da atividade econômica em si, mas de sua concreta atuação no fomento, na regulamentação, no monitoramento, na mediação, na fiscalização, no planejamento, na ordenação da economia. Enfim, cuida-se da atuação estatal fortemente influente (por indução ou coerção) da ação dos atores privados atuantes num dado segmento da economia.
}

Assim, o Estado deixa de exercer a atividade econômica, mas mantém uma intervenção indireta sobre a atividade em questão, inclusive com a criação de órgãos autônomos, como as agências reguladoras, para o exercício da função de regular o setor, sem vincular tal processo à idéia de monopólio estatal. Essencialmente nos setores de maior utilidade e relevância pública, como os setores de energia elétrica e telecomunicações, o Estado deve garantir o acesso da população aos serviços, embora a prestação dos mesmos 
tenha sido deslocada ao setor privado.

Com a modificação do modelo administrativo do Estado, principalmente com a privatização de setores relevantes da economia, há que se falar em um novo modelo de regulação para a competição nesses setores. O foco principal da mudança está na transferência da titularidade do serviço do Estado para o particular.

O monopólio, as concessões fechadas, os direitos de exclusividade e a obrigação de fornecimento cedem lugar a conceitos como sistema aberto, liberdade de entrada (mesmo havendo necessidade de autorização prévia e definidas obrigações de manutenção de serviço universal) e concorrência aberta (GROTTI, 2002).

O novo modelo de regulação para a competição tem em sua estrutura o conceito de unbundling, ou desintegração vertical das fases das atividades que estão sendo transferidas aos particulares. Isso porque cabe distinguir entre as necessidades de infra-estrutura para prestação do serviço e o serviço propriamente dito. A infra-estrutura deve ser compartilhada entre os entes prestadores do serviço (comuns) para que se possa garantir o acesso de todos os competidores potenciais ao serviço, e os serviços são prestados por diferentes operadoras em competição (singularizados).

Essas atividades de infra-estrutura têm natureza não-competitiva, sendo recomendável sua prestação em regime de concessão ou permissão. Têm essa natureza não-competitiva as atividades de instalação e gestão de infra-estrutura de uso comum e a prestação de serviços essenciais de forma universal, incluindo setores não lucrativos nos quais os competidores não se interessariam em concorrer.

Sobre a abertura de setores de serviços à livre competição, Grotti (2002) comenta que nesses setores há que se distinguir entre as atuações de caráter privado e as obrigações e encargos de serviço público, portanto de prestação continuada e universal. Há a eliminação do conceito de reserva de mercado, substituído pelo de atividade econômica regulada. O regime de prestação do serviço, até então fechado e exclusivo, passa a ser aberto à entrada de novos competidores (vinculada a entrada a uma autorização regulamentada) e com a imposição de encargos e obrigações de continuidade do serviço.

É o que ocorre na privatização do setor de telecomunicações.

\subsection{A Privatização do Setor de Telecomunicacões no Brasil}

O processo de privatização das telecomunicações no Brasil teve início com a Emenda Constitucional $\mathrm{n}^{\circ}$ 8, de 1995. Contudo, é necessário entender a privatização como um 
processo mais amplo, dentro de um contexto de desestatização na busca por maior eficiência na prestação de serviços públicos.

Di Pietro (1999) ensina que, na América Latina de modo geral (mais particularmente em países como Brasil, México, Chile, Bolívia, Argentina e Uruguai), o processo de privatização está sempre vinculado à idéia de reforma do Estado, com o objetivo de diminuir o seu tamanho.

Esse processo desenvolve-se:

[...] de um lado, prestigiando a liberdade econômica, pela devolução da iniciativa ao administrado, pela desregulamentação, pela eliminação de monopólios, pela aplicação das regras da livre concorrência, reservando-se ao Estado as tarefas de incentivar e subsidiar aquela iniciativa, quando deficiente, bem como a de fiscalizála, para proteger o usuário e o consumidor e resolver os respectivos conflitos; de outro lado, buscando a eficiência nos serviços afetos ao Estado, pela aplicação de novas técnicas de prestação de serviços, menos formalistas, menos burocratizadas, reservando-se o regime publicístico para os serviços públicos típicos do Estado, e aplicando-se os métodos de gestão privada para as atividades em que a rigidez do regime publicístico se torna desnecessária (como ocorre com os serviços sociais, comerciais e industriais do Estado); isto se dá pela venda de ações de empresas estatais ao setor privado e pelas várias formas de parceria com a iniciativa privada, em especial a concessão de serviço público, para desempenho de atividades antes executadas pelo próprio poder público, diretamente, ou pelas entidades da administração indireta (DI PIETRO, 1999, p.27).

A Constituição Federal, promulgada em 1988, ainda previa o monopólio estatal das telecomunicações. O artigo 21, incisos XI e XII, da Carta Magna, somente foram alterados pela Emenda Constitucional no 8, de 15 de agosto de 1995.

\footnotetext{
Art. 21 Compete à União:

$[\ldots]$

XI - explorar, diretamente ou mediante autorização, concessão ou permissão, os serviços de telecomunicações, nos termos da lei, que disporá sobre a organização dos serviços, a criação de um órgão regulador e outros aspectos institucionais; XII - explorar, diretamente ou mediante autorização, concessão ou permissão:

a) os serviços de radiodifusão sonora e de sons e imagens; $[\ldots]$.
}

Com a quebra do monopólio do Sistema Telebrás, foram editadas três leis fundamentais para a continuidade do processo de flexibilização das telecomunicações: a Lei 9.295, de 16 de julho de 1996, conhecida como Lei Mínima de Telecomunicações, autorizando a outorga de novas concessões do Serviço Móvel Celular; a Lei 8.987, de 13 de fevereiro de 1995, chamada Lei de Concessões de Serviços Públicos em Geral; e a Lei 8.977, de 06 de maio de 1995, a Lei de TV a Cabo.

O Estado, então, baseado no modelo de competição e universalização, transferiu para a iniciativa privada o controle acionário das empresas de telecomunicações, mantendo o 
controle da prestação do serviço pela regulamentação.

Em 16 de julho de 1997, foi promulgada a Lei Geral de Telecomunicações (Lei 9.472), criando a ANATEL - Agência Nacional de Telecomunicações, um órgão regulador, independente e autônomo, ao qual compete a regulamentação e fiscalização do setor de telecomunicações, além da mediação entre governo, empresas e sociedade/usuários.

Ventura (2001) explica que, com relação à exploração dos serviços de telecomunicações, há dois regimes jurídicos possíveis, nos termos da Lei Geral de Telecomunicações: o público, que deve obedecer aos princípios dos serviços públicos, como universalização e continuidade, tendo existência assegurada pelo Poder Público; e o privado, regido pelos princípios constitucionais de exploração de atividades econômicas.

E continua afirmando a importância da distinção entre serviço de interesse restrito (somente prestados em regime privado) e serviço de interesse coletivo (que pode ser prestado tanto em regime privado quanto público).

Quando a exploração ocorre no regime público, faz-se necessária outorga mediante concessão por parte da ANATEL. Quando é em regime privado, a outorga se dá mediante autorização.

As empresas privadas que monopolizaram os serviços de telefonia fixa em cada região, em regime público, ficaram, então, responsáveis pelo cumprimento dos deveres de universalização e continuidade do serviço de telecomunicações (chamadas concessionárias). Os novos concorrentes, chamados empresas-espelho, se sujeitaram ao regime privado.

\section{Serviço de telecomunicações em regime público é o prestado mediante concessão ou permissão, com atribuição à sua prestadora de obrigações de universalização e de continuidade. O serviço de telecomunicações em regime privado é o prestado mediante prévia autorização da ANATEL e será baseado nos princípios constitucionais da atividade econômica (GROTTI, 2002, p.68).}

A principal diferença entre os dois regimes está na relação entre a prestadora e o poder público, pois a autorizada não tem um contrato celebrado com o poder público, somente uma autorização e, assim, não tem dever de continuidade na prestação e nem de universalização dos serviços, do mesmo modo que não tem o direito de manutenção do equilíbrio econômico e financeiro, o direito de exploração dos serviços é por prazo indeterminado e os preços são livres (GROTTI, 2002).

Para exercer seu papel de órgão regulador das telecomunicações, a ANATEL dispõe de cinco instrumentos fundamentais no serviço telefônico fixo comutado (STFC): o Plano Geral de Outorgas (PGO), o Plano de Metas de Universalização (PGMU), o Plano de Metas de Qualidade (PGMQ), os contratos de concessão e os regulamentos de interconexão e de 
remuneração de redes.

O Decreto $\mathrm{n}^{\circ} 2.592 / 98$, que instituiu o PGMU, será revogado a partir de $1^{\circ}$ de janeiro de 2006, quando passa a vigorar um novo Plano de Metas de Universalização para o STFC, aprovado em 27 de junho de 2003 (Decreto $n^{\circ}$ 4.769/03). As principais alterações aparecem nos capítulos II e III, que passam a tratar das metas a serem cumpridas pelas concessionárias a partir de janeiro de 2006 (metas de acesso individuais e coletivos). Há a inclusão do capítulo IV, com as metas para instalação de postos de serviços de telecomunicações ${ }^{3}$ a partir de 2007, do capítulo V, com as metas para postos de serviços em áreas rurais, também a partir de 2007, e o capítulo VI, com as metas de acesso individuais classe especial ${ }^{4}$, a partir de 2006.

O PGO dividiu o país em quatro regiões de concessão (área de atuação):

- Região I - Estados do Rio de Janeiro, Minas Gerais, Espírito Santo, Bahia, Sergipe, Alagoas, Pernambuco, Paraíba, Rio Grande do Norte, Ceará, Piauí, Maranhão, Pará, Amapá, Amazonas e Roraima;

- Região II - Distrito Federal e Estados do Rio Grande do Sul, Santa Catarina, Paraná, Mato Grosso do Sul, Mato Grosso, Goiás, Tocantins, Rondônia e Acre;

- Região III - Estado de São Paulo;

- Região IV - nacional.

Cada região está dividida em setores (área geográfica), com prestadoras mediante concessão definidas e outras empresas atuando na mesma área para ampliação da concorrência.

Quadro 1: Áreas de atuação e acionistas de empresas concessionárias e empresas-espelho no setor de telefonia fixa no Brasil

\footnotetext{
${ }^{3}$ Posto de Serviço de Telecomunicações (PST) é um conjunto de instalações de uso coletivo, mantido pela concessionária, dispondo de, pelo menos, telefone de uso público e terminal de acesso público, e possibilitando o atendimento pessoal do consumidor (artigo $3^{\circ}$, VIII, PGMU).

${ }^{4}$ Acesso Individual Classe Especial (AICE) tem por finalidade a progressiva universalização do acesso individualizado por meio de condições específicas para sua oferta, utilização, aplicação de tarifas, forma de pagamento, tratamento das chamadas, qualidade e função social (artigo $3^{\circ}$, I, PGMU).
} 


\begin{tabular}{|c|c|c|}
\hline Áreas de atuação & Empresas Concessionárias & Empresas-espelho \\
\hline Região I & $\begin{array}{l}\text { Tele Norte-Leste } \\
\text { Andrade Gutierrez } \\
\text { Inepar } \\
\text { BNDES Participações } \\
\text { Seguradoras do BB }\end{array}$ & $\begin{array}{l}\text { Cambrá } \\
\text { Bell Canadá } \\
\text { WLL (EUA) } \\
\text { Qualcomm } \\
\text { SLI Wireless } \\
\text { Vicunha }\end{array}$ \\
\hline Região II & $\begin{array}{l}\text { Tele Centro-Sul } \\
\text { Itália Telecom } \\
\text { Lightel/Algar } \\
\text { Opportunity } \\
\text { Splice }\end{array}$ & $\begin{array}{l}\qquad G V T \\
\text { Global Village (Holanda) } \\
\text { ComTech (EUA) } \\
\text { RSL (EUA) }\end{array}$ \\
\hline Região III & \begin{tabular}{l}
\multicolumn{1}{c}{ Telesp } \\
Telefónica (Espanha) \\
Iberdrola (Espanha) \\
Banco Bilbao (Espanha)
\end{tabular} & \begin{tabular}{l}
\multicolumn{1}{c}{ Vésper } \\
Bell Canadá \\
WLL (EUA) \\
Qualcomm \\
Grupo Liberman (Argentina)
\end{tabular} \\
\hline Região IV & $\begin{array}{l}\text { Embratel } \\
\text { MCI (EUA) }\end{array}$ & $\begin{array}{l}\text { Intelig } \\
\text { Sprint (EUA) } \\
\text { France Telecom } \\
\text { National Grid }\end{array}$ \\
\hline
\end{tabular}

Fonte: VENTURA, 2001

O PGO estipula, ainda, que a prestação do serviço telefônico fixo comutado ocorrerá pelas concessionárias regionais e a nacional em âmbito intra-regional até 31 de dezembro de 2003, quando fica autorizada a liberação das concessionárias para a prestação de todo e qualquer serviço de telecomunicação. Contudo, o PGO também previa a possibilidade de essa liberação ocorrer já a partir de 01 de janeiro de 2002 caso as concessionárias conseguissem cumprir todas as metas de universalização previstas nos contratos de concessão.

Em 30 de julho de 1998 foi realizado o leilão das empresas do sistema TELEBRÁS. Findo o leilão, há o chamado período pós-privatização das telecomunicações.

O primeiro estágio deste período é a transição, que durou até 2002, caracterizando-se pela competição limitada e concentrada na telefonia interurbana.

O segundo estágio, de competição total, começa a se estruturar, e a presença de concessionárias que anteciparam o cumprimento de metas e receberem a liberação da agência reguladora atuando em outras regiões e oferecendo novos serviços já é uma realidade.

A liberação das concessionárias para a prestação de todos os serviços de telecomunicações a partir de 2002, prevista na Lei 9.472, de 16 de julho de 1997, antecipou, portanto, o aumento da concorrência, provocando conflitos entre as concessionárias e as novas empresas autorizadas.

A tarefa de organizar e mediar as relações entre essas operadoras de serviços de 
telecomunicações está entre as funções principais da agência reguladora do setor.

\title{
1.3 Agência Nacional de Telecomunicações - ANATEL
}

A ANATEL, ou Agência Nacional de Telecomunicações, foi criada pelo artigo $8^{\circ}$ da Lei n ${ }^{0} 9.472$ (Lei Geral de Telecomunicações), de 16 de julho de 1997, com a função de atuar como órgão regulador do setor de telecomunicações no Brasil.

Sundfeld (2002, p.18) afirma que

\begin{abstract}
a existência de agências reguladoras resulta da necessidade de o Estado influir na organização das relações econômicas de modo muito constante e profundo, com o emprego de instrumentos de autoridade, e do desejo de conferir, às autoridades incumbidas dessa intervenção, boa dose de autonomia frente à estrutura tradicional do poder político.
\end{abstract}

Tem regulamento próprio, aprovado pelo Decreto ${ }^{\circ} 2.338$, de 07 de outubro de 1997, e sede no Distrito Federal. É um órgão da administração pública federal indireta, submetida ao regime autárquico especial e vinculada ao Ministério das Comunicações. Por ter sido criada por lei, somente poderá ser extinta mediante a promulgação de outra lei específica.

Sua natureza de autarquia especial é caracterizada por independência administrativa, com ausência de subordinação hierárquica, mandato fixo e estabilidade de seus dirigentes, independência decisória, autonomia financeira, independência de objetivos e independência de instrumentos. Porém, como órgão público, está sujeita a controle estatal, devendo prestar contas nos aspectos qualitativos e financeiros de suas ações.

A independência administrativa reflete-se na ausência de subordinação hierárquica, ou seja, ela tem autonomia para compor, nomear e dispensar os membros de sua estrutura interna.

Ao regular as telecomunicações brasileiras, cabe à ANATEL exercer o poder concedente dos serviços públicos e a administração ordenadora das atividades privadas. Possui independência decisória para solucionar conflitos de interesses entre concessionárias e usuários, controlar as atividades realizadas no setor de telecomunicações e fiscalizar a política tarifária.

Como conseqüência da autonomia financeira, a ANATEL possui patrimônio e receitas próprios, devendo gerenciá-los.

A independência de objetivos está consubstanciada na possibilidade de definir seus próprios objetivos, sem colidir ou prejudicar a satisfação dos usuários dos serviços de 
telefonia.

A ANATEL pode escolher quais instrumentos de regulação do setor de telecomunicações são mais adequados para a consecução de seus objetivos (tarifas, planos etc), caracterizando sua independência de instrumentos.

A principal competência da ANATEL é a de implementação de uma política nacional de telecomunicações, devendo também adotar medidas para o atendimento do interesse público, bem como para o desenvolvimento tecnológico e social das telecomunicações do Brasil, atuando com independência, imparcialidade, legalidade, impessoalidade e publicidade.

Com relação à regulação da concorrência, é também papel da ANATEL garantir, na prática, o controle, prevenção e repressão de infrações da ordem econômica praticadas pelas empresas do setor de telecomunicações, instaurando processos administrativos para verificação desses casos e remetendo-os, então, ao CADE, definir condições e compromissos para evitar tais práticas e encaminhar ao CADE solicitações de empresas que possam, eventualmente, acarretar concentração econômica (como fusões e aquisições, por exemplo).

Assim, a ANATEL tem poderes para defender e garantir a competitividade no setor de telecomunicações, mas deve atuar de forma conjunta com o CADE, pois a esse cabe impor penalidades àqueles competidores que tiverem práticas anticompetitivas ou de domínio de mercado.

É a própria Lei Geral de Telecomunicações que garante a atuação do CADE no setor de telecomunicações ao prever, em seu artigo $7^{\circ}$, que as normas de proteção da ordem econômica são também aplicáveis a este setor (LEHFELD, 2001).

\subsection{Modelo de Privatização das Telecomunicações no Brasil}

Ventura (2001) explica que as empresas poderiam participar do leilão de privatização do Sistema Telebrás de forma isolada ou a partir de consórcios, mas desde que respeitados alguns limites: uma empresa que tivesse participação igual ou superior a vinte por cento na composição acionária de um consórcio não poderia adquirir mais de uma companhia de cada grupo $^{5}$; e uma mesma companhia não poderia adquirir uma companhia de telefonia fixa e outra de telefonia celular em uma mesma área de atuação. Não foi imposto limite à participação de capital estrangeiro, o que incentivou a entrada de grandes operadoras de

\footnotetext{
${ }^{5}$ Quando da realização do leilão, as empresas a serem privatizadas foram divididas em três grupos:

- grupo A: formado pelas três companhias de telefonia fixa local e regional e pela companhia de longa distância;

- grupo B: formado pelas quatro companhias de telefonia celular com maior valor de mercado;
} 
telefonia internacionais.

O modelo adotado para a privatização do setor de telecomunicações no Brasil é baseado nos conceitos de competição e universalização.

A competição pode ser caracterizada pela existência de empresas particulares distintas concorrendo pelos mesmos clientes concomitantemente. As regras de atuação para essas empresas são diferentes, dependendo do regime jurídico de prestação do serviço (concessão ou autorização), mas o acesso às instalações necessárias à prestação do serviço é garantido.

Por ser o setor de telecomunicações de grande relevância social, a prestação do serviço à comunidade deve estar disponível a todos e deve ser feita de forma contínua, o que significa que a agência reguladora, assim como o contrato de concessão, prevêem a obrigatoriedade de cumprimento de metas definidas pelo próprio poder público e que ditam as normas para adequação e expansão do serviço prestado.

As concessionárias têm prerrogativas e obrigações próprias de prestador de serviço público, enquanto as autorizadas têm maior liberdade de ação, mas, independente do regime jurídico, a concorrência entre elas ocorre de forma direta no setor de telecomunicações. E tal concorrência tende a se intensificar, atingindo a fase de competição total, quando as concessionárias recebem liberação para prestação de outros serviços e de atuação em outras regiões geográficas e, portanto, há livre competição entre as empresas privadas situadas no setor.

Justen Filho (2003, p.129) traz a relação entre concessão e privatização.

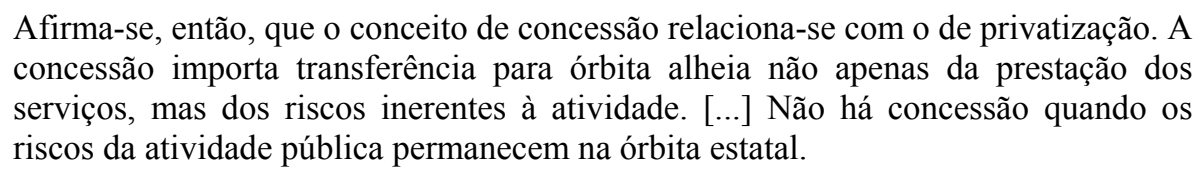

Importante, então, compreender a formação dos contratos administrativos em geral e dos contratos de concessão, em específico.

\section{$\underline{1.5 \text { Os Contratos Administrativos }}$}

O contrato é uma das fontes das obrigações. É um negócio jurídico bilateral ou

- grupo C: formado pelas quatro companhias de telefonia celular com menor valor de mercado. 
plurilateral, um ato jurídico regulamentador de interesses privados. É o acordo de vontades que tem por fim criar, modificar ou extinguir um direito.

O contrato é um acordo bilateral de vontades, que produz efeitos para aqueles que manifestaram a vontade e contrataram. O contrato não pertence ao ramo privado e nem ao público. Há contratos de direito público assim como há os de direito privado.

Os contratos particulares ou realizados sob o regime do direito privado podem ter, como partes contratantes, apenas particulares ou mesmo a administração pública e particular. Já os contratos administrativos são espécies de contratos realizados sob o regime do direito público, e pelo menos uma das partes (contratante) deve ser a administração pública, agindo nessa qualidade, ou seja, agindo com a supremacia do Poder Público.

Os doutrinadores divergem quanto à existência ou não de contratos administrativos. Para alguns, não estariam presentes as características essenciais dos contratos em geral, havendo somente atos unilaterais da Administração. Para outros, não há distinção entre os contratos da Administração e os contratos administrativos. A maioria, contudo, vê a existência desses dois tipos, pois a administração pública pode celebrar contratos sob o regime de direito privado ou sob o regime de direito público. Assim, "contrato administrativo é todo acordo de vontades de que participa a Administração e que, tendo por objetivo direto a satisfação de interesses coletivos, está submetido a um regime jurídico de direito público e informado por princípios publicísticos”(CRETELLA JUNIOR, 1998, p.141).

Nos dizeres de Meirelles (1998, p.188-189),

contrato administrativo é o ajuste que a administração pública, agindo nessa qualidade, firma com particular ou outra entidade administrativa para a consecução de objetivos de interesse público, nas condições estabelecidas pela própria Administração.

Independente de o contrato ser celebrado sob o regime de direito público, nos quais a Administração atua com supremacia sobre o particular, ou sob o regime do direito privado, nos quais a Administração se sujeita aos princípios do direito privado, a Administração não pode comportar-se como o particular e escolher livremente a outra parte com quem quer contratar. Para prevalecer e não prejudicar o interesse público (coletivo), a Administração sujeita-se à escolha do melhor contratante, aquele com a melhor proposta: surge a figura da licitação.

Quando se fala em contratos administrativos, necessário se faz que uma das partes (mais precisamente o contratante) seja a administração pública, direta (União, Estados, Municípios ou Distrito Federal) ou indireta (autarquias, fundações públicas, sociedades de 
economia mista). A outra parte (contratada) poderá ser um particular, ou seja, pessoa física ou jurídica, de natureza mercantil, industrial ou prestador de serviços, ou mesmo outro órgão ou entidade da própria administração pública.

Em qualquer caso, é necessário que as partes estejam devidamente representadas. No caso da administração pública, a representação compete a quem a lei atribui essa competência, e no caso de empresa privada contratada a atribuição é dada pelo contrato social de formação da pessoa jurídica ou por deliberação da Assembléia Geral.

Para que se esteja realmente diante de um contrato administrativo, alguns requisitos e caracteres tornam-se imprescindíveis.

O primeiro deles é a presença da administração pública agindo nessa qualidade, ou seja, agindo com a supremacia do Poder Público. Ora, para que se tenha contrato administrativo é preciso que o contrato seja celebrado sob o regime de direito público, com a Administração se sobrepondo sobre o particular (ou melhor, sobre a outra parte contratante) a fim de alcançar a consecução do interesse coletivo.

Disso decorre a segunda característica, a finalidade pública, que deve estar presente nos contratos administrativos, mas também nos atos e nos contratos sob o regime do direito privado.

A obediência à forma prescrita em lei é outra característica dos contratos administrativos. Em geral, os contratos são escritos (salvo no caso de compras de pequeno valor com pagamento imediato), formalizados pelo termo de contrato, pela nota de empenho de despesa, pela carta-contrato, pela autorização de compra, pela ordem de execução de serviço ou mediante escritura pública lavrada em cartório, nos casos de direitos reais sobre imóveis.

O procedimento legal refere-se às exigências da lei para que determinada modalidade de contrato administrativo seja celebrada. Dentre esses procedimentos obrigatórios encontrase a licitação.

A natureza de contrato de adesão está presente porque é a Administração que estipula as cláusulas do contrato, cabendo à outra parte aceitar ou não as condições determinadas por ela. Mesmo quando não há licitação cabe à Administração estabelecer essas cláusulas, pois nos contratos administrativos age com a supremacia do Poder Público. Quando há licitação, a Administração declara sua vontade e suas condições para contratar e os interessados manifestam suas possibilidades de atender a essas exigências, cabendo à Administração escolher a melhor proposta. 
Quando há licitação, os contratos têm natureza intuitu personae, pois a Administração escolhe um licitante e com ele contrata, tornando-se impossível a substituição desse contratante ou mesmo a subcontratação total ou parcial do objeto do contrato.

As cláusulas exorbitantes são aquelas que colocam a Administração num patamar de supremacia frente ao outro contratante, mas que se estivessem presentes em um contrato particular seriam nulas por conceder muitos privilégios a uma parte em prejuízo da outra.

A mutabilidade, por sua vez, decorre dessas cláusulas exorbitantes, permitindo à Administração alterar unilateralmente disposições contratualmente avençadas.

Há várias espécies ou modalidades de contratos administrativos. Os principais são o contrato de obra pública, o de fornecimento, o de serviço e o de concessão, com suas várias espécies próprias.

Nos contratos entre particulares prevalece a autonomia da vontade, destinada à escolha ou não da contratação, de seu objeto e da outra parte contraente. Nos contratos administrativos, contudo, a regra é a da exigência da licitação prévia para a contratação, pois cabe a ela apontar aquele que melhor atende aos interesses públicos, aquele que deve ser o contraente da obrigação perante a Administração.

Licitação é o procedimento de direito público, geral e impessoal, empregado pela Administração direta ou indireta, para a seleção da melhor proposta, dentre as apresentadas pelos administrados, que pretendem celebrar com o Estado contratos de compra e venda, de execução de obras públicas ou a gestão de um serviço público (CRETELLA JUNIOR, 1998, p.144).

As modalidades de licitação previstas no direito brasileiro são: concorrência, tomada de preços, convite, concurso e leilão.

Concorrência é a modalidade utilizada pela Administração nos casos de compras, obras ou serviços de vulto, em que se admite a participação de qualquer licitante através de convocação ampla.

Tomada de preços é a modalidade de licitação entre interessados previamente registrados, já habilitados.

Convite é para os interessados no ramo pertinente ao objeto da licitação, em número mínimo de três, escolhidos pela Administração, registrados ou não, e convocados por escrito com antecedência mínima de três dias úteis.

Concurso é a modalidade voltada para a escolha de projetos técnicos e artísticos, atribuindo-se prêmios (e não preços) aos vencedores. Como se trata apenas de projetos, a execução dos trabalhos depende, geralmente, de nova licitação, para a escolha de quem o 
realize.

Leilão é a modalidade utilizada em casos de alienações efetuadas pela Administração. Essa é a modalidade adotada para a privatização do setor de telecomunicações no Brasil. Escolhidos os grupos particulares no leilão de privatização (concessionárias), foram celebrados contratos de concessão entre a administração pública e as operadoras em regime público.

\section{$\underline{\text { 1.5.1 Contratos de Concessão }}$}

O contrato de concessão é aquele mediante o qual a Administração delega a particular ou a entidade ou órgão da própria Administração a execução de serviço ou obra pública ou cede-lhe o uso de bem público.

Os contratos de concessão são considerados os contratos administrativos por excelência, pois apresentam claramente os aspectos característicos e peculiares destes contratos. São, como todos os contratos administrativos, bilaterais, comutativos, onerosos, formais e realizados intuitu personae.

Contrato de concessão é o ajuste pelo qual a administração pública delega ao particular a execução remunerada de serviço ou de obra pública ou lhe cede o uso de um bem público, para que o explore por sua conta e risco, pelo prazo e nas condições regulamentares e contratuais (MEIRELLES, 1998, p.231).

Dessa definição apreende-se que pelo contrato de concessão a administração pública concede a particular a execução de serviço ou obra pública ou cede o uso de bem público. Surgem as três modalidades de concessão: concessão de serviço público, concessão de obra pública e concessão de uso de bem público.

O contrato de concessão de serviço público é aquele

[...] pelo qual a administração pública delega a outrem a execução de um serviço público, para que o execute em seu próprio nome, por sua conta e risco, assegurando-lhe a remuneração mediante tarifa paga pelo usuário ou outra forma de remuneração decorrente da exploração do serviço (DI PIETRO, 1998, p.243).

Trata-se de um serviço próprio do Poder Público, estabelecido em lei como sendo uma atividade que compete ao Estado oferecer aos seus cidadãos, seja diretamente ou mediante concessão ou permissão.

A administração pública transfere a particular ou a órgão ou entidade da própria Administração a prestação desse serviço, mas continua sendo a responsável por ele, ou seja, 
compete-lhe fiscalizar a adequada prestação do serviço e também reivindicar a retomada da prestação do serviço a qualquer tempo, mediante indenização (isso significa que a Administração pode conceder a prestação do serviço a outrem e depois resolver voltar a prestar o serviço diretamente, se isto for mais conveniente ao interesse comum).

Como o concessionário executa o serviço por sua própria conta e risco, o pagamento é recebido mediante tarifa, ou seja, ele presta o serviço e aqueles que o usarem pagam uma certa quantia, já estabelecida anteriormente pelo Poder Público no próprio contrato de concessão. Aqui reside a diferença entre taxa e tarifa: enquanto aquela é devida por todos, esta é cobrada apenas daqueles que efetivamente usam o serviço.

A privatização do setor de telecomunicações adotou essa modalidade de contrato administrativo para definir os parâmetros de atuação das empresas concessionárias do serviço telefônico fixo comutado. Cabe aos contratos de concessão delimitar os direitos e deveres das operadoras de telefonia, incluindo, também, os indicadores do Plano Geral de Metas de Qualidade do Plano Geral de Metas de Universalização.

\subsubsection{Os Contratos de Concessão no Setor de Telecomunicacões}

A Lei Geral de Telecomunicações definiu que a delegação da prestação dos serviços de telecomunicações na modalidade de concessão seria feita mediante a celebração de um contrato entre o poder público e o particular. À empresa concessionária caberiam os riscos do empreendimento, que seria remunerado pela cobrança de tarifas dos usuários.

Ventura (2001) esclarece que ao celebrar esses contratos de concessão, o poder público devia seguir as diretrizes definidas no Plano Geral de Outorgas, buscando maximizar o benefício do usuário e prevalecendo os interesses econômicos e sociais do país.

Nos contratos administrativos em geral, há prevalência do interesse público sobre o particular, tendo a Administração supremacia sobre o outro contratante. No caso dos contratos de concessão do setor de telecomunicações, entretanto, tem-se que os grupos vencedores do leilão detêm grande poder econômico e político, fazendo com que esses contratos tivessem que ser celebrados enumerando o maior número possível de situações, como direitos e obrigações da concessionária e o rigoroso cumprimento das metas de qualidade e universalização (VENTURA, 2001).

Apesar da previsão na Lei Geral de Telecomunicações de regras próprias para as delegações de serviços desse setor (concessão, permissão e autorização), os contratos de 
concessão de telecomunicações contemplam todas as exigências dos contratos de concessão em geral ${ }^{6}$.

Em 27 de maio de 1998 a Resolução no 36 da ANATEL aprovou os modelos de contratos de concessão para prestação em regime público de serviço telefônico fixo comutado nas modalidades de chamadas locais e chamadas de longa distância nacional e internacional.

Em 2003 esses contratos de concessão foram renovados, com alterações em suas cláusulas e com vigência definida de 2006 a 2025.

Os contratos de concessão em vigor prevêem a manutenção do equilíbrio econômicofinanceiro das concessionárias, mas definem a não existência de qualquer reserva de mercado ou monopólio. As concessionárias ficam sujeitas aos princípios de prestação de serviço público e devem cumprir metas de qualidade e universalização. Em contrapartida, receberam as estruturas anteriormente utilizadas pelas empresas estatais. Assim, os contratos de concessão do setor de telecomunicações seguem a previsão do modelo de privatização, baseado em universalização de serviços e competição.

A competição, na fase de transição, ocorre em regime de duopólio, com a atuação da empresa concessionária e da empresa-espelho. Na fase de competição, o modelo prevê a existência de mais de dois competidores (em regime de autorização, ou seja, além da concessionária).

Depreende-se, então, que a desestatização do setor de telecomunicações ocorre concomitantemente ao início da competição entre as prestadoras de serviço do setor (SUNDFELD, 2002, p.35).

Portanto, a reforma não se limitou à mera venda de empresas para o setor privado,

\footnotetext{
6 “Artigo 93 - O contrato de concessão indicará:

I - objeto, área e prazo da concessão;

II - modo, forma e condições da prestação do serviço;

III - regras, critérios, indicadores, fórmulas e parâmetros definidores da implantação, expansão, alteração e modernização do serviço, bem como de sua qualidade;

IV - deveres relativos à universalização e à continuidade do serviço;

$\mathrm{V}$ - o valor devido pela outorga, a forma e as condições de pagamento;

VI - as condições de prorrogação, incluindo os critérios para fixação do valor;

VII - as tarifas a serem cobradas dos usuários e os critérios para seu reajuste e revisão;

VIII - as possíveis receitas alternativas, complementares ou acessórias, bem como as provenientes de projetos associados;

IX - os direitos, as garantias e as obrigações dos usuários, da Agência e da concessionária;

$\mathrm{X}$ - a forma da prestação de contas e físcalização;

$\mathrm{XI}$ - os bens reversíveis, se houver;

XII - as condições gerais para interconexão;

XIII - a obrigação de manter, durante a execução do contrato, todas as condições de habilitação exigidas na licitação;

XIV - as sanções;

XV - o foro e o modo para solução extrajudicial das divergências contratuais" (Lei nº 9.472/97).
} 
mas veio acompanhada da abertura dos respectivos mercados para novas prestadoras. E qual a justificativa do modelo? É a de que a concorrência seria boa tanto para o desenvolvimento econômico, porque apressaria a expansão da planta de serviços, como para o consumidor, pois geraria disputa, com melhoria de preços e serviços.

Deve-se analisar os principais conceitos de concorrência e competitividade para justificar a adoção desse modelo de privatização no setor de telecomunicações. A intensificação da concorrência deve proporcionar melhoras no serviço e redução de tarifas à medida que se torna necessário conquistar e disputar o usuário e este, por sua vez, tem seu poder de negociação frente às empresas de telefonia aumentado, já que possui opções de escolha de outras prestadoras. 


\section{CAPÍTULO II}

\section{Concorrência e competitividade: aspectos gerais}

A análise da concorrência envolve questões relacionadas ao ambiente no qual uma empresa está inserida e a indústria ou setor no qual ela compete. Porter define "indústria como o grupo de empresas fabricantes de produtos que são substitutos bastante aproximados entre si” (PORTER,1997, p.24).

A concorrência funciona como um fator de diminuição do retorno sobre o capital investido dentro de uma indústria. Em situações de concorrência perfeita (ou livre mercado), o retorno tende a ser igual ou superior ao retorno propiciado pela aplicação em títulos do governo (sem risco). Neste contexto, as empresas não aceitam continuar no mercado caso o retorno seja inferior ao daqueles títulos. Contudo, mercados que apresentam retorno maior que aquele definido para o livre mercado tendem a atrair mais investimentos, seja de outras empresas (novos concorrentes) ou das empresas já situadas no mercado, mas que desejam expandir suas atividades.

O grau da concorrência em uma indústria depende, na definição de Porter (1997), de cinco forças competitivas básicas:

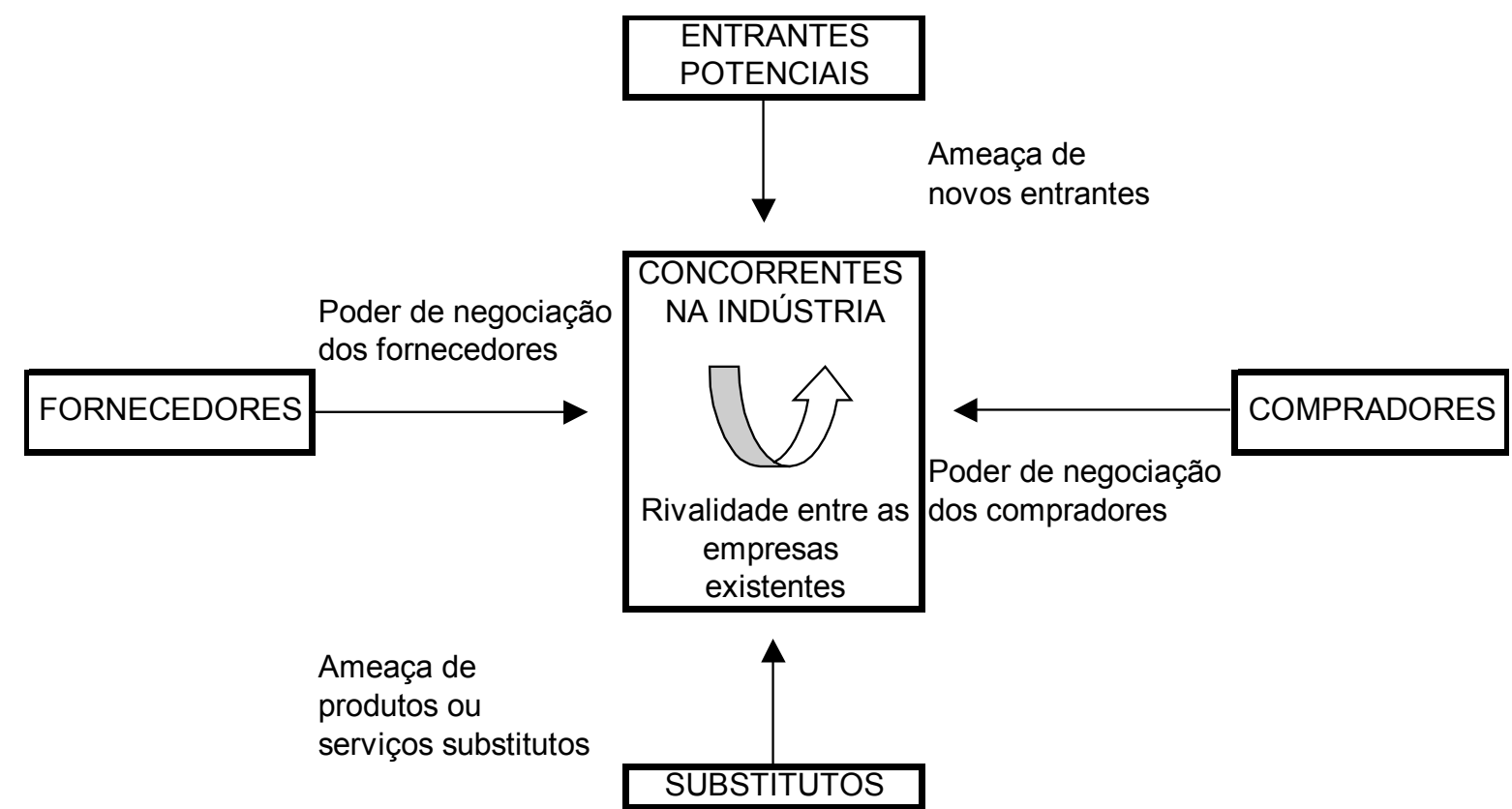


Figura 1: As cinco forças competitivas de Porter Fonte: PORTER (1997)

O conjunto dessas cinco forças determina o potencial de lucro na indústria e, como as forças (mais precisamente sua incidência ou capacidade de influência) diferem de uma indústria para outra, o mesmo ocorre com o potencial de lucro de diferentes indústrias.

A partir da figura acima é possível visualizar que a concorrência não se limita às outras empresas já situadas na indústria. É um conceito ampliado de concorrência, uma vez que todos esses outros fatores são considerados como concorrentes, com maior ou menor influência, da empresa, ou, nos dizeres de Porter (1997), concorrência passa a ser sinônimo de "rivalidade ampliada".

Gianesi e Corrêa (1994, p.54) utilizam o modelo de Porter (1997) para verificar o grau (ou poder) de competitividade de empresas que atuam no setor de serviços, definindo que

ter poder de competitividade significa ser capaz de minimizar as ameaças de empresas ingressantes no mercado ou de serviços substitutos, vencer a rivalidade imposta por empresas concorrentes, ganhando e mantendo fatias do mercado, assim como ser capaz de reduzir o poder de barganha de fornecedores e consumidores.

\section{$\underline{\text { 2.1 Ameaça de Entrada }}$}

A ameaça de novos entrantes demonstra a importância dos novos concorrentes, chamados de entrantes potenciais, e que representam empresas (grupos) interessados em competir na indústria principalmente em função de retornos elevados ou previsão de crescimento de demanda. Os novos entrantes alteram a situação da indústria, muitas vezes reduzindo custos e preços e, conseqüentemente, lucro e rentabilidade, trazendo novas tecnologias, mais recursos e conquistando participação de mercado.

A intensidade da ameaça de entrada depende das barreiras de entrada presentes na indústria e das possíveis reações dos concorrentes já estabelecidos.

São basicamente sete barreiras principais (PORTER, 1997):

a) economias de escala, ou seja, redução nos custos conseguida pelo aumento da quantidade produzida, o que significa que a nova empresa deve optar entre produzir já inicialmente uma grande quantidade e arriscar-se no mercado, inclusive podendo sofrer forte retaliação dos concorrentes já estabelecidos, ou ter uma produção em pequena escala e assumir a elevação dos custos;

b) diferenciação do produto, uma barreira crucial nos casos das indústrias em que as 
empresas já estabelecidas têm marca e ligação com os clientes fortes, gerando necessidade de maiores investimentos do novo entrante para tentar consolidar sua posição;

c) necessidades de capital, já que algumas indústrias têm características peculiares de requerem altos investimentos em estrutura física, tecnologia ou pesquisa e desenvolvimento que podem não ter o retorno esperado (especialmente no curto prazo);

d) custos de mudança referem-se à posição dos clientes, que podem ter que investir ou gastar mais recursos para substituir as marcas já utilizadas por uma nova entrante, fazendo com que o potencial concorrente tenha que, de alguma forma, compensar esse gasto extra na mudança;

e) acesso aos canais de distribuição é fundamental para que a empresa possa fazer com que seu produto chegue ao cliente. Assim, o novo entrante terá que conseguir acesso a algum dos canais já existentes ou buscar novas alternativas para distribuição de seus produtos;

f) desvantagens de custo, independentes da escala, já que as empresas já estabelecidas no mercado possivelmente têm a vantagem de custos menores em função das curvas de experiência e aprendizagem, tecnologias exclusivas, acesso a matérias-primas, entre outros;

g) política governamental é considerada uma barreira porque o governo pode limitar o acesso de um novo concorrente a alguns mercados, por meio da concessão de licenças, ou mesmo ter papel regulador em alguns, visando garantir o rigoroso atendimento de necessidades da comunidade.

A previsão de reação dos concorrentes já estabelecidos influencia, também, a decisão de entrar ou não no mercado, pois há a ameaça de retaliações, respostas duras que podem tornar insustentável a permanência do concorrente no mercado.

Especificamente no caso do setor de serviços, as empresas podem criar barreiras de entrada ao conseguirem ter técnicas de gestão diferenciadas e específicas para seu ramo de atuação, sendo, portanto, mais eficientes que os concorrentes do setor, assim como podem conseguir diferenciação de seus serviços por meio da obtenção de um nível de qualidade na prestação do serviço percebido e reconhecido pelos clientes.

Ao utilizar estratégias de fidelização ou mesmo oferecendo vantagens àqueles que mantêm certa regularidade de aquisição do serviço oferecido, a empresa pode estar, na 
verdade, conseguindo estabelecer custos de mudança (ou troca) para o cliente. A formação de redes de distribuição do serviço também é uma forma de se conseguir vantagem competitiva sobre potenciais novos concorrentes, até pela facilidade e comodidade oferecida ao cliente.

Por fim, quanto maior o tempo de atuação da empresa no setor, mais experiência na prestação do serviço e conhecimento sobre as atividades, desejos, necessidades e expectativas do cliente daquele ramo de atividade ela deve possuir. Somando-se a isso os investimentos tecnológicos para melhoria do atendimento e armazenamento de dados dos clientes, tem-se uma forte barreira à entrada de novos concorrentes (GIANESI, CORRÊA, 1994).

\section{$\underline{\text { 2.2 Intensidade da Rivalidade entre os Concorrentes Existentes }}$}

"A rivalidade entre os concorrentes assume a forma usual de manobras pelo posicionamento - a utilização de táticas como competição no preço, introdução de produtos e combates publicitários" (PORTER, 1999, p.39). A intensidade dessa rivalidade depende de alguns fatores estruturais:

a) concorrentes numerosos e/ou bem equilibrados em termos de tamanho e poder;

b) crescimento lento da indústria, o que acarreta disputas acirradas pela participação de mercado, especialmente para as empresas que buscam expansão;

c) ausência de diferenciação ou de custos de mudança, dificultando a retenção e fidelização do cliente;

d) custos fixos ou de armazenamento altos, induzindo a uma redução dos preços para estimular a venda;

e) capacidade aumentada em grandes incrementos para se ter economia de escala, rompendo o equilíbrio entre oferta e demanda e acarretando redução de preços;

f) concorrentes divergentes em termos de estratégias, origens e idéias sobre competição, dificultando a interpretação das intenções desses concorrentes;

g) barreiras de saída são fatores econômicos, estratégicos e emocionais que fazem com que as empresas continuem competindo em determinada indústria apesar de não estarem conseguindo retornos adequados sobre seus investimentos. Quando essas barreiras são elevadas, há excesso de capacidade (oferta) no mercado e como as empresas continuam competindo mesmo estando com resultados insatisfatórios, a rentabilidade da indústria como um todo é afetada. 
um determinado negócio, prolongam a atuação da empresa no setor, mesmo que ela esteja obtendo retornos muito baixos ou negativos sobre o investimento. A situação prolonga indefinidamente o excesso de capacidade e a rentabilidade dos concorrentes saudáveis sofre as conseqüências, enquanto as empresas enfermas permanecem no setor (PORTER, 1999, p.39).

Gianesi e Corrêa (1994, p.62) afirmam que a vantagem competitiva sustentável para as empresas do setor de serviços deve ser conseguida basicamente a partir da excelência nas operações.

\begin{abstract}
As estratégias de competição devem, então, ser baseadas na diferenciação, no aumento na qualidade do serviço prestado, e na criação de switching costs, principalmente baseados em lealdade dos consumidores a um serviço excelente. $\mathrm{O}$ sucesso destas estratégias depende basicamente do desempenho da função de operações.

À parte outras estratégias, [...], fica claro que as operações têm muito a contribuir para o desenvolvimento de vantagens competitivas e, o que é mais importante, não somente através da redução dos custos incorridos na geração e prestação dos serviços. Mais do que isso, vantagens competitivas de longo prazo são conseguidas através de qualidade nos serviços prestados, ou seja, da satisfação do consumidor.
\end{abstract}

\title{
2.3 Pressão dos Produtos Substitutos
}

Os produtos substitutos são identificados a partir da verificação da existência no mercado de outros produtos que desempenham a mesma função que um determinado produto.

Por imporem um teto aos preços, os produtos ou serviços substitutos limitam o potencial de um setor. A não ser que consiga melhorar a qualidade do produto ou, de alguma forma (através do marketing) estabelecer uma diferenciação, o setor sofrerá as conseqüências nos lucros e, possivelmente, no crescimento. É inquestionável que, quanto mais atrativa for a opção excludente preço-desempenho oferecida pelos produtos substitutos, mais rígidos serão os limites impostos ao potencial do setor (PORTER, 1999, p.38).

Para Gianesi e Corrêa (1994, p.57) "serviços substitutos são aqueles que procuram atender à parte fundamental do conjunto de necessidades dos consumidores, constituindo, entretanto, serviços diferentes daqueles da indústria em questão".

Novamente a forma de reação à atuação dos substitutos é buscar a excelência na prestação do serviço, principalmente em fatores valorizados pelo cliente-alvo, mas não oferecidos pelo substituto (GIANESI, CORREAA, 1994).

\subsection{Poder de Negociação dos Compradores}


Os compradores devem ser considerados como concorrentes porque pressionam as empresas por preços menores, maior qualidade ou mais serviços agregados ao produto, além de incentivar a competição acirrada entre as empresas de uma indústria para conquistar parcelas de mercado, reduzindo a rentabilidade da indústria como um todo.

A importância dos compradores em determinada indústria depende de uma série de fatores, como quantidade de compra, importância relativa de sua situação atual de compra para a indústria, situação de alta padronização dos produtos adquiridos, poucos (ou inexistentes) custos de mudança, comprador com alto índice de informação sobre o produto e a indústria, entre outros.

Para reduzir o poder de barganha de consumidores finais no setor de serviços é preciso oferecer serviços diferenciados e garantir a satisfação do consumidor, pois um fator de escolha importante neste setor é o depoimento de clientes anteriores sobre a qualidade do serviço (GIANESI, CORRÊA, 1994).

\subsection{Poder de Negociação dos Fornecedores}

Esse poder é refletido nas possibilidades de elevação dos custos ou redução da qualidade do material fornecido. É capaz de reduzir a rentabilidade de indústrias nas quais não se consegue repassar aumentos de custos aos preços finais dos produtos.

Os fornecedores têm seu poder aumentado quando, em seu mercado de atuação, há poucos concorrentes e inexistem produtos substitutos; a empresa que adquire seus produtos não é seu cliente mais significativo, mas seu insumo é crucial para o negócio do cliente; há custos de mudança elevados ou a marca é forte ou mesmo há diferenciação percebida do seu produto em relação ao dos concorrentes.

Para o setor de serviços, podem ser adotadas estratégias de integração vertical regressiva ou diminuição de custos de mudança para se conseguir a redução do poder de barganha dos fornecedores (GIANESI, CORRÊA, 1994).

Para enfrentar essas cinco forças competitivas, as empresas dispõem, basicamente, de três abordagens estratégicas genéricas (PORTER, 1997):

1. liderança no custo total;

2. diferenciação;

3. foco. 
"A estratégia competitiva envolve o posicionamento de um negócio de modo a maximizar o valor das características que o distinguem de seus concorrentes" (PORTER, 1997, p.61). Assim, para a formulação de uma adequada estratégia competitiva, é fundamental uma análise detalhada da concorrência, de modo a possibilitar o conhecimento das estratégias atuais e futuras dos concorrentes, das possíveis reações a alterações na indústria e nos concorrentes, etc. Há quatro componentes diagnósticos para uma análise da concorrência: metas futuras, estratégia em curso, hipóteses (sobre a própria empresa e sobre a indústria) e capacidades (pontos fortes e fracos). A análise conjunta dos quatro componentes permite a definição do perfil de respostas do concorrente (PORTER, 1997).

a) metas futuras: indica a análise sobre o que orienta o concorrente, ou seja, o grau de satisfação atual do concorrente com seus resultados, possibilitando prever eventuais alterações de estratégia e as reações a mudanças na indústria ou a estratégias diversificadas dos concorrentes;

b) hipóteses: é a análise das hipóteses que o concorrente faz sobre si mesmo e sobre a indústria, isto é, sobre as demais empresas que dela participam.

c) estratégia em curso: questiona o que o concorrente está fazendo (estratégia atual) e o que ele pode fazer;

d) capacidades: identificação tanto dos pontos fortes como dos pontos fracos dos concorrentes visando definir a capacidade do concorrente de reação a alterações no ambiente e de iniciar novos movimentos na indústria (mudança estratégica).

Esses aspectos devem ser analisados em função de todos os concorrentes já estabelecidos na indústria e também em relação a possíveis novos entrantes e considerando a possibilidade de fusões e aquisições dentro da indústria.

A indústria em estudo é o setor de telecomunicações no Brasil, enfatizando o STFC (Serviço Telefônico Fixo Comutado).

Partindo da Figura 1 (As cinco forças competitivas de Porter), é possível estabelecer o seguinte cenário:

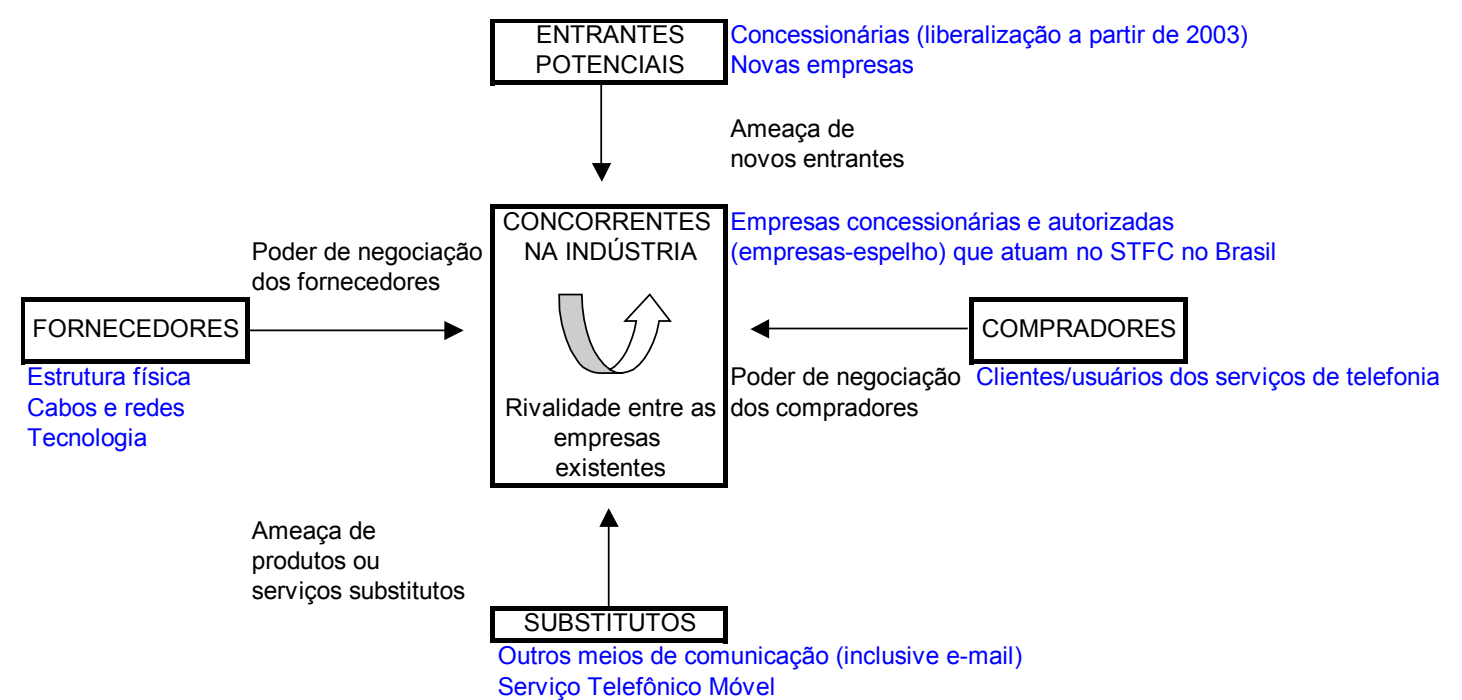


Figura 2: As cinco forças competitivas de Porter para o setor de telecomunicações no Brasil Fonte: autora, a partir de PORTER (1997)

Analisando as cinco forças para o caso estudado no presente trabalho, tem-se como concorrentes na indústria as empresas atuantes no serviço de telefonia fixa para a prestação de serviços de longa distância nacional e internacional. A empresa concessionária desses serviços é a Embratel, e a empresa-espelho, que atua no regime de autorização, é a Intelig ${ }^{7}$.

Como entrantes potenciais tem-se as empresas que são concessionárias de serviços de telecomunicações em âmbito local e que anteciparam o cumprimento das metas definidas no Plano de Outorgas para o ano de 2002. É o caso da Telefônica.

Os serviços substitutos são definidos como as outras formas possíveis de comunicação a disposição do usuário que preferir não utilizar o serviço de chamada telefônica de longa distância: o uso de e-mail ou carta pode ser utilizado como exemplo de substituto.

Os compradores são os usuários do serviço de telefonia. São eles que devem ter, na visão de concorrência institucional de Salomão Filho (2002), a liberdade de escolha da empresa prestadora de serviço.

E, como fornecedores, pode-se considerar empresas de fornecimento de cabos, redes e equipamentos, além da estrutura física necessária à operacionalização do serviço. Cabe relembrar que é comum concorrentes do setor de telecomunicações serem também fornecedores da estrutura que viabiliza a operação de outras empresas: é caso dos contratos de remuneração de redes.

Por não ser foco do estudo analisar a cadeia do setor de telecomunicações, são desconsiderados para efeitos de análise os aspectos concernentes a fornecedores, usuários e substitutos do serviço de telefonia. Concentra-se a análise nas relações entre os concorrentes do setor após a privatização, mais especificamente nos conflitos surgidos no período pósprivatização, incluindo, portanto, os entrantes potenciais, e enfatizando a prestação de serviços telefônicos para chamadas de longa distância e internacional.

Grotti (2002, p.62-63) traz as características do regime jurídico de atividades competitivas ao tratar do novo modelo de regulação de serviços públicos competitivos:

a) liberdade de entrada, de forma que todos os que preencham certos requisitos mínimos possam prestar os serviços (mediante autorização administrativa

\footnotetext{
7 A Intelig iniciou suas operações no Brasil em 2000, atuando como empresa autorizada (empresa-espelho), portanto sob o regime jurídico privado, no mercado de chamadas de longa distância inter-regionais e internacional (VENTURA, 2001). No caso de antecipação de metas da Telefônica, a Intelig teve atuação de menor intensidade que a da concessionária (Embratel), por isso não está sendo analisada neste trabalho.
} 
vinculada);

b) livre acesso ao mercado, isto é, à rede, às infra-estruturas: à doutrina das instalações essenciais;

c) liberdade de contratação e de formação dos preços; e

d) liberdade de investimentos, sem compromisso vinculante quanto a investimentos e taxas de retorno.

Esses instrumentos são indispensáveis para que se possa realizar a competição - que é pressuposto da eficiência na prestação dos serviços objeto de tais atividades competitivas (GROTTI in SUNDFELD, 2002:62-63).

Nusdeo (2002, p.160) apresenta como premissa para a implantação da competição em setores regulados a capacidade do sistema de efetivamente funcionar em sistema de competição. Afirma que a privatização "relaciona-se não apenas à transferência da titularidade de concessões, permissões e autorizações para exploração de certos serviços e atividades das pessoas de Direito Público para as de Direito Privado, mas também à criação de um ambiente de mercado e de concorrência nos setores privatizados".

O grande desafio é proporcionar as condições para a livre concorrência mesmo tratando-se de setores regulados. Por isso, confirmada a possibilidade de funcionamento do setor em regime de competição, deve-se ter fases de transição da regulação total e direta para a indireta, mantendo os competidores sujeitos tanto a regimes de regulação quanto a regras de defesa da concorrência (NUSDEO, 2002).

Desse modo, as agências reguladoras têm, além das atribuições de regular e físcalizar os setores, a função de implantar e manter a livre-concorrência. Cabe destacar que as funções de implementação e proteção da concorrência ficam limitadas pelas competências dos órgãos do sistema nacional de defesa da ordem econômica (Conselho Administrativo de Defesa Econômica - CADE, Secretaria de Direito Econômico - SDE e a Secretaria de Acompanhamento Econômico do Ministério da Fazenda - SEAE).

A atuação das agências reguladoras é fundamental para o estabelecimento de ambiente efetivamente competitivo nesses setores, pois elas devem garantir a criação e a manutenção de estruturas de mercado favoráveis à competição a partir da reorganização da forma de exploração dos setores. Essa reestruturação requer algumas medidas básicas, como o desmembramento das atividades complementares de uma mesma cadeia produtiva, estabelecimento de concorrência em fases da prestação do serviço público e a criação de regras que previnam a concentração econômica (NUSDEO, 2002).

Para garantir o desmembramento das atividades econômicas complementares no setor de telecomunicações, a privatização foi feita dividindo-se os serviços em modalidades que são adquiridas pelos usuários de forma separada (telefonia fixa local, telefonia fixa interurbana e 
telefonia móvel, por exemplo). Contudo, nem todas as fases da prestação do serviço de telefonia podem ser feitas em regime de competição. Há algumas atividades que permanecem como monopólio natural $^{8}$, e são relacionadas a estruturas, sistemas e equipamentos que devem ser utilizados por todas as prestadoras. Sem o acesso dos competidores a essa infra-estrutura, não é possível manter a concorrência na prestação do serviço. A fiscalização do acesso dos concorrentes a essa estrutura básica é função da agência reguladora. Um exemplo típico do setor de telecomunicações é a interconexão, ou "ligação entre redes funcionalmente compatíveis, de modo que os usuários de serviços de uma rede possam comunicar-se com os usuários de outras" (NUSDEO, 2002, p.172). É papel da ANATEL editar normas e fiscalizar o cumprimento da obrigatoriedade de conexão entre as redes, sem discriminação e a preços isonômicos, garantindo a operação integrada.

O estabelecimento da concorrência horizontal é fundamental para o modelo de competição dos setores privatizados. É ela que garante o direito dos usuários de escolher a prestadora dos serviços entre diversificadas opções. No setor de telecomunicações, a legislação prevê diferenciação entre os serviços de interesse restrito e os de interesse coletivo.

Os serviços de interesse restrito estão submetidos ao regime de autorização, ou seja, há uma intervenção mínima do Estado na iniciativa dos autorizados. Os serviços de interesse coletivo, por sua vez, estão submetidos a deveres de continuidade e universalização, podendo ser prestados no regime público (concessionárias) ou no regime privado (empresas-espelho). É na atuação concomitante nesses dois regimes dentro de uma mesma modalidade (telefonia fixa, telefonia móvel etc) que se caracteriza a concorrência do setor.

Nusdeo (2002) reforça a importância da atuação da agência reguladora para estimular a entrada de novos concorrentes (entrantes potenciais, no modelo de Porter (1997)) e garantir as condições para a concorrência. Assim é que às concessionárias de telefonia fixa das quatro regiões foram impostos deveres de universalização e continuidade do serviço, até por já atuarem no setor antes da privatização e terem a infra-estrutura necessária, e concorrentes na modalidade de autorização ficaram isentos de tais ônus, pois a eles cabe instalar toda a rede e

\footnotetext{
${ }^{8}$ Pode-se definir monopólio natural como "uma atividade na qual os custos de produção por uma única empresa - em um determinado nível absorvível pelo mercado - são decrescentes à medida que sua produção aumenta, seguindo essa tendência até alcançar toda a produção do mercado. Seus custos em regime de monopólio, assim, são inferiores aos em que incorreriam várias empresas, individualmente, num mercado competitivo, pois os altos custo exigem a produção em grande escala, e o mercado absorve apenas a oferta de uma empresa nesse nível de produção. Assim, seriam as próprias condições estruturais desses setores que impediriam a sua organização em regime de concorrência. A existência de monopólios naturais exige a proteção dos consumidores contra os seus malefícios, sendo a regulação a solução apontada pela doutrina econômica para lidar com essas estruturas de mercado. As formas mais comumente associadas à regulação de monopólios naturais são a nacionalização das empresas atuantes no setor e/ou a criação de órgãos reguladores” (NUSDEO in SUNDFELD, 2002:161).
} 
estrutura necessária à operação do serviço.

Para Turczyn (2002, p.208),

\begin{abstract}
A nova função do Estado seria, em primeiro lugar, a de criar o mercado competitivo, uma vez que não existe, ainda, um mercado concorrencial de serviço público, em razão do regime monopolista anterior. Pelo fato de o serviço de telecomunicações ser um serviço público, o Estado deve, inicialmente, dirigir a construção deste mercado, para que futuramente possa ele funcionar em regime de livre concorrência. Entretanto, é o Estado que possui a titularidade do serviço, podendo influir neste mercado para que ele não traga prejuízo ao direito dos usuários. O Estado atua nestes setores através das [...] agências reguladoras.
\end{abstract}

Visando coibir a concentração econômica ou nova monopolização desses mercados, pela própria iniciativa privada, a ANATEL, dentro de seus limites de atuação, assim como o CADE, no âmbito de suas atribuições enquanto órgão de defesa econômica, deve fiscalizar, regular e proteger a livre concorrência no setor de telecomunicações, impedindo, exemplificativamente, a exploração de uma mesma modalidade de serviço em regimes jurídicos distintos (público e privado) por um mesmo grupo econômico (NUSDEO, 2002).

\title{
2.6 Conselho Administrativo de Defesa Econômica - CADE
}

O Conselho Administrativo de Defesa Econômica (CADE) foi criado pela Lei $n^{o}$ 4.137, de 10 de julho de 1962, tendo sido transformado em autarquia federal, vinculado ao Ministério da Justiça, pela Lei no 8.884, de 11 de junho de 1994. Tem sede no Distrito Federal e tem poderes de fiscalizar e repreender atos de concentração econômica.

É composto internamente por um presidente e seis conselheiros indicados diretamente pelo Presidente da República e com mandatos de dois anos.

Tem como atribuições principais apurar e reprimir abusos do poder econômico, decidir sobre a existência ou inexistência de infração da ordem econômica e decidir sobre a legalidade ou não de atos de concentração do poder econômico, analisando fusões, joint ventures e outras práticas que possam restringir a livre concorrência no mercado. Cabe ao CADE, então, aplicar penalidades quando constatada a existência de prática anticompetitiva (LEHFELD, 2001).

O CADE conta com o apoio da Secretaria de Direito Econômico (SDE), responsável por instaurar e conduzir inquéritos administrativos para apuração de infrações de ordem concorrencial, devendo emitir pareceres sobre os atos de concentração empresarial e remeter tais pareceres ao CADE para julgamento posterior. Conta, também, com a Secretaria de Acompanhamento Econômico do Ministério da Fazenda (SEAE), para emitir pareceres sobre 
os aspectos econômicos das possíveis infrações de ordem concorrencial.

A Lei Geral de Telecomunicações define a atuação da ANATEL com relação a controle, prevenção e repressão de infrações contra a ordem econômica, mas ressalvando as hipóteses decisórias do CADE (a independência decisória da ANATEL não pode interferir na esfera de decisão do $\mathrm{CADE})^{9}$.

Sundfeld (2002, p.21-22) esclarece que a ANATEL não incorpora, no setor de telecomunicações, as competências originárias do CADE, embora cumpra um "papel jurídico relevante quanto à concorrência, seja exercendo papel normativo na definição da estrutura do setor [...], seja atuando como preparador dos processos a serem submetidos ao CADE".

Nusdeo (2002) antecipa a existência de potenciais conflitos de competência entre as agências reguladoras e os órgãos de defesa econômica e defende a importância de atuação conjunta entre eles para aumentar a eficácia e a eficiência na implantação (e na manutenção) da concorrência nos setores privatizados.

\begin{abstract}
De um lado, estão claros a competência e o dever de cada uma das agências reguladoras de implantar a concorrência nos serviços e atividades sob sua fiscalização e regulação, sempre que compatível com a estrutura da atividade e com os demais objetivos fixados nas leis. [...] De outro lado, é também indubitável a competência do CADE para aplicar os conceitos estabelecidos na Lei 8.884, de 1994, e, salvo no caso do setor de telecomunicações, da SDE para investigar práticas anticompetitivas (NUSDEO, 2002, p.179).
\end{abstract}

Importante verificar que deve haver uma aplicação uniforme das políticas e normas de defesa da concorrência em todos os setores da economia, independente de sua classificação como serviços públicos. E que as agências reguladoras são tecnicamente mais capacitadas a apontar alternativas em setores e casos com grande especificidade.

No caso específico do setor de telecomunicações, a Lei 9.472/97 define entre os objetivos da ANATEL o desafio de promover a livre competição nos serviços de telecomunicações e traz, ainda, regras de defesa da concorrência.

A legislação prevê a atuação da ANATEL na investigação preliminar e instauração de

\footnotetext{
9 “Artigo $7^{\circ}$ - As normas gerais de proteção à ordem econômica são aplicáveis ao setor de telecomunicações, quando não conflitarem com o disposto nesta Lei.

$\S 1^{\circ}$ Os atos envolvendo prestadora de serviço de telecomunicações, no regime público ou privado, que visem a qualquer forma de concentração econômica, inclusive mediante fusão ou incorporação de empresas, constituição de sociedade para exercer o controle de empresas ou qualquer forma de agrupamento societário, ficam submetidos aos controles, procedimentos e condicionamentos previstos nas normas gerais de proteção à ordem econômica.

$\S 2^{\circ}$ Os atos de que trata o parágrafo anterior serão submetidos à apreciação do Conselho Administrativo de Defesa Econômica - CADE, por meio do órgão regulador.
} 
processo administrativo para apuração de infrações à ordem econômica no setor de telecomunicações. Na lei 8.884/94, tal atribuição é de competência da SDE. A Lei Geral de Telecomunicações resguardou somente o campo de atuação do CADE, nada informando sobre a atuação da SDE e da SEAE.

\footnotetext{
Nesse sentido, no tocante à investigação e apuração de condutas lesivas à concorrência, é competente a ANATEL, devendo o CADE decidir sobre os processos instaurados e sobre recursos de ofício das decisões da Agência pelo arquivamento de processos administrativos (NUSDEO, 2002, p.181).
}

Como a Lei Geral de Telecomunicações também não especifica a exclusividade de atuação da ANATEL, a doutrina entende serem mantidas as competências da SDE e DA SEAE de forma residual.

A ANATEL pode, ainda, aplicar medidas de prevenção para a cessação de práticas restritivas da concorrência no setor de telecomunicações.

Importante é constatar que a agência reguladora pode identificar a existência da prática anticompetitiva ou de infração à ordem econômica, mas, feito isso, deve ser instaurado o procedimento administrativo definido pela Lei 8.884/94, que se encerrará com uma decisão proferida pelo Conselho Administrativo de Defesa Econômica (CADE).

$\S 3^{\circ}$ Praticará infração de ordem econômica a prestadora de serviço de telecomunicações que, na celebração de contratos de fornecimento de bens e serviços, adotar práticas que possam limitar, falsear ou, de qualquer forma, 


\section{CAPÍTULO III}

\section{Solução de Conflitos no Setor de Telecomunicações}

O conflito é iniciado por uma frustração, por uma necessidade não satisfeita, podendo ocorrer em qualquer tipo de relacionamento humano, seja entre grupos de pessoas, organizações ou pessoas agindo individualmente. Pode ser apenas uma divergência de opiniões ou uma questão de impasse de grande repercussão mundial. O importante é que, quanto maior a dimensão do conflito, mais difícil fica solucioná-lo.

Os conflitos surgem em qualquer ambiente em que haja indivíduos com objetivos diferentes. Dentro do ambiente organizacional, as chances de se ter conflitos aumentam consideravelmente. Isso porque em uma organização encontram-se, juntas num mesmo local de trabalho, pessoas com personalidades, metas pessoais e histórico de vida totalmente diferentes e conflitantes. Essas pessoas vêem-se obrigadas a compartilhar não só o mesmo ambiente, mas os mesmos recursos e objetivos organizacionais. Poderão estar trabalhando num mesmo grupo, defendendo as mesmas idéias, e deverão buscar um ponto comum para evitar os desgastes de discussões dentro da equipe.

Detectado o conflito em uma relação, ele poderá ser encarado pelas partes envolvidas como algo positivo, construtivo, que trará benefícios e alternativas à solução do impasse, ou como algo destrutivo, prejudicial e danoso à negociação.

É comum pensar-se em conflito como algo ruim, disfuncional, indicando que algo está errado, precisando ser reparado, e de que dele hão de decorrer conseqüências destrutivas. Essa visão negativa do conflito tem sua origem em vários aspectos (LEWICKI; LITTERER, 1994):

- processos competitivos, nos quais as partes competem umas contra as outras de forma expressa porque acreditam que seus objetivos são fundamentalmente opostos;

- percepção distorcida, já que em situações de conflito e tensão é muito comum as partes focarem suas próprias necessidades e perspectivas, ampliando a importância da posição (e não mais dos reais interesses); 
- domínio da emoção sobre a razão;

- declínio da comunicação, já que as partes tendem a evitar estabelecer diálogos com aqueles que se opõem a suas posições;

- indefinições sobre as questões centrais, não há mais o foco naquilo que é mais importante para cada parte;

- posições fixas, rígidas e que tendem a se tornar ainda mais fortes com os desafios da outra parte, fazendo com que uma parte se negue a aceitar alternativas levantadas pela outra para evitar a sensação de perda;

- as diferenças são maximizadas e as semelhanças minimizadas conforme aumenta a tensão da situação;

- as partes, então, acabam ficando cada vez mais centradas em suas próprias posições, menos tolerantes e menos abertas a sugestões da outra parte.

A negociação é, aliás, o modo mais usado para solucionar um conflito, seja ele, por exemplo, conflito de opiniões ou de interesses (embora se possa negociar mesmo sem existir conflito).

\section{$\underline{3.1 \text { O Conflito e suas Classificações }}$}

Lewicki e Litterer (1994) classificam os conflitos conforme o nível, a saber:

- conflito intrapessoal ou intrapsíquico, que inclui os conflitos internos, que ocorrem dentro do indivíduo e que se originam a partir de idéias, emoções, sentimentos e valores;

- conflito interpessoal, que ocorre entre pessoas diferentes;

- conflito intragrupal, ou seja, dentro do próprio grupo (entre os membros de um determinado grupo);

- conflito intergrupal, o mais complexo, que ocorre entre grupos, envolvendo grande número de pessoas e de interações.

Sparks (1992, p.98 apud MARTINELLI; ALMEIDA, 1998, p.53) classifica os conflitos com base em sua solubilidade, a saber:

- conflito terminal, ou "ganha-perde", que parece impossível de se solucionar por meio do acordo;

- conflito paradoxal, que tem um grau questionável de solubilidade, aparentemente obscuro para as partes; 
- conflito litigioso, ou "ganha-ganha", é aquele que parece solúvel pelo acordo. O mesmo autor (SPARKS, 1992, p.98 apud MARTINELLI; ALMEIDA, 1998, p.54) classifica os conflitos com base em sua intensidade:

- conflitos muito intensos, que estão presentes quando os interesses envolvidos são altamente relevantes para as partes, fazendo com que elas assumam um papel bem ativo;

- conflitos menos intensos, quando os interesses não são tão cruciais para as partes.

Lebel (1984 apud MARTINELLI; ALMEIDA, 1998, p.60-62), por sua vez, classifica os conflitos a partir de sua natureza, ou seja, propõe três tipos de classificação com base em dimensões distintas: comportamentos, contrários e momentos da ação.

Desse modo, quanto aos comportamentos os conflitos podem ser falhas conflitantes, conflitos de opinião ou conflitos de interesse. Quanto aos contrários, há conflitos individuais, conflitos de igual para igual, hierárquicos, raciais, entre as instituições e organizações da sociedade, neutros ideologicamente, espontâneos e voluntários e conflitos de posse. Quanto aso momentos da ação, os conflitos podem ser sobre os fatos, sobre as causas, sobre os obstáculos, sobre os objetivos, sobre os meios ou sobre os valores.

\section{$\underline{\text { 3.2 Formas de Solução de Conflitos }}$}

Para solucionar problemas e conflitos, as partes podem usar técnicas e estratégias para que elas próprias se acertem, buscando um processo de negociação integrativa e não distributiva (negociação ganha-ganha, privilegiando o relacionamento duradouro e satisfação de todos os envolvidos ao invés de divisão de resultados ou barganha).

Quando as partes, contudo, fixam suas posições, privilegiando-as em detrimento das suas reais necessidades e interesses, a percepção que passam a ter da realidade, da própria negociação e da outra parte, fica distorcida (assim como os seus julgamentos ficam comprometidos), a eficácia da comunicação diminui, passando a ser usada como arma para atacar a outra parte, e não como forma de chegar ao acordo.

As partes também podem, então, optar por chamar uma terceira pessoa, imparcial, não envolvida no processo. Podem fazer isso por não terem outra opção (a situação está insustentável, há grande desconfiança, o conflito entre partes parece maior que a possibilidade do acordo), ou porque querem diminuir custos, chegar a um acordo de forma mais rápida e eficaz, até mesmo para não comprometer negociações futuras. 
Há quatro diferentes formas de envolvimento da terceira parte na solução do conflito:

\begin{tabular}{|c|c|c|c|}
\hline \multirow{4}{*}{$\begin{array}{l}\text { Nível de } \\
\text { controle } \\
\text { da terceira } \\
\text { parte sobre } \\
\text { o processo }\end{array}$} & \multicolumn{3}{|c|}{ Nível de controle da terceira parte sobre o resultado } \\
\hline & & Alto & Baixo \\
\hline & Alto & "Inqusição" & Mediação \\
\hline & Baixo & Arbitragem & Negociação \\
\hline
\end{tabular}

Figura 3 - Formas de envolvimento de uma terceira parte na solução do conflito Fonte: LEWICKI; LITTERER, 1994, p.352

Assim, na negociação as partes mantêm o controle tanto do processo quanto do resultado. No outro extremo, a inquisição retira toda a influência das partes, e o terceiro interventor assume o controle tanto do processo quanto do resultado.

A mediação e a arbitragem são formas intermediárias. A mediação é uma "intervenção pacífica de acerto de conflitos para produzir um acordo, sendo a solução sugerida e não imposta às partes interessadas" (MARTINELLI; ALMEIDA, 1998, p.71). Dessa forma, as partes perdem o controle do processo, mas mantêm o controle sobre o resultado (afinal, tratase de mera sugestão, não tendo força coercitiva que as obrigue a aceitar a solução proposta pelo mediador).

A mediação é baseada em regras e procedimentos preestabelecidos.

A função do mediador é ajudar as partes a negociar de forma efetiva. Não compete a ele impor uma solução. É de fundamental importância o relacionamento entre as partes, e o mediador deve ajudar a fortalecer essa ligação, utilizar as habilidades dos próprios negociadores, fazendo com que as partes cheguem à solução colaborativa, assumindo um compromisso.

A arbitragem é um "processo de julgamento com veredito de um árbitro, a partir das necessidades das partes" (MARTINELLI; ALMEIDA, 1998, p.71). As decisões do árbitro podem ser obrigatórias ou voluntárias, de acordo com as regras previamente estabelecidas pelas partes.

No caso específico do setor de telecomunicações, nota-se a presença de três institutos chamados de arbitragem. Há a arbitragem privada, prevista nos contratos de concessão como forma alternativa de solução de conflitos, exatamente visando evitar longas e desgastantes 
demandas judiciais e garantindo a participação da agência reguladora, detentora de conhecimentos específicos e peculiares do setor.

Há, ainda, a arbitragem conduzida pela ANATEL enquanto agência reguladora, que pode ocorrer de duas formas distintas. O Regulamento Geral de Interconexão (RGI) prevê as regras de um desses modelos de arbitragem, que deve ser adotado no caso de decisões sobre interconexão de redes. O Regimento Interno da ANATEL, por sua vez, apresenta a arbitragem como um procedimento administrativo na qual a decisão é tomada por um corpo colegiado, formado por três membros. Em ambos os casos, a decisão da ANATEL é passível de recurso ao Poder Judiciário.

A negociação, a conciliação, a mediação e a arbitragem são consideradas métodos alternativos de solução de conflitos por serem meios de resolução de disputas ou controvérsias que não envolvem o recurso ao Poder Judiciário, ou seja, sem a intervenção do poder coercitivo estatal, consubstanciado em processos formais. O termo é originado da expressão Alternative Dispute Resolution - ADR, iniciado em pesquisas na Havard University, nos Estados Unidos, e representa uma forma privada de solução de conflitos de diversas naturezas, com segurança jurídica, celeridade, redução de custos, autonomia da vontade das partes e facilitação de relacionamentos duradouros.

O envolvimento de um terceiro no processo de solução do conflito é importante quando as partes percebem que não mais são capazes de chegar ao acordo sem a intervenção de outras pessoas, imparciais e sem interesses diretos no resultado da negociação.

As principais vantagens da introdução de uma terceira parte na solução do conflito são a melhoria no processo de comunicação, priorização dos pontos realmente relevantes, revisão do tempo de negociação, até porque as partes ganham algum tempo para refletir e melhorar seu posicionamento e relacionamento, além da freqüente diminuição de custos.

Hampton (1991 apud MARTINELLI, 2002, p.22-24) define quatro modos para a administração do conflito.

A acomodação é um instrumento para manipulação do conflito, pois adota-se a estratégia de encobrir, esconder o conflito, seja minimizando sua importância ou seriedade, negando sua existência ou simplesmente considerando-o de forma superficial.

Quando se usa o poder de forma extrema, há a dominação, ou seja, uma parte impõe à outra a solução que deseja, permitindo que se alcance a solução de forma rápida, mas que pode causar extrema insatisfação para a parte que nada receber.

No compromisso, cada parte cede um pouco na busca de uma solução que satisfaça, 
ainda que parcialmente, todas as partes.

A solução integrativa de problemas prevê a possibilidade de satisfação total e completa das partes. Não há barganha, cessões mútuas ou tentativas de imposição da vontade de uma parte sobre a outra, mas, sim, a busca por uma solução que atenda totalmente aos interesses das partes envolvidas.

\section{$\underline{\text { 3.3 A Negociação como forma de solução de conflitos }}$}

Há várias definições de negociação, pois cada autor a conceitua de uma forma diferente, dependendo de sua visão do processo e dos objetivos que se pretende alcançar com ela.

Lewicki e Litterer (1994) definem negociação como um processo formal e civilizado que ocorre quando as partes envolvidas em uma situação complexa de conflito tentam encontrar uma solução aceitável para ambas, ou seja, como uma forma viável para solucionar um conflito que possua as seguintes condições:

- presença de duas ou mais partes (que podem ser pessoas, grupos, organizações), já que se considera a negociação como um processo interpessoal ou intergrupal;

- existência de conflito de interesses entre algumas das partes;

- intenção em negociar porque as partes acreditam serem capazes de, por meio da negociação, encontrar uma solução mais interessante do que a que a outra parte ofereceria espontaneamente, há a possibilidade de se ter um acordo melhor após as influências de uma parte sobre a outra no processo de negociação;

- a priori, as partes preferem tentar encontrar a solução sozinhas, chegar ao acordo sem a interferência de outras partes e sem disputas muito severas e declaradas entre elas;

- $\quad$ as partes esperam ceder e receber, conceder e ganhar, simultaneamente.

Acuff (1998, p.28) afirma que "negociação é o processo de comunicação de mão dupla cujo objetivo é chegar a um acordo mútuo sobre necessidades e opiniões divergentes".

Importante se faz ressaltar que o objetivo primordial da negociação deve ser, sempre, a busca do acordo e da satisfação das necessidades de todos os envolvidos.

Qualquer que seja a situação da negociação, alguns aspectos se fazem primordiais: busca do acordo e de relacionamentos duradouros, utilização adequada da comunicação, flexibilidade, ética, planejamento, conflitos etc. Torna-se necessária, então, uma visão geral do processo de negociação, numa tentativa de interligar todos esses aspectos. 
Hodiernamente, com as situações se apresentando cada vez mais complexas, é comum ter-se elementos que interagem todo o tempo nos diversos sistemas que integram o ambiente. E essas interações são marcadas por negociações, concessões e acordos. Assim, entender o todo no qual esteja situada a negociação, de forma sistêmica, facilita a obtenção de resultados satisfatórios para as partes envolvidas, privilegiando o acordo e o relacionamento futuro em detrimento das posições atuais.

Para Schoderbek, Schoderbek, Kefalas (1990, p.13), "sistema é o conjunto de objetos com relações entre os objetos e os atributos relacionados com cada um deles e com o ambiente, de maneira a formar um todo".

Os objetos são os elementos do sistema. Sob o ponto de vista estático, são as partes do sistema e, sob o ponto de vista funcional, são as funções básicas desempenhadas pelas partes do sistema. Existem três tipos de partes: as entradas (inputs) que são a força inicial, dando ao sistema as necessidades operacionais, os processos que transformam as entradas em saídas e as saídas (outputs) que são os resultados das operações do processo (o porquê, a razão principal da existência do sistema).

Os relacionamentos são as fronteiras que ligam os objetos. E os atributos são as propriedades (ou características) tanto dos objetos como dos relacionamentos. Elas manifestam o modo como algo é conhecido, observado ou introduzido no processo.

O ambiente é o que está fora do sistema, seja controlável ou não, e pode determinar o desempenho desse sistema. Destaca-se que o ambiente externo é estabelecido, fixo e nada tem a ver com o sistema em si, mas o ambiente interno tem significativa influência no desempenho do sistema.

O conceito de todo é diferente do conceito da soma das partes porque quando as partes estão agregadas e formando o todo, tem-se uma estrutura independente com papel distinto do papel das partes individualmente.

A figura a seguir ilustra o ambiente de um sistema, facilitando a interpretação desses conceitos: 


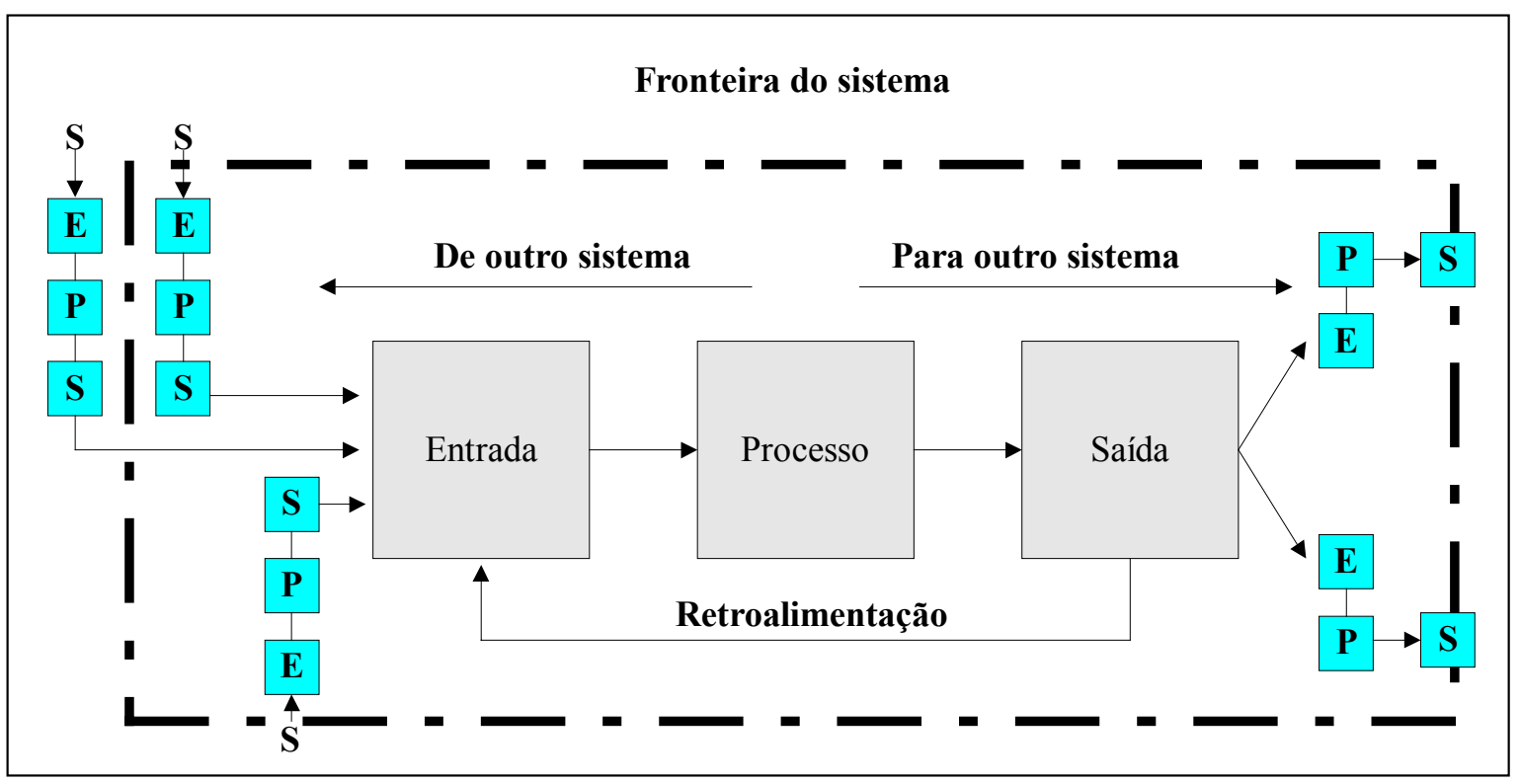

Figura 4: Diagrama de Sistemas

Fonte: SCHODERBEK, SCHODERBEK, KEFALAS, 1990, p.25

O conceito de que o todo é maior que a soma das partes originou-se na Teoria Geral dos Sistemas (TGS), que foi formulada por uma equipe multidisciplinar de cientistas cujo principal motivador foi Ludwig von Bertalanffy (1968 apud MARTINELLI, 2002, p.115116), ainda nos anos 30. Baseado no conceito de Aristóteles ("O todo é maior do que a soma das partes"), afirmava que todo indivíduo é direcionado à consecução de metas e para entender o comportamento de um organismo, faz-se necessário vê-lo como um todo, com sua tendência aos objetivos, com sua organização de partes interligadas e em interação.

Mais que uma metodologia, a TGS é um esqueleto, um modelo de análise do mundo empírico, um modelo de como analisar fenômenos complexos enquanto sistemas, um todo com partes inter-relacionadas. A TGS enfatiza ser impossível a solução de problemas através de análises isoladas e a abordagem sistêmica analisa a complexidade enfatizando o todo, em que um ou vários ambientes estão interagindo com o sistema.

A negociação será mais efetiva, isto é, visará ganhos mútuos, abrindo espaço para futuras negociações, se for possível analisá-la de forma sistêmica (a partir do todo no qual ela está inserida).

A negociação deve sempre ter como objetivo a satisfação de todos os lados envolvidos, ambos ganhando ao invés de um lado perder para o outro ganhar.

Contudo, além das negociações ganha-ganha, tem-se também negociações do tipo ganha-perde e mesmo perde-perde. 


\subsubsection{As Variáveis Básicas da Negociação}

As três variáveis básicas da negociação são: poder, tempo e informação. Para se conseguir uma negociação efetiva, com resultados positivos, é necessário que pelo menos uma dessas três variáveis esteja presente de forma intensa. O ideal é que as três existam, estejam conectadas e sejam corretamente utilizadas na negociação.

O poder pode ser pessoal ou circunstancial. O poder pessoal é inato, e está presente em todas as situações em que o indivíduo está presente, independentemente de papéis, conhecimentos e habilidades. Há poder da moralidade, da atitude, da persistência e da capacidade persuasiva. O poder circunstancial depende da situação, do momento, é influenciado pelo ambiente. Há o poder do especialista, de investimento, da posição, da legitimidade, da concorrência, do precedente, dos riscos, do compromisso, de conhecer as necessidades, de recompensa e de punição, de identificação e, por fim, de barganha.

O tempo inclui noções de presente, passado e futuro, devendo ser definido pelas próprias partes, como uma forma de reforçar o respeito às necessidades da outra parte e a fim de favorecer relacionamentos futuros.

A terceira variável é a informação. É muito importante utilizar todas as informações conseguidas pela parte na negociação, até mesmo porque, conhecendo as reais necessidades da outra parte, é possível encaminhar o processo para um resultado ganha-ganha de forma mais rápida e eficiente. A informação pode ser conseguida através da comunicação, quando a parte sabe ouvir o que está sendo dito por seu oponente ou por seus parceiros.

Por isso, é também relevante estabelecer um bom processo de comunicação, evitando ruídos e barreiras, estando atento ao que a outra parte diz, e ser claro ao transmitir alguma mensagem. Além do mais, não se pode esquecer que a comunicação verbal não é a única que existe. Assim, um bom processo de negociação envolve um modo adequado de se estabelecer a comunicação, no momento correto, saber ouvir e conversar, expor suas idéias clara e objetivamente. A comunicação deve, ainda, ser bilateral, com as duas partes manifestando suas vontades para que se possa satisfazer a ambas. 


\section{$\underline{3.4 \text { Conflitos no Setor de Telecomunicacões no Brasil }}$}

Com a privatização, o setor de telecomunicações passou a englobar relações mais complexas, com o envolvimento de agentes antes estranhos ao setor, inclusive com a introdução de uma agência reguladora, o início da concorrência e a mudança no perfil e no comportamento dos usuários.

A agência reguladora tem o papel de mediar os conflitos entre tais agentes, mas nem sempre o acordo é possível. Os contratos de concessão prevêem também a utilização do instituto da arbitragem.

Para solucionar os conflitos, as partes dispõem ainda da negociação, muitas vezes preferida pela redução nos custos e no tempo despendido, além dos benefícios do fortalecimento da relação entre as partes. Outra possibilidade é o recurso ao Poder Judiciário, alternativa considerada prejudicial à imagem da agência reguladora enquanto órgão regulador e decisor.

Alguns conflitos mais recentes do setor de telecomunicações merecem destaque.

O primeiro caso é o da cobrança conjunta de contas telefônicas. O aumento do número de concorrentes no setor possibilitou ao usuário escolher a operadora em cada chamada realizada. Contudo, o usuário recebia a cada mês diferentes contas telefônicas, gerando transtornos e causando insatisfação. Para evitar o problema, foi acertada a emissão de contas conjuntas, ou seja, uma empresa emite a conta, incluindo nela as informações das outras empresas, e recebe uma remuneração por esse serviço.

Inicialmente as empresas estipularam um preço considerado elevado pelas concorrentes para a emissão das contas conjuntas, sendo necessária a intervenção da agência reguladora. A ANATEL propôs redução imediata do valor até definição dos custos reais. Para isso, ela precisaria de informações (assimétricas). As empresas, então, contrataram uma empresa de consultoria e auditoria para verificação do preço adequado. Findo esse processo, a ANATEL proferiu despacho fixando o valor a ser cobrado pela emissão da conta conjunta.

No caso das redes de interconexão, apesar da previsão contratual e legal da obrigatoriedade de conexão (o que, de fato, já ocorre na prática, até porque operacionalmente a junção de muitas redes foi feita ainda na existência do Sistema Telebrás), não há um acordo formal celebrado e homologado pela agência reguladora. As questões operacionais foram resolvidas por despacho da ANATEL. As questões comerciais estão sendo discutidas e apresentadas à agência pelas operadoras para, então, a ANATEL, por decisão administrativa, 
homologar o acordo de interconexão.

Um outro caso bastante complexo é o da antecipação de metas e liberação de concessionárias para atuação em outros setores e a prestação de outros serviços. O primeiro caso ocorrido no Brasil, marcando a passagem da fase de competição limitada, caracterizada pelo duopólio, para a fase de competição total, foi o da antecipação de metas da Telefônica (concessionária da Região III).

A primeira concessionária a conseguir a certificação de cumprimento de metas foi a Telefônica. É exatamente esse o foco do presente trabalho: a partir da análise do conflito entre Embratel e Telefônica, em função da antecipação de metas da Telefônica, compreender as formas de solução de conflitos preferidas pelas empresas prestadoras de serviços de telecomunicações e o grau de satisfação com as formas adotadas. 


\section{CAPÍTULO IV}

\section{PROCEDIMENTOS METODOLÓGICOS}

Para o desenvolvimento do presente estudo é utilizado o método qualitativo. Para Richardson (1999, p. 79),

o método qualitativo difere, em princípio, do quantitativo, à medida que não emprega um instrumental estatístico como base do processo de análise de um problema. Não pretende numerar ou medir unidades ou categorias homogêneas.

O presente trabalho pode ainda ser classificado como um estudo descritivo. Segundo Vieira (2002), a partir da pesquisa descritiva é possível expor as características de um certo fenômeno em estudo, mas sem a intenção ou a responsabilidade de explicá-lo.

É utilizado o procedimento do estudo de caso, indicado para pesquisas de campo, e cujo objetivo primordial é investigar um fenômeno ou situação específica, analisando seu contexto e processos ou etapas envolvidas.

Inicialmente, são abordados conceitos teóricos relevantes para a compreensão da questão da privatização das telecomunicações no Brasil. É apresentada revisão bibliográfica, com a opinião de diversos autores, encontrados em variadas fontes de informação, como livros, artigos, trabalhos e teses, revistas, jornais e na Internet.

Finda a revisão bibliográfica, há a análise dos conflitos entre a Embratel e a Telefônica no período pós-privatização das telecomunicações, buscando identificar as formas encontradas para sua solução e as conseqüências para os envolvidos. São analisadas as informações coletadas a partir da divulgação em revistas e jornais especializados em negócios e/ou telecomunicações para embasamento conceitual e estruturação do roteiro de entrevista.

Identificados alguns aspectos do caso em estudo nas fontes secundárias, são apresentadas as entrevistas na agência reguladora ${ }^{10}$, no $\mathrm{CADE}^{11}$ e com uma das empresas

\footnotetext{
${ }^{10} \mathrm{Na}$ ANATEL foram realizadas entrevistas com o Superintendente de Serviços Públicos, Marcos Bafutto, o Assessor Benedito M. D. Barbosa e com o Conselheiro José Leite Pereira Filho.

${ }^{11}$ Para a entrevista no Conselho Administrativo de Defesa Econômica (CADE) foi contatado o presidente, Sr João Grandino Rodas. Por indicação do Sr. Rodas, os comentários sobre a participação do CADE no setor de telecomunicações seriam feitos pelo Dr. Marcelo Amorelli, advogado que trabalhava no CADE e atualmente trabalha na ANATEL. Contudo, não foi possível realizar a entrevista, tendo sido feitos apenas contatos telefônicos.
} 
envolvidas diretamente no conflito (Telefônica ${ }^{12}$ ), visando detalhar a situação de conflito propriamente dita, as estratégias e o posicionamento de cada um, o(s) processo(s) de negociação ocorrido(s), a opção pela forma de resolução do impasse e as possíveis (ou atuais) conseqüências das medidas adotadas no processo (impacto no relacionamento, satisfação dos lados envolvidos, conseqüências para o usuário, entre outros aspectos).

Para a análise das entrevistas realizadas são utilizados os conceitos da fenomenologia, buscando isolar o essencial do fenômeno ora estudado, considerando todas as variações possíveis para chegar-se à essência do fato (conflito) (DARTIGUES, 1992, p.29-33).

Michelini (2001, p.33) explica que a fenomenologia

privilegia a análise das experiências vividas por pessoas, dos fatos e ações e dos registros, centralizando-se na experiência consciente dos sujeitos, focalizando e aprendendo o sentido do objeto (fenômeno) em estudo. Ou seja, a fenomenologia pode ser entendida como uma modalidade de pesquisa qualitativa, que permite a análise de um fenômeno único, a partir de experiências e relatos de pessoas nele envolvidas, direta ou indiretamente.

A fenomenologia tem como função principal a investigação direta e a descrição de fenômenos vivenciados de forma consciente, independente da relação causal e sem a interferência de preconceitos. $\mathrm{O}$ fenômeno chamado realidade não pode mais ser explicado pela relação causa-efeito porque ela é decorrente de intencionalidade. A fenomenologia, então, não questiona o fato em si, mas aquilo que é vivenciado pelos sujeitos ativos do fenômeno em estudo (BICUDO; ESPÓSITO, 1994).

$\mathrm{Na}$ análise fenomenológica é formado um campo de percepção que contém o fenômeno estudado e sujeitos que, por compartilharem experiências, podem compartilhar interpretações. "É importante que seja destacado que o que é visto não é percebido de forma isolada, mas sim em uma série de fenômenos co-percebidos" (BICUDO; ESPÓSITO, 1994, p.19).

Para Forghieri (1993) a fenomenologia surgiu como um método que viabiliza, por meio da redução fenomenológica, o alcance da essência do conhecimento (volta-se à experiência vivida para alcançar a essência por meio da reflexão).

A redução fenomenológica tem dois momentos: o envolvimento existencial, que

\footnotetext{
12 Apesar de inúmeras tentativas de contato e agendamento, a Embratel informou, por meio de sua Diretoria de Publicidade, Imprensa e Relações Públicas, em 04 de novembro de 2003, que realmente não seria possível a realização da entrevista. Desse modo, os dados apresentados são coletados em fontes secundárias. Na Telefônica a entrevista foi realizada com o Sr. Eduardo Navarro de Carvalho, Vice-Presidente de Estratégia Corporativa e Regulatória.
} 
consiste no fato do pesquisador precisar isolar as vivências que ele mesmo teve sobre o fenômeno estudado, buscando abrir-se totalmente às novas informações e vivenciando-as, e o distanciamento reflexivo, quando o pesquisador fica afastado da experiência (embora mantendo-se a ela ligado) para buscar a compreensão do fenômeno (FORGHIERI, 1993).

O fenômeno em estudo é o conflito entre Embratel e Telefônica, ocorrido quando da certificação pela ANATEL do cumprimento antecipado de metas da Telefônica. Para analisar esse caso, são coletadas informações nas fontes secundárias e obtidos relatos (entrevistas) com alguns dos sujeitos envolvidos (representantes das instituições).

\subsection{Perguntas e Modelo de Pesquisa}

Para a realização do presente trabalho são formuladas perguntas de pesquisa associadas à questão central e aos objetivos gerais e específicos definidos para o estudo.

1. Quais as características do período pós-privatização das telecomunicações?

2. Quais as etapas do período pós-privatização das telecomunicações?

3. Qual o papel do CADE na regulação da concorrência e na solução dos conflitos entre as empresas de telecomunicações no ambiente de competição total?

4. Qual o papel da ANATEL na regulação da concorrência e na solução de conflitos entre as empresas de telecomunicações no ambiente de competição total?

5. Qual a contribuição da negociação para o sucesso do modelo de privatização das telecomunicações?

6. Qual a influência das variáveis básicas da negociação na questão das telecomunicações?

7. Qual o papel da ANATEL no conflito entre Embratel e Telefônica?

8. Qual o papel do CADE no conflito entre Embratel e Telefônica?

9. As empresas privilegiam a adoção da negociação como forma de solução de conflitos?

10. As empresas do setor de telecomunicações procuram a jurisdição estatal para solucionar seus conflitos?

11. Como as partes (Embratel e Telefônica) procuraram solucionar o conflito?

12. Qual a forma adotada para solucionar o conflito?

13. Qual foi o grau de satisfação da Embratel e da Telefônica com a solução do conflito?

Richardson (1999, p. 129) afirma que é possível classificar as variáveis segundo a 
relação temporal existente entre elas. Assim, as variáveis independentes são aquelas "que afetam outras variáveis, mas não precisam estar relacionadas entre elas".

As variáveis dependentes "são aquelas afetadas ou explicadas pelas variáveis independentes. Isto é, variarão de acordo com as mudanças nas variáveis independentes" (RICHARDSON, 1999, p.129).

As variáveis intervenientes "são as que, no tempo, estão entre as variáveis independentes e as dependentes" (RICHARDSON, 1999, p.131).

Para este estudo, são definidas as seguintes variáveis:

Variáveis Independentes:

- Modelo de privatização das telecomunicações

- Estrutura da Embratel

- Estrutura da Telefônica

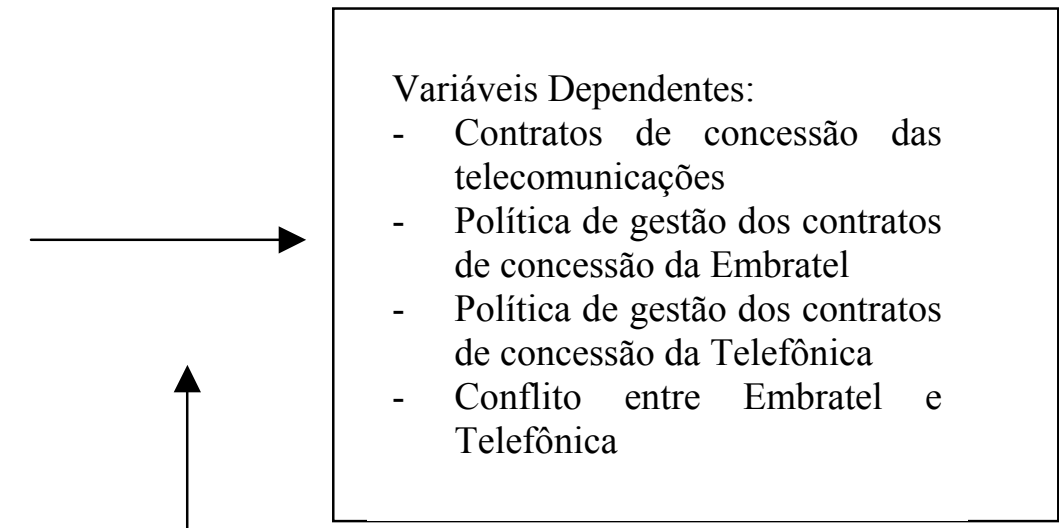

Variáveis Intervenientes:

- Utilização das variáveis básicas da negociação (poder, tempo e informação) pelas empresas Embratel e Telefônica

- ANATEL

- CADE

O trabalho tem como universo de estudo a situação de conflito estabelecida entre EMBRATEL e Telefônica no período pós-privatização das telecomunicações, em especial após a liberalização da Telefônica para a prestação de serviços de telefonia fixa interurbana e internacional em 2002, considerando o papel da ANATEL e do CADE nesse processo.

\subsection{Coleta de Dados: Método e Instrumento}


A coleta de dados ocorre em dois momentos no presente trabalho. Inicialmente são identificados alguns aspectos do caso em estudo (Embratel e Telefônica) nas fontes secundárias (informações divulgadas em revistas e jornais especializados em negócios e/ou telecomunicações para embasamento conceitual e estruturação do roteiro de entrevista).

Concomitantemente são feitas entrevistas na agência reguladora e em uma das empresas envolvidas diretamente no conflito (Telefônica), visando detalhar a situação em estudo.

No que diz respeito a procedimentos metodológicos, as pesquisas qualitativas de campo exploram particularmente as técnicas de observação e entrevistas devido à propriedade com que esses instrumentos penetram na complexidade de um problema (RICHARDSON, 1999, p.82).

Na pesquisa social, é muitas vezes difícil, ou até impossível, coletar dados sobre as pessoas através da observação. Em tais situações, utilizam-se geralmente entrevistas e questionários para obter essas informações (SELLTIZ, 1987, p.15).

Numa entrevista, uma vez que o entrevistador e o entrevistado estão ambos presentes, à medida que as questões são formuladas e respondidas, há oportunidade para um cuidado maior na comunicação das questões e em fornecer informação (SELLTIZ, 1987, p.16-17).

É utilizada pesquisa do tipo semi-estruturada.

A entrevista guiada é utilizada particularmente para descobrir que aspectos de determinada experiência produzem mudanças nas pessoas expostas a ela. $\mathrm{O}$ pesquisador conhece previamente os aspectos que deseja pesquisar e, com base neles, formula alguns pontos a tratar na entrevista. As perguntas dependem do entrevistador, e o entrevistado tem a liberdade de expressar-se como ele quiser, guiado pelo entrevistador (RICHARDSON, 1999, p.212).

Os roteiros para realização das entrevistas estão em anexo. 


\section{CAPÍTULO V}

\section{Análise do Conflito Embratel x Telefônica na Antecipação de Metas}

O conflito entre Embratel e Telefônica, objeto de análise deste estudo, teve início em 2002, quando a ANATEL certificou o cumprimento antecipado das metas de qualidade e universalização da Telefônica, liberando-a, conseqüentemente, para a prestação de serviços telefônicos de longa distância (interurbano) e ligações internacionais.

O modelo de privatização do setor de telecomunicações no Brasil previu a universalização de serviços e a competição. Para alcançar a universalização, foram definidas metas para as empresas concessionárias (portanto, aquelas que têm a prestação do serviço definida para ocorrer em regime público) de expansão de atendimento e de qualidade no Plano Geral de Metas de Qualidade, no Plano Geral de Metas de Universalização, no Plano Geral de Outorgas e nos próprios contratos de concessão.

Para viabilizar a competição no setor de telecomunicações, o modelo previu a separação dos serviços de telefonia fixa e móvel, a divisão do país em regiões geográficas de atuação e, dentro das regiões, em setores, contemplando as cidades que compõem cada região, e o regime de duopólio em cada região, com uma empresa prestando o serviço em regime de concessão, portanto com os deveres de continuidade do serviço e universalização, e uma empresa chamada espelho, em regime de autorização, sem os encargos do regime público. $\mathrm{O}$ modelo previa, ainda, regras sobre o número de concorrentes, quais serviços cada operadora poderia prestar, e em quais regiões ela poderia atuar, e contemplava dois estágios: o de transição, previsto para durar até 2002, com competição limitada e restrita ao serviço de telefonia interurbana, e o de competição total, previsto para iniciar após 2003, quando a concorrência seria mais acirrada pela liberação das concessionárias para atuação em outros serviços e setores com a outorga de licenças a novas operadoras (WOHLERS; OLIVA, 2000).

Com a previsão de liberação já em 2002 para aquelas concessionárias que cumprissem as metas de qualidade e universalização definidas pela agência reguladora, houve a antecipação do estágio de competição total. Teve início, também, a ação agressiva da Telefônica para cumprir as metas até o final de 2001 e poder, assim, iniciar 2002 já com a liberação para prestação dos serviços telefônicos de longa distância (interurbano) e ligações internacionais, acirrando a competição nessa região (que já contemplava uma empresa- 
espelho, a Intelig, em atividade).

É nesse cenário que se instala o conflito entre Embratel e Telefônica.

\section{$\underline{5.1 \text { Embratel }}$}

A Embratel foi criada em 1965 para prestar serviços de telefonia fixa de longa distância nacional (interurbano) e internacional.

No leilão de privatização do Sistema Telebrás, a Embratel foi comprada pela MCI WorldCom. Foi criada, então, a Embratel Participações S/A, uma holding que reunia a WorldCom e outros acionistas minoritários.

Confiando na boa reputação adquirida enquanto estatal, os dirigentes da operadora resolveram não alterar sua denominação comercial, fartamente divulgada em fortes campanhas de marketing por todo o país (WOHLERS, OLIVA, 2000, p. 78).

Já em 2000, quando a ANATEL concedeu autorização sob regime privado para a atuação da Intelig $^{13}$ como empresa-espelho na região IV (serviços de telefonia de longa distância inter-regionais e internacionais), a Embratel passou a sofrer forte pressão da concorrência.

Com a intensificação da concorrência, a Embratel adotou estratégias de investimento em programas de fidelidade e de resposta rápida às políticas de preços promocionais dos concorrentes (WOHLERS; OLIVA, 2000).

Concessionárias como a Telefônica e a Telemar, que conseguiram antecipar o cumprimento de suas metas de qualidade e universalização para 2002, adquiriram o direito de concorrer nos serviços e setores da Embratel, causando conflitos diversos, inclusive aquele objeto de estudo deste trabalho.

E essa concorrência tende somente a crescer, após 2003, com a liberação das demais concessionárias para a prestação de outros serviços telefônicos.

\section{$\underline{5.2}$ Telefônica}

\footnotetext{
${ }^{13}$ A Intelig, empresa-espelho da Região IV, iniciou suas operações em 23 de janeiro de 2000 "adotando uma agressiva estratégia de marketing. O nome Intelig foi escolhido pelo público após intensa campanha publicitária, em 1999, em substituição à denominação anterior - Bonari, consórcio formado pela empresa inglesa de energia
} 
A Telefônica (ou a holding Telecomunicações de São Paulo S/A - TELESP) é a concessionária dos serviços de telefonia fixa no estado de São Paulo (Região III), setores 31, 32 e 34.

Com a privatização, a Telefônica ${ }^{14}$ assumiu a operação da TELESP e CTBC, iniciando um processo de expansão e ampliação do sistema de telefonia fixa do Estado de São Paulo, inclusive na região de Ribeirão Preto, com a compra da CETERP, em dezembro de 1999.

Em julho de 1998, época da privatização, a TELESP tinha cinco milhões e seiscentos mil terminais instalados em todo o Estado e respondia pelos serviços de telecomunicações de voz, texto, dados e imagens em seiscentos e vinte e cinco municípios.

Ventura (2001, p.89) explica que a Telefônica adquiriu estrategicamente a região de maior concentração econômica do país, que inclui São Paulo, que era, nos dizeres de Wohlers e Oliva (2000, p.75), a “jóia da coroa".

Com a privatização, a Telefônica investiu em infra-estrutura e tecnologia, instalando três milhões de linhas em pouco mais de um ano e meio de atividade e foi a primeira operadora a receber da ANATEL o certificado de cumprimento antecipado de metas de universalização do serviço telefônico. É exatamente essa certificação que desencadeia o conflito analisado neste trabalho.

O prazo definido pela ANATEL para cumprimento das metas de qualidade e de universalização, previstas no Plano Geral de Metas de Qualidade (PGMQ) e no Plano Geral de Metas de Universalização (PGMU), foi 31 de dezembro de 2003, porém o Decreto 2592/98 e o Anexo 2 do contrato de concessão aprovado pela Resolução $n^{\circ}$ 26/98 previam a possibilidade de cumprimento antecipado das obrigações de universalização por parte da concessionária do serviço telefônico fixo comutado (STFC).

O processo de liberação da Telefônica para a prestação de serviços de telefonia de longa distância (interurbano) e de ligações internacionais, em função da antecipação do cumprimento das metas de universalização definidas pela ANATEL, iniciou-se com a chamada "Operação Verônica" ${ }^{15 "}$.

elétrica National Grid (50\%), pela France Telecom (25\%) e pela norte-americana Sprint (25\%)" (WOHLERS; OLIVA, 2000, p.80)

${ }^{14}$ Telefônica é empresa do Grupo Telefónica. O grupo possui capital privado, com mais de um milhão e meio de acionistas diretos, oferecendo serviços em quarenta e nove países, sendo Espanha e América Latina seus mercados mais importantes.

${ }^{15}$ Antes da subdivisão da Telefônica em várias linhas de atividade, cabia à Telefónica Internacional a direção de todas as atividades do Grupo na América Latina. A Operação Verônica consistiu na transferência das participações da Telefónica Internacional para as novas linhas de atividade e a mudança de seu nome para Telefónica Latinoamérica. Dessa depende a administração das atividades de telefonia fixa em todos os países latino-americanos em que a Telefônica está presente, embora os ativos da Guatemala e de El Salvador façam 
Em 22 de outubro de 2001, a Telefônica apresentou o documento de "Declaração de Antecipação de Metas do Plano Geral de Metas de Universalização”, afirmando ter cumprido e antecipado as dezoito metas de universalização inscritas no Plano Geral de Metas de Universalização.

A ANATEL contratou quatro empresas de consultoria independentes com o objetivo de verificar se os compromissos assumidos nos contratos assinados com o governo estavam sendo realmente cumpridos. No caso da Telefônica, a empresa contratada foi a Deloitte Touche Tohmatsu, que apresentou um relatório de auditoria independente, concluindo expressamente que a empresa antecipou as metas fixadas para 31 de dezembro de 2003.

Em 29 de outubro de 2001, a ANATEL publicou no Diário Oficial da União a Consulta Pública n 326 sobre a declaração de cumprimento das metas feitas pela Telefônica. Qualquer pessoa poderia encaminhar críticas, sugestões e denúncias às informações constantes no documento até às 24 horas do dia 05 de dezembro de 2001 , através do site da agência, ou até às 17 horas do dia 28 de novembro de 2001 pelo call center.

Durante o período de Consulta Pública, os fiscais da ANATEL intensificaram o trabalho para certificar a antecipação, verificando as denúncias.

Em 05 de Dezembro de 2001 foi encerrada a Consulta Pública com quase duzentas participações.

Em 22 de fevereiro de 2002, a Superintendência de Universalização (SUN) emitiu o informe no $26-U N A C / S U N$, informando que:

a) a declaração de antecipação de metas do PGMU feita pela TELESP obedeceu a todas as imposições inscritas na Resolução nº 280/01, da Agência;

parte da Telefónica Móviles.

No processo de privatização da Telebrás, um consórcio liderado pela Telefónica Internacional adquiriu 51,79\% das ações com direito a voto da TELESP Participações (TP). Essa era a empresa holding que controlava as operadoras de telefonia fixa TELESP S/A e CTBC até o momento da reestruturação societária ocorrida no final de 1999.

As duas operadoras vinham prestando serviços de telefonia básica local, longa distância intrarregional, telefonia pública, além das listas telefônicas e transmissão de dados no estado de São Paulo. Em seguida, no decorrer do ano de 2000, após o lançamento da Operação Verônica por parte do grupo Telefónica, a porcentagem de participação na TELESP aumentou significativamente, subindo de 19,3\% em dezembro de 1999 para 86,6\% no momento.

Em dezembro de 1999, a TELESP comprou 72,6\% da empresa CETERP - Centrais Telefônicas de Ribeirão Preto - e sua subsidiária CETERP Celular. Após uma nova operação em outubro de 2000, a TELESP passou a deter $96,97 \%$ das ações preferenciais e $99,85 \%$ das ações com direito a voto da CETERP. Em novembro de 2000, a CETERP vendeu a CETERP Celular para a TELESP Celular, cujo principal acionista é a Portugal Telecom.

Em novembro de 2000, a CETERP foi incorporada à TELESP. A operação da CETERP já se enquadrava no objetivo de garantir o cumprimento antecipado das metas de qualidade e expansão do serviço exigidas pela ANATEL para permitir à TELESP oferecer outros serviços e entrar antecipadamente no mercado das outras regiões do Brasil. 
b) o sistema de informação montado pela TELESP para o acompanhamento e controle do alcance das metas do PGMU é confiável e foi validado por meio de exame e análise da efetividade dos métodos e procedimentos;

c) todas as denúncias e indícios de não atendimento das metas de universalização foram averiguadas pela SRF;

d) todas a inconformidades encontradas pela fiscalização durante os testes amostrais, bem como as denúncias vindas da Consulta Pública foram sanadas pela TELESP;

e) para cada um dos dezoito itens testados foi encontrada uma amostra ("amostra falha zero") atendendo integralmente ao determinado no PGMU;

f) para o nível de certeza e grau de precisão adotados para o teste amostral, pode-se inferir que há conformidade dos dezoito itens testados com as metas previstas no PGMU para 2003.

No Ato $n^{\circ}$ 23395, de 01 de março de 2002, o Conselho Diretor da ANATEL certifica que foram atendidas pela TELESP as condições relativas ao cumprimento antecipado de obrigações de universalização fixadas para 31 de dezembro de 2003 no PGMU.

\section{$\underline{5.3 \text { O Conflito Embratel } x \text { Telefônica }}$}

Com a certificação de cumprimento antecipado de metas, a Telefônica obteve da ANATEL a liberação para atuação na prestação de serviços de longa distância nacional (interurbano) e internacional. Com a decisão da ANATEL, surgem conflitos.

A Embratel e a Intelig (concessionária e empresa-espelho, respectivamente, dos serviços de telefonia fixa comutada nas modalidades de longa distância nacional e internacional) recorrem à ANATEL e ao CADE, tentando impedir a certificação de antecipação das metas da Telefônica alegando conduta anticompetitiva da empresa ao cobrar pelo uso de sua estrutura de redes para a interconexão uma remuneração superior a dos seus custos quando oferecem o mesmo serviço. Desse modo, ao prestar também o serviço de chamada de longa distância nacional, a Telefônica teria vantagem competitiva nos preços sobre os demais concorrentes (Gazeta Mercantil, 23 de maio de 2002, página A10).

Tanto a ANATEL quanto o CADE não aceitam a posição da Embratel e da Intelig. A Embratel recorre à Justiça Comum e consegue uma liminar, confirmada pelo Tribunal Regional Federal (TRF), impedindo a expansão da atuação da Telefônica para o serviço de chamadas de longa distância nacional (a Telefônica pôde iniciar normalmente a prestação de serviços para as chamadas internacionais). A liminar foi concedida no dia 29 de abril de 2002 , aproximadamente no mesmo momento em que a Telefônica assinava, na ANATEL, as liberações para prestação dos novos serviços (Gazeta Mercantil, 21 de maio de 2002, página C6). A base do recurso da Embratel estava em afirmar que, por se tratar de uma nova 
concessão, a licença para que a Telefônica atuasse nos serviços de longa distância nacional somente poderia ter sido dada após processo de licitação.

A ANATEL recorreu da decisão do TRF em junho de 2002. Concomitantemente, a agência reguladora iniciou estudos sobre a viabilidade de conceder uma autorização temporária para preservar o direito da Telefônica a ampliar a prestação de serviços, o que havia sido conseguido pela antecipação de metas de universalização (Gazeta Mercantil, 24 de junho de 2002, página A10).

No dia 01 de julho de 2002 a ANATEL emitiu a autorização que possibilitou à Telefônica a realização de ligações nacionais originadas no Estado de São Paulo. Em tese, por ter recebido uma autorização, a Telefônica teria o direito de atuar no regime privado, com possibilidade de praticar preços livremente e sem os encargos de concessionária, mas a ANATEL impôs à operadora a assinatura de um termo de compromisso de atuação como se concessionária fosse. Em 03 de julho a Telefônica iniciou a prestação do serviço de ligações inter-regionais, embora ainda limitada aos casos em que os usuários que originassem a chamada estivessem no Estado de São Paulo (Gazeta Mercantil, 02 e 03 de julho de 2002, página $\mathrm{C} 7)$.

Em 08 de julho de 2002 a Embratel conseguiu nova liminar na Justiça Federal de São Paulo, desta vez com o fundamento no artigo 68 da Lei Geral de Telecomunicações ${ }^{16}$, que prevê a impossibilidade de uma mesma operadora ter uma autorização e uma concessão para uma mesma modalidade de serviço. A decisão da magistrada também foi fundamentada no direito da Embratel de ter reserva de mercado no serviço de DDD e de ter garantido o equilíbrio econômico-financeiro do contrato de concessão (Gazeta Mercantil, 08 de julho de 2002, página A8).

Em 29 de julho de 2002 a Telefônica conseguiu derrubar a liminar da Embratel com decisão do Tribunal Regional Federal da $3^{\text {a }}$ Região.

Somente no dia 10 de dezembro de 2002, com a decisão do Superior Tribunal de Justiça, que negou novo pedido de liminar da Embratel contra a atuação da Telefônica nos serviços de longa distância nos demais estados (além de São Paulo) é que a operadora teve a confirmação de seu direito de prestação de serviços de longa distância em todo o território brasileiro, conforme havia sido certificado pela ANATEL em abril de 2002 (Gazeta Mercantil, 11 de dezembro de 2002, página A10).

\footnotetext{
16 “Artigo 68 - É vedada, a uma mesma pessoa jurídica, a exploração, de forma direta ou indireta, de uma mesma modalidade de serviço nos regimes público e privado, salvo em regiões, localidades ou áreas distintas" (Lei n ${ }^{\circ}$ 9.472, de 16 de julho de 1997).
} 
Apesar da certificação da ANATEL ter sido concedida em março de 2002, a Telefônica só conseguiu iniciar os serviços de longa distância nacional em julho de 2002 (e, mesmo assim, restrita a chamadas originadas no estado de São Paulo) em função da "guerra das liminares", como foi chamado pela imprensa o fato de a Embratel persistir tentando cassar, na Justiça Comum, por meio de liminares, a atuação da Telefônica nesse serviço.

Após tantas disputas na Justiça Comum, a ANATEL afirmou entender tal procedimento como grave ameaça ao modelo regulatório adotado na privatização das telecomunicações, pois há a previsão na legislação e nos contratos de concessão de que cabe à agência reguladora dirimir os conflitos decorrentes inclusive das relações entre as concessionárias, além da previsão de recurso à arbitragem ${ }^{17}$. Outro fator importante: a ANATEL conhece as especificidades do modelo, dos contratos de concessão e do setor de telecomunicações como um todo de forma mais ampla que a Justiça Comum, como no caso da decisão proferida que garantia à Embratel o direito de reserva de mercado, condição explicitamente coibida no contrato de concessão (cláusula 26.5, parágrafo único ${ }^{18}$ ) o que garante maior estabilidade ao modelo adotado (Gazeta Mercantil, 05 de julho, página C7, 15 de julho, página C8 e 31 de julho de 2002, página A10).

\subsection{Análise das Entrevistas}

Foram realizadas entrevistas na Telefônica (em 17 de setembro de 2003), na ANATEL (em 13 de outubro de 2003) e contato com advogado indicado pelo CADE $^{19}$. Os roteiros de entrevista utilizados estão em anexo.

$\mathrm{Na}$ Telefônica a entrevista foi concedida pelo Vice-presidente Eduardo Navarro e na ANATEL foram entrevistados o Superintendente de Serviços Públicos Marcos Baffuto, auxiliado pelo Assessor Benedito Barbosa, e o Conselheiro José Leite Pereira Filho. O CADE

\footnotetext{
17 “Cláusula 30.1 - Os eventuais conflitos que possam surgir em matéria da aplicação e interpretação das normas da concessão serão resolvidos pela ANATEL no exercício da sua função de órgão regulador conforme prescrito nos artigos $8^{\circ}$ e 19 da Lei $n^{\circ} 9.472$, de 1997 , podendo a Concessionária recorrer ao procedimento da arbitragem disposto no presente Capítulo exclusivamente quando inconformada com a decisão da ANATEL relativa às seguintes matérias:

I - violação do direito da Concessionária à proteção de sua situação econômica, conforme prescrito no Capítulo XII;

(...)".

18 “Cláusula $26.5-(\ldots)$.

Parágrafo único - Não constitui motivo para a rescisão contratual a introdução ou a ampliação da competição entre os diversos prestadores do serviço objeto da concessão, sendo certo que a Concessionária assume a presente concessão ciente de que exercerá suas atividades sem qualquer reserva ou exclusividade de mercado".

${ }^{19}$ Conforme nota disposta no capítulo IV.
} 
indicou para a entrevista o advogado Marcelo Amorelli, atualmente na ANATEL.

A partir da análise das informações obtidas nas fontes secundárias e nas entrevistas notou-se que o modelo de privatização das telecomunicações no Brasil foi caracterizado fortemente pela universalização dos serviços e competição entre as operadoras do setor. $\mathrm{O}$ modelo previa, ainda, dois estágios no período pós-privatização (após o leilão de privatização), um de competição limitada (transição) e outro de competição total.

Eduardo Navarro comentou a existência de três interesses: o interesse público, representado e defendido pelo governo, por intermédio da agência reguladora, o interesse particular, que é o usuário do serviço, e o interesse do investidor (no caso as operadoras). $\mathrm{O}$ governo pretende garantir a universalização, o acesso de todos ao serviço; o interesse do investidor é ter lucro; e o usuário pretende ter liberdade de escolha, considerando que quanto maior o número de competidores, maior seu poder de barganha. A dificuldade, segundo ele, é fazer com que os três interesses sejam atendidos. Para garantir a universalização, há os contratos em regime de concessão, com obrigação de cumprimento de metas, sem as quais dificilmente uma empresa privada, com fins lucrativos, aceitaria atender os usuários das classes sociais mais baixas. Para que o usuário tenha liberdade de escolha há a inclusão da empresa-espelho na oferta de serviços e são previstas prerrogativas ao concessionário, como competição limitada no período da transição.

Comentou Benedito Barbosa:

Em 1997, a Lei Geral estabeleceu um modelo novo de Telecomunicação em nosso país, nós tínhamos um modelo estatal monopolista federal, eram empresas federais sobre o controle acionário da Telebrás. Com a Lei Geral de Telecomunicações, esse modelo passou a ser diferenciado, no sentido de que seria um modelo explorado pela iniciativa privada em ambiente de competição. Muito bem. Como se construiu esse modelo? Imaginou-se primeiro um período de transição, nós sairíamos de um estágio monopolista estatal, para um estágio de plena competição. Entre esses dois estágios nós teríamos um período de transição que seria marcado pelo 'duopólio', ou seja, uma competição ainda limitada, há duas empresas por segmento de serviços.

Quais são os segmentos de serviços que o novo modelo estabeleceu? No caso da telefonia fixa, o novo modelo estabeleceu a separação de serviços locais e serviços de longa distância.

A competição nos serviços de longa distância por meio do regime de 'duopólio', aconteceu imediatamente e era mais fácil de acontecer, haja vista a característica da rede de longa distância, aí já tem um aspecto técnico, que é o seguinte: a rede de longa distância não tem usuário diretamente vinculado a ela, quer dizer a rede da Embratel, por exemplo, nenhum de nós tem o seu telefone em casa ligado à rede da Embratel, nós temos nosso telefone ligados às concessionárias locais, através de suas centrais locais. Então, por essa característica técnica, foi mais fácil iniciar a competição no mercado de longa distância. Como não havia o problema técnico superou-se imediatamente esta etapa para ir diretamente para a competição do mercado, com a introdução, por exemplo, da primeira competidora em regime privado, que foi a Intelig.

Então, a Embratel, concessionária de longa distância, de telefonia fixa de longa 
distância, passou a ter imediatamente uma competidora dos seus serviços pela Intelig. Essa competição aos poucos veio tomando corpo, ganhando musculatura, e hoje a gente já sabe que, perfeitamente, existe guerra nos preços, a gente vê de vez em quando na mídia, as duas empresas disputando preço nas ligações nacionais e internacionais.

Bom, uma primeira parte no objetivo de alcançar a competição no serviço de telefonia fixa, foi conseguido através das ligações de longa distância, e aí surgiram, depois, as empresas de longa distância nacional dentro das regiões.

A Telemar na Região 1 - Plano Geral de Outorgas; a Brasil Telecom na Região 2 - Plano Geral de Outorgas; e a Telefônica na Região 3 - Plano Geral de Outorgas. Competindo nas ligações dentro das suas regiões com a Embratel e com a Intelig. Então isso acirrou um pouquinho mais as competições nos serviços de longa distância.

Barbosa comentou, ainda, as razões da divisão do país nas regiões de concessão. Como no Sistema Telebrás as concessões eram estaduais, optou-se por manter essa tradição. Além de preservar o modelo anteriormente adotado, haveria uma organização na prestação do serviço, evitando "canibalismo" empresarial.

Sobre o papel da ANATEL e do CADE na solução de questões da concorrência e de conflitos, Navarro afirmou notar, sim, na prática, uma sobreposição de atuação da agência e do conselho administrativo, muitas vezes em função da lentidão da agência reguladora em algumas situações, o que ocorre pela escassez de pessoal. Isso apesar da percepção de que as atuações dos dois órgãos estão bem delimitadas na legislação, com a ANATEL devendo fazer a instrução dos processos, papel que em outros setores compete à SEAE, e o CADE decidindo os conflitos.

Para a ANATEL, não há essa sobreposição. Baffuto vê claramente a separação prevista na Lei Geral de Telecomunicações ocorrendo nas decisões e ações do dia-a-dia. E afirma que compete à agência reguladora mediar tanto conflitos comerciais entre as prestadoras de serviços de telecomunicações que não envolvem qualquer violação da lei de defesa da concorrência quanto aqueles em que tal violação ocorre. Havendo infração de ordem econômica por parte de alguma prestadora de serviços de telecomunicações, seja ela concessionária ou autorizada, é papel da ANATEL averiguar o enquadramento da conduta nos artigos da Lei de Defesa da Concorrência, analisar o caso e encaminhar para posterior decisão do CADE.

Tanto a Telefônica quanto a ANATEL percebem a importância da negociação para a solução dos conflitos. Um aspecto importante a destacar é o comentário unânime de que a grande maioria das situações de conflito é resolvida pela negociação entre as partes, havendo, no máximo, uma mediação da agência reguladora. Os casos mais complexos, contudo, seriam os únicos a demandarem recursos à ANATEL, ao CADE ou mesmo à Justiça Comum. Para 
Navarro, no setor de telecomunicações, "embora exista muito conflito, o potencial de geração de conflito é infinito". E o fato de grande parte desses conflitos ser solucionada pela negociação pode contribuir com a diminuição do tempo despendido e o desgaste nas relações.

Sobre as variáveis básicas da negociação, o tempo é fator chave nas decisões dos órgãos (ANATEL ou CADE) ou mesmo nas sentenças judiciais, assim como as informações disponíveis e divulgadas pelas competidoras. Bafutto citou, inclusive, o caso do conflito para emissão de contas conjuntas, apresentado no capítulo III, como um caso de difícil solução em função de "problemas na assimetria de informações passadas pelas empresas concessionárias". Em termos de poder, a Telefônica acredita haver equivalência entre as operadoras, até pela atuação da agência reguladora equilibrando eventuais disparidades.

Para a solução de conflitos, nota-se muitas situações resolvidas pela negociação direta ou com a mediação do órgão regulador, o que não impede o recurso ao Poder Judiciário.

Para a Telefônica, as conseqüências mais graves do recurso à Justiça Comum são a lentidão na tomada de decisão, a ausência de conhecimento específico do assunto sobre o qual será proferida sentença, e a instabilidade jurídica, pois uma decisão da agência reguladora ou mesmo do CADE, ou até mesmo uma cláusula prevista em um contrato de concessão pode ser suspensa em um tribunal não especializado no assunto.

A ANATEL considera o recurso à Justiça Comum uma ameaça ao modelo regulatório do país, principalmente pela desconsideração da decisão da agência que deve regulamentar, fiscalizar e conceder o direito de atuação no setor de telecomunicações. O conselheiro José Leite Pereira Filho comentou a possibilidade de melhorar essa estrutura de recurso à ANATEL e ao Poder Judiciário, embora esse seja um fato que ocorre em todos os países. "O que eu vejo é uma tendência no mundo de quase como se fosse um quarto poder, para a regulação. Além dos três poderes ${ }^{20}$, você nota que os países desenvolvidos têm um quarto poder, que é o Poder Regulatório".

O Superintendente Bafutto comentou a utilização do termo "arbitragem" em três situações diferentes, dois dos quais bem definidos em termos regulatórios e um terceiro conceito confundível com a definição de mediação ${ }^{21}$. Há, portanto, a arbitragem prevista na legislação civil e nos contratos de concessão, aquela prevista nos contratos de interconexão, e a arbitragem feita como procedimento administrativo que, segundo o Superintendente de Serviços Públicos, "se confunde com a mediação".

\footnotetext{
${ }^{20}$ Os três Poderes a que se refere o Conselheiro da ANATEL são Poder Legislativo, Poder Executivo e Poder Judiciário, comentados no capítulo I.
} 
No caso do conflito entre Embratel e Telefônica, a agência reguladora teve atuação constante, principalmente ao impetrar recursos ao Poder Judiciário na tentativa de confirmar sua decisão de liberação da Telefônica para a prestação de serviços de chamadas de longa distância nacional e internacional pelo cumprimento antecipado das metas de qualidade e universalização. A decisão de alterar a forma de liberação da operadora para que a atuação acontecesse independente da decisão judicial acabou possibilitando a entrada da Telefônica no mercado de chamadas de longa distância nacional em julho de 2002.

Com essa decisão e o fim da disputa judicial, a Telefônica acabou ficando com atuação em dois regimes diferentes: é concessionária dos serviços de telefonia local na Região III e de telefonia de longa distância nacional para chamadas originadas no Estado de São Paulo (prestação do serviço em regime público), mas é autorizada (regime privado) para a prestação de serviços de longa distância nos outros estados do país.

Inicialmente, a ANATEL havia estipulado que a Telefônica deveria atuar em todos os serviços como concessionária, pois o contrato seria mantido, apenas com a retirada de restrições contratuais.

Para Eduardo Navarro, a solução dada foi melhor para a Telefônica, pois enquanto autorizada, a empresa passa a ter maior liberdade de atuação e não fica sujeita aos encargos das concessionárias (cumprimento de metas e dever de continuidade dos serviços).

Ao CADE coube decidir um pedido de liminar da Embratel para suspender a liberação da Telefônica argumentando haver prática anticompetitiva na cobrança das tarifas de interconexão, mas o CADE não concedeu tal liminar por considerar que as tarifas já estavam definidas há pelo menos três anos, não sendo necessária decisão urgente, por meio de liminar, e determinando que a decisão, ou melhor, a análise do caso, deveria ser feita pela agência reguladora.

A Telefônica afirma ter tentado negociar a liberação com a Embratel antes do início da disputa judicial, mas o acordo não teria sido viável porque a Embratel teria pedido "uma relação de concessões tão grande que era um negócio inviável". Para a operadora, o recurso ao Poder Judiciário não é a melhor forma de solução de conflitos no setor de telecomunicações por haver muitas peculiaridades e legislações específicas, que podem ser melhor analisadas e ponderadas pela agência reguladora.

A ANATEL considera-se satisfeita com o resultado do conflito de antecipação de metas da Telefônica porque a demora ocorreu nas decisões judiciais e não nos processos da

\footnotetext{
${ }^{21}$ Os conceitos de mediação e arbitragem como formas alternativas de solução de conflitos são apresentados no capítulo III do presente estudo.
} 
agência. $O$ modelo de privatização, com análise, fiscalização e decisão feitos pela agência reguladora funcionou perfeitamente, mas com a utilização da possibilidade de recurso ao Poder Judiciário acabou havendo o atraso na liberação.

A Telefônica mantém a posição de ter feito um investimento muito alto para conseguir a antecipação de dois anos, mas que com a disputa judicial acabou perdendo quase "um quarto" desses dois anos. A vantagem apontada pela prestadora foi a liberação para outros estados ter ocorrido no regime privado, pois a empresa realmente preferia atuar dessa forma, mas já havia sido avisada pela ANATEL de que teria que atuar como concessionária. $\mathrm{O}$ questionamento da Embratel acabou, segundo Navarro, propiciando essa vantagem à Telefônica.

O que o vice-presidente fez questão de ressaltar foi o desgaste para o modelo e mesmo para o investidor estrangeiro, que dificilmente esquecerá o ocorrido no momento da liberação quando da decisão por um novo investimento no país. Isso porque a Telefônica vê uma grande instabilidade jurídica a partir da possibilidade de recursos a diferentes esferas e órgãos como tentativa de reverter ou pelo menos adiar o cumprimento de regras já previamente definidas.

Para Navarro, caso houvesse nova situação como essa, a decisão da empresa iria se basear em antecipar ou não as metas, mas a forma de solução do conflito teria que ser basicamente a mesma: aguardar a decisão da agência reguladora e, caso houvesse recurso ao Poder Judiciário, aguardar a sentença transitada em julgado.

Como não foi possível a realização da entrevista na Embratel, e por não ter havido publicação nas fontes secundárias sobre a satisfação da concessionária da Região IV com o resultado desse conflito, não é possível verificar qual teria sido a opção adotada pela empresa caso o conflito ocorresse novamente. 


\section{CONSIDERAÇÕES FINAIS}

Após a análise dos dados e informações coletados, são feitas as considerações finais do estudo, bem como a indicação de suas limitações e possibilidades de estudos futuros.

O processo de privatização das telecomunicações no Brasil foi concebido dentro da tendência mundial de flexibilização de monopólios, preconizada pela OMC, e de desestatização de serviços públicos, inclusive pela dificuldade do Estado para continuar atendendo de forma eficiente setores tão diversos e complexos da economia.

Outros setores, antes também atuantes em uma estrutura de monopólio, como o de energia elétrica e de exploração de petróleo, passaram por processos semelhantes de privatização, com a transferência do Estado para o particular da prestação ou exploração do serviço, sem, contudo, invadir a área de atividades econômicas livremente exploradas pelos particulares.

Em 1995, com a Emenda Constitucional no 08, foi possível a concretização da liberação de setores até então restritos à atuação monopolista do Estado.

No setor de telecomunicações a privatização ocorreu dentro de um modelo de universalização e competição. Por universalização entende-se a definição de metas para a ampliação do atendimento e acesso da população ao serviço de telecomunicações. A competição foi prevista exatamente para substituição do regime de monopólio para a livre concorrência, com alternativas de empresas (operadoras) para que o usuário possa escolher aquela que mais o satisfaça.

A privatização das telecomunicações concretizou-se com as leis criadas em 1996 e 1997, inclusive com a criação da ANATEL, e com o leilão das empresas do Sistema Telebrás, ocorrido em julho de 1998.

A ANATEL foi concebida para fiscalizar e regulamentar o setor de telecomunicações e mediar conflitos entre operadoras e entre operadoras e usuários, além das relações de usuários e operadoras com o governo.

Para a privatização do Sistema Telebrás, o Brasil foi dividido em quatro regiões geográficas e dentro dessas regiões em setores por duas razões principais: manter a estrutura de divisão em Estados da prestação do serviço, como já ocorria na era monopolista, e garantir a atuação de empresas diferentes em cada região e sempre com pelo menos duas empresas em cada região. O serviço também foi dividido em atividades 
distintas, como Serviço Telefônico Fixo Comutado (STFC), o Serviço Telefônico Móvel, TV a Cabo, entre outros.

O foco do estudo é o STFC (Serviço Telefônico Fixo Comutado). Para essa atividade, as Regiões I, II e III contemplavam serviços de chamadas locais e de longa distância dentro da própria região. Em cada região houve a concessão a uma empresa e a autorização de prestação do serviço a outra empresa. Dessa forma, foi possível ter duas concorrentes no serviço de chamada local: a concessionária e a empresa-espelho (duopólio).

A principal diferença entre as duas formas de liberação dos serviços de telecomunicações está no regime de prestação do serviço. As concessionárias atuam em regime público, ou seja, estão sujeitas ao cumprimento de metas definidas pela agência reguladora e têm obrigações próprias de entidades de Direito Público, como universalização e continuidade do serviço. As empresas-espelho, por sua vez, recebem uma autorização para atuação em regime privado, livres, portanto, das metas e com maior liberdade de atuação. Em contrapartida, as concessionárias puderam manter a estrutura e a tradição das antigas empresas estatais na vida dos usuários.

Após o leilão de privatização das telecomunicações há dois períodos distintos: uma fase de transição do monopólio para a competição, com concorrência ainda limitada, caracterizada pelo regime de duopólio e mais perceptível na Região IV, e uma fase de competição total, com livre concorrência entre operadoras.

A concorrência no setor de chamadas locais tem sido, desde a privatização, significativamente menos intensa do que no setor de chamadas de longa distância nacionais e internacionais. Isso porque para completar essas últimas chamadas, o usuário precisa efetivamente escolher uma operadora, o que não ocorre nas chamadas locais (facilidade operacional em função da forma de conexão do usuário às redes).

Para a Região IV (chamadas de longa distância nacionais e internacionais), a Embratel recebeu a concessão e a Intelig recebeu a autorização para prestação de serviços de telecomunicações.

Visando ampliar a concorrência, o modelo de privatização previa, ainda, a possibilidade de liberação das concessionárias que cumprissem as metas de qualidade e universalização para a atuação em outros serviços e setores (Regiões) até 31 de dezembro de 2003. Tal liberação poderia ser obtida em 2002 caso a concessionária conseguisse cumprir as metas antecipadamente. 
O grau de intensidade de concorrência em um setor depende, basicamente, de cinco forças competitivas: a intensidade de rivalidade entre os concorrentes, a ameaça de novos entrantes, os produtos substitutos (no caso, serviços substitutos) e o poder de negociação de usuários e fornecedores.

Além da agência reguladora, que tem atuação específica em um setor, há, ainda, o Conselho Administrativo de Defesa Econômica (CADE) para assegurar a competitividade nos diferentes setores econômicos do país, punindo e prevenindo infrações à legislação de defesa da concorrência. A atuação do CADE conta com o suporte da SEAE e da SDE, embora no setor de telecomunicações o papel da SEAE seja desempenhado, conforme previsto na legislação, pela própria ANATEL.

A Telefônica foi a primeira concessionária do Brasil a cumprir todas as metas definidas pela ANATEL. Com o cumprimento das metas em 2001, a operadora conseguiu, em março de 2002, o certificado de liberação para prestação de serviços de longa distância nacional e internacional.

Por ter sido a primeira, a operadora enfrentou o fato de não haver, ainda, uma regulamentação pronta para disciplinar a forma como a liberação ocorreria. A princípio a ANATEL concedeu a liberação em regime de concessão, mediante aditivo no contrato inicial.

Tem início, então, o conflito entre Embratel e Telefônica, foco de análise do trabalho.

Como formas de solução de conflitos são apresentadas a negociação, a mediação, a arbitragem e o recurso ao Poder Judiciário.

$\mathrm{Na}$ negociação, as próprias partes conseguem definir os termos de um acordo para a solução do impasse.

Quando, porém, tal possibilidade torna-se inviável, seja por excesso de desconfiança ou mesmo por problemas de comunicação e relacionamento entre as partes, é preciso recorrer a um terceiro, não envolvido no conflito, para que possibilite a solução do conflito.

Na mediação, o terceiro atua meramente como conciliador, apenas auxiliando as partes a chegarem ao acordo.

$\mathrm{Na}$ arbitragem, assim como no recurso ao Poder Judiciário, cabe ao terceiro impor uma decisão. O terceiro é um agente privado, no caso da arbitragem, não podendo, portanto, decidir questões relacionadas a direitos indisponíveis, ou atua com poder 
coercitivo estatal, caso do recurso ao Poder Judiciário.

A arbitragem está prevista nos contratos de concessão do setor de telecomunicações como forma preferencial de solução de conflitos. Na agência reguladora nota-se, ainda, a utilização da arbitragem de duas outras formas distintas: para solução exclusiva dos conflitos relacionados a interconexão, conforme procedimento definido em regulamento geral específico (RGI), e a arbitragem enquanto procedimento administrativo usado para a solução de impasses entre operadoras, assemelhando-se ao conceito de mediação.

Quando a ANATEL certificou o cumprimento de metas da Telefônica, a Embratel ofereceu representação na agência reguladora e no CADE contra a liberação da Telefônica para atuação na Região IV. Indeferidos os pedidos nos dois órgãos, a Embratel conseguiu liminares na Justiça Comum impedindo a prestação do serviço de chamadas de longa distância nacional pela Telefônica.

O principal argumento da Embratel na Justiça Comum é o fato de não haver permissão legal para que uma mesma empresa receba duas concessões distintas, para atuação em serviços e regiões diferentes, e por não ter havido nova licitação para a nova concessão.

Em julho de 2002 a ANATEL resolveu liberar a Telefônica para a prestação do serviço de chamadas de longa distância nacional no regime privado, mediante autorização. Apesar da formalização como autorização, a Telefônica comprometeu-se a atuar como se concessionária fosse, auxiliando na universalização do serviço.

Com a privatização a incidência de conflitos no setor de telecomunicações se intensificou. Por isso, a tendência, com o ingresso no período de competição total, é um aumento ainda mais significativo da rivalidade entre as operadoras em função, entre outras coisas, da necessidade de uso compartilhado de estruturas físicas, como as redes de interconexão.

A partir de entrevistas e dados obtidos em fontes secundárias percebe-se a ocorrência de inúmeros conflitos, mas resolvidos, em sua maioria, pelas próprias partes envolvidas, no máximo com a mediação da ANATEL.

Somente os casos de conflitos mais complexos, em que as partes não lograram êxito na composição do litígio, é que se percebe a utilização de arbitragem, ingresso de processo administrativo na agência reguladora ou de ação na Justiça Comum.

A agência reguladora, representante do governo no papel de regular e fiscalizar o 
setor, manifesta ampla preferência pela solução amigável ou por decisão da própria ANATEL, pois decisões tomadas pelo Poder Judiciário enfraquecem o modelo de privatização adotado e, conseqüentemente, a própria agência, além do fato de que os órgãos da Justiça Comum carecem de conhecimento de especificidades técnicas do setor.

Partindo das informações fornecidas pela Telefônica tem-se que as operadoras também tendem a preferir essas soluções em razão do custo menor e da maior rapidez na decisão. Outro ponto importante é assegurar a estabilidade das decisões do setor, o que tende a garantir investimentos futuros de particulares.

No caso do conflito Embratel x Telefônica, nota-se uma atuação marcante da agência reguladora para assegurar a manutenção de sua decisão de liberação da Telefônica para atuação nos serviços de longa distância nacional. Chegou, inclusive, a obter cassação de liminar concedida à Embratel e manifestou sua reprovação do recurso ao Poder Judiciário por considerar essa uma atitude de descumprimento de decisão da agência reguladora de um setor privatizado.

Pela entrevista realizada na Telefônica constatou-se que a negociação entre as partes (mesmo que com a mediação da ANATEL) é a forma mais comum de solução de conflitos, até pelos benefícios trazidos a todos os envolvidos. É comum ter-se somente a homologação do acordo pela agência quando as partes atingem o consenso.

Para o caso em estudo foi tentada a composição entre as partes, mas, segundo a Telefônica tal acordo não foi concretizado em função de divergências de interesses dos quais nenhuma parte quis abdicar. A mediação da agência foi tentada, inclusive com decisão proferida. No entanto, o conflito persistiu.

A Telefônica conseguiu iniciar as operações nas chamadas de longa distância nacional somente em julho de 2002. Esse atraso gerou grande insatisfação na operadora, principalmente em termos de influência nas tomadas de decisão futuras sobre investimentos no país.

Somente com a apreciação do caso pelo Poder Judiciário é que se teve a decisão definitiva, em dezembro de 2002.

Para um setor em constante e crescente avanço tecnológico e considerando os altos investimentos da Telefônica para conseguir a antecipação de metas, tem-se que essa parte não saiu totalmente satisfeita com o resultado. A operadora admite ter sido benéfica a ela a decisão final da agência de conceder a prestação do serviço em regime de autorização, até pela liberdade de atuação. 
A agência reguladora sente-se satisfeita com o resultado, embora considere prejudicial ao modelo a demora na decisão final e o fato desta ter sido dada pelo Poder Judiciário e não pela ANATEL, que é a responsável, conforme definido em lei, por regulamentar e fiscalizar o setor e mediar conflitos entre os agentes nele atuantes.

Não foi possível estabelecer o grau de satisfação da Embratel com o resultado do processo por não ter sido realizada a entrevista nessa concessionária.

\section{Limitações e propostas de trabalho futuro}

A não realização da entrevista na Embratel impossibilitou a análise do grau de satisfação e as formas de solução de conflitos mais comuns na empresa (nas relações da empresa com outros clientes externos).

Cabe destacar que não é objetivo deste trabalho analisar a cadeia do setor de telecomunicações, portanto são desconsiderados para efeitos de análise os aspectos concernentes a fornecedores e usuários do serviço de telefonia. O foco da análise é mantido nas relações entre os concorrentes do setor após a privatização, mais especificamente nos conflitos surgidos no período pós-privatização, em que há aumento da concorrência, principalmente na prestação de serviços telefônicos para chamadas de longa distância nacional e internacional, com as antecipações de cumprimento de metas e liberações de concessionárias para a prestação de serviços diferenciados e em regiões geográficas diferentes, conforme previsto no Plano de Metas e no Plano de Outorgas.

É possível apontar a relevância de estudos futuros sobre a atuação da agência reguladora do setor de telecomunicações em relação às agências de outros setores, como energia elétrica e petróleo, inclusive para averiguação da funcionalidade dos modelos adotados e principais pontos favoráveis e negativos de cada uma dessas agências. Seria possível estabelecer uma forma de atuação comum, relacionada ao próprio contexto de desestatização, regulação e competição, característico do novo modelo de Estado, seguindo a tendência mundial de diminuição do aparelho administrativo estatal e de flexibilização de monopólios.

Outro ponto de grande relevância para futuros trabalhos é enfatizar as questões de regulação x concorrência em setores antes submetidos a regimes de monopólio, focando as atuações conjuntas do órgão de defesa da concorrência (CADE) e os demais órgãos criados para a regulação desses setores econômicos. Com isso, seria possível verificar 
condições favoráveis e pontos fracos dos modelos do ponto de vista de incremento da competitividade em setores essenciais. 


\section{BIBLIOGRAFIA}

ACUFF, Frank L. Como negociar qualquer coisa com qualquer pessoa em qualquer lugar do mundo. São Paulo: SENAC, 1998. 355p.

BERTALANFFY, L. V. General System Theory. Foundations, Development, Applications. Nova York: George Braziller, 1968.

BICUDO, M. A.; ESPOSITO, V. Pesquisa qualitativa em educação: um enfoque fenomenológico. Piracicaba: UNIMEP, 1994.

BRASIL. Constituição da República Federativa do Brasil, 1988. Diário Oficial da União, Poder Executivo, Brasília, DF, 1988.

BRASIL. Lei n ${ }^{0}$ 9.472, de 16 de julho de 1997. Diário Oficial da União, Poder Executivo, Brasília, DF, 1997.

BRASIL. Lei n ${ }^{0}$ 9.295, de 16 de julho de 1996. Diário Oficial da União, Poder Executivo, Brasília, DF, 1997.

BRASIL. Lei n ${ }^{\circ}$ 8.987, de 13 de fevereiro de 1995. Diário Oficial da União, Poder Executivo, Brasília, DF, 1997.

BRASIL. Lei no 8.977, de 06 de maio de 1995. Diário Oficial da União, Poder Executivo, Brasília, DF, 1997.

BRASIL. Lei ${ }^{\circ}$ 4.137, de 10 de julho de 1962. Diário Oficial da União, Poder Executivo, Brasília, DF, 1997.

BRASIL. Lei $\mathrm{n}^{\circ}$ 8.884, de 11 de junho de 1994. Diário Oficial da União, Poder Executivo, Brasília, DF, 1997.

BRASIL. Decreto n ${ }^{\circ} 2.534$, de 02 de abril de 1998. Diário Oficial da União, Poder Executivo, Brasília, DF, 03 de abril de 1998.

BRASIL. Decreto n 2.592, 1998. Diário Oficial da União, Poder Executivo, Brasília, DF, 03 de abril de 1998.

BRASIL. Decreto $\mathrm{n}^{\circ}$ 4.769, 27 de junho de 2003. Diário Oficial da União, Poder Executivo, Brasília, DF, 03 de abril de 1998.

BRASIL. Decreto $\mathrm{n}^{\mathrm{o}} 2.338$, de 07 de outubro de 1997. Diário Oficial da União, Poder Executivo, Brasília, DF, 03 de abril de 1998.

BRASIL. Resolução no 36, de 27 de maio de 1998. Diário Oficial da União, Poder Executivo, Brasília, DF, 03 de abril de 1998. 
COELHO, Fábio Ulhoa. Reforma do Estado e Direito Concorrencial. In: SUNDFELD, Calos Ari. Direito Administrativo Econômico. São Paulo: Malheiros, 2002, pp 190-199.

CRETELLA Jr, José. Manual de Direito Administrativo. Rio de Janeiro: Forense, 1998. 6.ed.

DARTIGUES, André. O que é a fenomenologia? São Paulo: Moraes, 1992. 3.ed. 174p.

DI PIETRO, Maria Sylvia Zanella. Direito Administrativo. São Paulo: Atlas, 1998. 9.ed.

DI PIETRO, Maria Sylvia Zanella. Parcerias na Administração Pública - Concessão, Permissão, Franquia, Terceirização e Outras Formas. São Paulo: Atlas, 1999.

FORGHIERI, Y. C. Psicologia fenomenológica: fundamentos, método e pesquisas. São Paulo: Pioneira, 1993.

GIANESI, Irineu G. N.; CORRÊA, Henrique Luiz. Administração estratégica de serviços operações para a satisfação do cliente. São Paulo: Atlas, 1994. 233p.

GROTTI, Dinorá Adelaide Musetti. Teoria dos Serviços Públicos e sua Transformação. In: SUNDFELD, Calos Ari. Direito Administrativo Econômico. São Paulo: Malheiros, 2002, pp $39-71$.

HAMPTON, D. R. Administração - Comportamento Organizacional. São Paulo: McGrawHill/Makron Books, 1991.

JUSTEN FILHO, Marçal. Teoria Geral das concessões de serviço público. São Paulo: Dialética, 2003. 654p.

LEBEL, P. L'art de la négociation. Paris: Les Éditions D’Organisation, 1984.

LEHFELD, Lucas de Souza. As Novas Tendências na Regulamentação do Sistema de Telecomunicações pela Agência Nacional de Telecomunicações - ANATEL. Dissertação de Mestrado apresentada na Faculdade de História, Direito e Serviço Social da Universidade Estadual Paulista. São Paulo: 2001. 201p.

LEWICKI, R.; LITTERER, J. A.. Negotiation. New York: McGraw-Hill, 1994. 2.ed. 478p.

MARQUES NETO, Floriano Azevedo. A Nova Regulação Estatal e as Agências Independentes. In: SUNDFELD, Calos Ari. Direito Administrativo Econômico. São Paulo: Malheiros, 2002, pp 72-98.

MARTINELLI, Dante Pinheiro. Negociação empresarial - Enfoque sistêmico e visão estratégica. São Paulo: Manole, 2002. 262p.

MARTINELLI, Dante Pinheiro; ALMEIDA, Ana Paula de. Negociação e Solução de Conflitos - Do impasse ao ganha-ganha através do melhor estilo. São Paulo: Atlas, 1998. $159 \mathrm{p}$.

MAXIMIANO, Antonio C. Amaru. Teoria Geral da Administração. São Paulo: Atlas, 2000. 
MEIRELLES, Hely Lopes. Direito Administrativo Brasileiro. São Paulo: Malheiros, 1998. 23.ed.

MELLO, Celso Antônio Bandeira de. Prestação de serviço público e Administração Indireta. São Paulo: RT, 1987.

MICHELINI, Luciana Helena. Análise fenomenológica dos principais aspectos do processo de negociação para criação da companhia de Bebidas das Américas (AmBev). Trabalho de conclusão de curso apresentado na Faculdade de Economia, Administração e Contabilidade da Universidade de São Paulo, Campus Ribeirão Preto. 2001.

NUSDEO, Ana Maria de Oliveira. Agências Reguladoras e Concorrência. In: SUNDFELD, Calos Ari. Direito Administrativo Econômico. São Paulo: Malheiros, 2002, pp 159-189.

PORTER, Michael. Estratégia Competitiva. Rio de Janeiro: Campus, 1997. 7.ed. 362p.

PORTER, Michael. Competição - Estratégias competitivas essenciais. Rio de Janeiro: Campus, 1999. 7.ed. 515p.

RICHARDSON, Roberto Jarry. Pesquisa Social. Métodos e Técnicas. São Paulo: Atlas, 1999.334p.

SALOMÃO FILHO, Calixto. Regulação da atividade econômica - princípios e fundamentos jurídicos. São Paulo: Malheiros, 2001. 159p.

SALOMÃO FILHO, Calixto. Regulação e concorrência (estudos e pareceres). São Paulo: Malheiros, 2002. 208p.

SCHODERBEK, Peter P., SCHODERBEK, Charles G., KEFALAS, Asterios, G. Management Systems - Conceptual Considerations. EUA: Irwin, 1990. 458p.

SELLTIZ et al. Métodos de Pesquisa nas Relações Sociais - Medidas na Pesquisa Social. São Paulo: EPU, 1987. 2vol. 133p.

SPARKS, D. B. A Dinâmica da Negociação Efetiva: Como Ser Bem-sucedido através de uma Abordagem Ganha-ganha. São Paulo: Nobel, 1992.

SUNDFELD, Carlos Ari. Introdução à Agências Reguladoras. In: SUNDFELD, Calos Ari. Direito Administrativo Econômico. São Paulo: Malheiros, 2002, pp 17-36.

TURCZYN, Sidnei. O Direito da Concorrência e os Serviços Privatizados. In: SUNDFELD, Calos Ari. Direito Administrativo Econômico. São Paulo: Malheiros, 2002, pp 200-210.

VENTURA, Carla Aparecida Arena. Contratos de Concessão entre o Estado Brasileiro e Empresas Transnacionais de Telecomunicações. Dissertação de Mestrado apresentada na Faculdade de História, Direito e Serviço Social da Universidade Estadual Paulista, São Paulo, 2001.

VIEIRA, Valter Afonso. As tipologias, variações e características da pesquisa de Marketing. 
Revista da FAE, Curitiba, v.5, n.1, p.61-70, jan./abr. 2002.

WOHLERS, Márcio; OLIVA, Rafael. Desempenho Recente das Telecomunicações no Brasil. In: WOHLERS, Márcio; PLAZA, Crisanto. Informe Anual de Telecomunicações e Tecnologias da Informação. São Paulo: CELAET, 2000, p. 59-114. 
ANEXOS 


\section{Roteiro para Entrevista \\ ANATEL C CADE}

Dados de caracterização

Razão social

Sede

Setor de atuação

Área de atuação

Missão

Valores

Objetivos de atuação

\section{Qualificação do entrevistado}

Nome

Cargo

Formação

Tempo de trabalho na organização

Experiência no setor de telecomunicações

\section{Estrutura interna da organização}

Níveis hierárquicos

Via hierárquica

Processo de tomada de decisão

\section{Atuação conjunta entre ANATEL e CADE}

Viabilidade prática

Sobreposição prática?

Casos de conflitos solucionados conjuntamente

Visão/percepção da atuação do "outro"

Formas de solução/adoção de medidas para manutenção da ordem econômica

Modelo de privatização do setor de telecomunicações - favorece livre concorrência?

Papel/importância na regulação da concorrência e solução de conflitos?

\section{Período pós-privatização}

Características? Importância?

Atuação de cada órgão?

Vantagens e desvantagens?

Preparação?

\section{Atuação em situações de conflitos}

Conflitos entre operadoras

Conflitos entre usuários e operadoras

Formas de solução preferidas? Negociação? Arbitragem?

Grau de familiaridade/utilização da Mediação

Grau de familiaridade/utilização da Arbitragem

Posição sobre cumprimento antecipado de metas da Telefônica

Legalidade?

Impactos no mercado

Favorável/benéfico à competitividade? 


\section{Visão do conflito Embratel x Telefônica}

Posição da Embratel

Posição da Telefônica

Solução encontrada - foi a mais vantajosa?

Possibilidade de utilização da arbitragem prevista no contrato de concessão: por que não?

Recurso ao Poder Judiciário (Embratel)?

Visão sobre papel/participação no caso em estudo

ANATEL

CADE 


\section{Roteiro para entrevista Embratel e Telefônica}

\section{Dados de caracterização}

Razão social

Sede

Setor de atuação

Área de atuação

Missão

Valores

Objetivos de atuação

\section{Qualificação do entrevistado}

Nome

Cargo

Formação

Tempo de trabalho na organização

Experiência no setor de telecomunicações

\section{Estrutura interna da organização}

Níveis hierárquicos

Via hierárquica

Processo de tomada de decisão

\section{Atuação conjunta entre ANATEL e CADE}

Viabilidade prática

Sobreposição prática?

Visão/percepção da atuação desses órgãos na solução de impasses

Modelo de privatização do setor de telecomunicações - favorece livre concorrência?

Papel/importância na regulação da concorrência e solução de conflitos?

\section{Período pós-privatização}

Características? Importância?

Atuação de cada órgão?

Vantagens e desvantagens?

Preparação?

Posição sobre cumprimento antecipado de metas da Telefônica (para Embratel)

Legalidade?

Impactos no mercado e na Embratel

Favorável/benéfico à competitividade?

\section{Visão do conflito Embratel $x$ Telefônica}

Posição da Embratel

Posição da Telefônica

Solução encontrada - foi a mais vantajosa?

Qual o grau de satisfação com o resultado?

Impacto das variáveis básicas: tempo, poder e informação para cada parte Hoje: adotariam outra opção de solução (arbitragem, negociação, CADE?) 
Visão sobre papel/participação no caso em estudo

ANATEL

CADE

Outra parte

Situações de conflito em geral

Como a empresa lida com tais conflitos (internos, com concorrentes, usuários, ANATEL)?

Forma de solução preferida?

Satisfação (geral) com os resultados?

Negociação é favorável? Arbitragem (contrato de concessão)? Poder Judiciário?

Grau de familiaridade/utilização da Mediação

Grau de familiaridade/utilização da Arbitragem 


\section{DECRETO No 2.592, DE 15 DE MAIO DE 1998}

Aprova o Plano Geral de Metas para a Universalização do Serviço Telefônico Fixo Comutado Prestado no Regime Público.

O PRESIDENTE DA REPÚBLICA, no uso das atribuições que lhe confere o art. 84, inciso IV, da Constituição, e tendo em vista o disposto na Lei no 9.472, de 16 de julho de 1997.

\section{DECRETA:}

Art. $1^{\circ}$ Fica aprovado, na forma do Anexo a este Decreto, o Plano Geral de Metas para a Universalização do Serviço Telefônico Fixo Comutado Prestado no Regime Público.

Art. $2^{\circ}$ Este Decreto entra em vigor na data de sua publicação.

Brasília, 15 de maio de $1998 ; 177^{\circ}$ da Independência e $110^{\circ}$ da República.

FERNANDO HENRIQUE CARDOSO

Luiz Carlos Mendonça de Barros 


\title{
A N E X O
}

\section{PLANO GERAL DE METAS PARA A UNIVERSALIZAÇÃO DO SERVIÇO TELEFÔNICO FIXO COMUTADO PRESTADO NO REGIME PÚBLICO}

\author{
Capítulo I \\ Das Disposições Gerais
}

\begin{abstract}
Art. $1^{\circ}$ Para efeito deste Plano, entende-se por universalização o direito de acesso de toda pessoa ou instituição, independentemente de sua localização e condição sócio-econômica, ao Serviço Telefônico Fixo Comutado destinado ao uso do público em geral, prestado no regime público, conforme definição do art. $1^{\circ}$ do Plano Geral de Outorgas, aprovado pelo Decreto $\mathrm{n}^{\circ}$ 2.534, de 2 de abril de 1998, bem como a utilização desse serviço de telecomunicações em serviços essenciais de interesse público, nos termos do art. 79 da Lei $n^{\circ} 9.472$, de 16 de julho de 1997, e mediante o pagamento de tarifas estabelecidas na regulamentação específica.
\end{abstract}

Art. $2^{\circ}$ Este Plano estabelece as metas para a progressiva universalização do Serviço Telefônico Fixo Comutado prestado no regime público, a serem cumpridas pelas Concessionárias do serviço, nos termos do art. 80, da Lei n 9.472, de 1997.

$\S 1^{\mathrm{o}}$ Todos os custos relacionados com o cumprimento das metas previstas neste plano serão suportados, exclusivamente, pelas Concessionárias por elas responsáveis, nos termos fixados nos respectivos contratos de concessão, observado o disposto no $\S 2^{\circ}$ do art. $4^{\circ}$.

$\S 2^{\circ}$ A Agência Nacional de Telecomunicações - ANATEL, em face de avanços tecnológicos e de necessidades de serviços pela sociedade, poderá propor a revisão do conjunto de metas que objetivam a universalização do serviço, observado o disposto nos contratos de concessão, bem como propor metas complementares ou antecipação de metas estabelecidas neste Plano, a serem cumpridas pelas prestadoras do Serviço Telefônico Fixo Comutado, definindo, nestes casos, fontes para seu financiamento, nos termos do art. 81 da Lei n ${ }^{\circ}$ 9.472, de 1997.

$\S 3^{\circ}$ As metas apresentadas neste Plano serão detalhadas, por Concessionária, nos respectivos contratos de concessão.

Art. $3^{\circ}$ Para efeitos deste Plano são adotadas as definições constantes da regulamentação, em especial as seguintes:

I - Serviço Telefônico Fixo Comutado é o serviço de telecomunicações que, por meio da transmissão de voz e de outros sinais, destina-se à comunicação entre pontos fixos determinados, utilizando processos de telefonia;

II - Telefone de Uso Público (TUP) é aquele que permite, a qualquer pessoa, utilizar, por meio de acesso de uso coletivo, o Serviço Telefônico Fixo Comutado, independentemente de assinatura ou inscrição junto à prestadora;

III - Localidade é toda a parcela circunscrita do território nacional que possua um aglomerado permanente de habitantes, caracterizada por um conjunto de edificações, permanentes e adjacentes, formando uma área continuamente construída com arruamentos reconhecíveis, ou dispostas ao longo de uma via de comunicação, tais como Capital Federal, Capital Estadual, Cidade, Vila, Aglomerado Rural e Aldeia; 
IV - Estabelecimentos de Ensino Regular são os estabelecimentos de Educação Escolar, públicos ou privados, conforme disposto na Lei $\mathrm{n}^{\circ}$ 9.394, de 20 de dezembro de 1996;

V - Instituição de Saúde é toda a instituição, pública ou privada, que preste, no mínimo, assistência ambulatorial e seja atendida por, pelo menos, um profissional de saúde de nível superior;

VI - Acessos Instalados são o conjunto formado pelo número total de acessos em serviço, inclusive os destinados ao uso coletivo, mais os acessos que, embora não ativados, disponham de todas as facilidades necessárias à entrada em serviço.

\section{Capítulo II}

Das Metas de Acessos Individuais

Art. $4^{\circ}$ As Concessionárias do Serviço Telefônico Fixo Comutado deverão:

I - ofertar, até o final dos anos de 1999, 2000 e 2001, por Unidade da Federação, as quantidades de Acessos Instalados constantes do Anexo I;

II - implantar o Serviço Telefônico Fixo Comutado, com acessos individuais, conforme a seguir:

a) até 31 de dezembro de 2001, em todas as localidades com mais de mil habitantes;

b) até 31 de dezembro de 2003, em todas as localidades com mais de seiscentos habitantes;

c) até 31 de dezembro de 2005 , em todas as localidades com mais de trezentos habitantes.

III - atender às solicitações de acesso individual, nas localidades com Serviço Telefônico Fixo Comutado, nos seguintes prazos máximos:

a) a partir de 31 de dezembro de 2001, em quatro semanas;

b) a partir de 31 de dezembro de 2002, em três semanas;

c) a partir de 31 de dezembro de 2003 , em duas semanas;

d) a partir de 31 de dezembro de 2004, em uma semana.

$\S 1^{\circ}$ A Concessionária que, a qualquer tempo, até 31 de dezembro de 2001 , demonstre estar atendendo a todas as solicitações de acesso individual, no prazo máximo estabelecido na alínea "a" do inciso III deste artigo, estará desobrigada das metas constantes dos seus respectivos contratos de concessão, correspondentes àquelas estabelecidas no inciso I deste artigo.

$\S 2^{\circ}$ A ANATEL poderá, excepcionalmente, propor fontes adicionais de financiamento para a parcela dos custos não recuperável pela exploração eficiente dos serviços referentes às metas indicadas nas alíneas "b" e "c" do inciso II deste artigo.

Art. $5^{\circ}$ Em localidades com Serviço Telefônico Fixo Comutado, com acessos individuais, a Concessionária deverá:

I - dar prioridade às solicitações de acesso individual dos Estabelecimentos de Ensino Regular e das Instituições de Saúde; 
II - tornar possível a utilização gratuita do Serviço Telefônico Fixo Comutado para comunicação com serviços de emergência existentes para a localidade;

III - tornar disponíveis acessos individuais para Estabelecimentos de Ensino Regular e Instituições de Saúde, objetivando permitir-lhes comunicação com redes de computadores, mediante utilização do próprio Serviço Telefônico Fixo Comutado ou da rede que lhe dá suporte.

Parágrafo único. As obrigações previstas nos incisos I e III deste artigo deverão ser cumpridas, a partir de 31 de dezembro de 1999, no prazo máximo de uma semana, após a solicitação da entidade.

Art. $6^{\circ}$ A partir de 31 de dezembro de 1999, em localidades com Serviço Telefônico Fixo Comutado, com acessos individuais, a Concessionária deverá assegurar condições de acesso ao serviço para deficientes auditivos e da fala, que disponham da aparelhagem adequada à sua utilização, observando as seguintes disposições:

I - tornar disponível centro de atendimento para intermediação da comunicação;

II - atender às solicitações de acesso individual, nos seguintes prazos máximos:

a) a partir de 31 de dezembro de 1999, em doze semanas;

b) a partir de 31 de dezembro de 2000 , em seis semanas;

c) a partir de 31 de dezembro de 2001 , em três semanas;

d) a partir de 31 de dezembro de 2002, em duas semanas;

e) a partir de 31 de dezembro de 2003, em uma semana.

\section{Capítulo III}

Das Metas de Acessos Coletivos

Art. $7^{\circ}$ Nas localidades com Serviço Telefônico Fixo Comutado com acessos individuais as Concessionárias deverão:

I - ativar, até o final dos anos de 1999, 2000 e 2001, por Unidade da Federação, as quantidades de Telefones de Uso Público constantes do Anexo II;

II - ativar, por Unidade da Federação, Telefones de Uso Público em quantidades que respeitem as condições a seguir:

a) a partir de 31 de dezembro de 2003, a densidade de Telefones de Uso Público deverá ser igual ou superior a 7,5 TUP/1000 habitantes e a relação percentual de Telefones de Uso Público pelo total de Acessos Instalados, igual ou superior a dois vírgula cinco por cento;

b) a partir de 31 de dezembro de 2005, a densidade de Telefones de Uso Público deverá ser igual ou superior a 8,0 TUP/1000 habitantes e a relação percentual de Telefones de Uso Público pelo total de Acessos Instalados, igual ou superior a três por cento;

Parágrafo único. A ativação dos Telefones de Uso Público deverá ocorrer de forma que, em toda a localidade, inclusive nas áreas de urbanização precária, existam, distribuídos territorialmente de maneira uniforme, pelo menos três Telefones de Uso Público por grupo de mil habitantes. 
Art. $8^{\circ}$ Nas localidades com Serviço Telefônico Fixo Comutado com acessos individuais, a Concessionária deverá assegurar a disponibilidade de acesso a Telefone de Uso Público, nas seguintes distâncias máximas, de qualquer ponto dentro dos limites da localidade:

I - a partir de 31 de dezembro de 1999, oitocentos metros;

II - a partir de 31 de dezembro de 2001, quinhentos metros;

III - a partir de 31 de dezembro de 2003, trezentos metros.

Parágrafo único. A partir de 31 de dezembro de 1999, do total de Telefones de Uso Público em serviço, em cada localidade, no mínimo cinqüenta por cento deverão estar instalados em locais acessíveis ao público vinte e quatro horas por dia, com capacidade de originar e receber chamadas locais e de longa distância nacional, sendo que, pelo menos, metade destes deverá, adicionalmente, ter capacidade de originar e receber chamadas de longa distância internacional.

Art. $9^{\circ}$ A Concessionária do Serviço Telefônico Fixo Comutado na modalidade Local deverá, nas localidades onde o serviço estiver disponível, ativar Telefones de Uso Público nos Estabelecimentos de Ensino Regular e em Instituições de Saúde, observados os critérios estabelecidos na regulamentação.

Parágrafo único. As solicitações deverão ser atendidas nos seguintes prazos máximos:

I - a partir de 31 de dezembro de 1999, em oito semanas;

II - a partir de 31 de dezembro de 2000, em quatro semanas;

III - a partir de 31 de dezembro de 2001, em duas semanas;

IV - a partir de 31 de dezembro de 2003, em uma semana.

Art. 10. A Concessionária do Serviço Telefônico Fixo Comutado na modalidade Local deverá assegurar que, nas localidades onde o serviço estiver disponível, pelo menos dois por cento dos Telefones de Uso Público sejam adaptados para uso por deficientes auditivos e da fala e para os que utilizam cadeira de rodas, mediante solicitação dos interessados, observados os critérios estabelecidos na regulamentação, inclusive quanto à sua localização e destinação.

Parágrafo único. As solicitações de que trata o caput deverão ser atendidas nos prazos máximos a seguir:

I - a partir de 31 de dezembro de 1999, em oito semanas;

II - a partir de 31 de dezembro de 2000, em quatro semanas;

III - a partir de 31 de dezembro de 2001, em duas semanas;

IV - a partir de 31 de dezembro de 2003, em uma semana. 
Art. 11. Até 31 de dezembro de 1999, as localidades atendidas somente com acessos coletivos do Serviço Telefônico Fixo Comutado deverão dispor de pelo menos um Telefone de Uso Público, instalado em local acessível vinte e quatro horas por dia e capaz de originar e receber chamadas de longa distância nacional e internacional.

Art. 12. Cada localidade ainda não atendida pelo Serviço Telefônico Fixo Comutado deverá dispor de pelo menos um Telefone de Uso Público instalado em local acessível vinte e quatro horas por dia, com capacidade de originar e receber chamadas de longa distância nacional e internacional, observado o seguinte cronograma:

I - até 31 de dezembro de 1999, todas as localidades com mais de mil habitantes;

II - até 31 de dezembro de 2001, todas as localidades com mais de seiscentos habitantes;

III - até 31 de dezembro de 2003, todas as localidades com mais de trezentos habitantes;

IV - até 31 de dezembro de 2005, todas as localidades com mais de cem habitantes;

$\S 1^{\circ}$ A responsabilidade pelo cumprimento do disposto neste artigo, para localidade situada a distância geodésica igual ou inferior a trinta quilômetros de outra, atendida com Serviço Telefônico Fixo Comutado com acessos individuais, será da Concessionária do serviço na modalidade Local.

$\S 2^{\circ}$ A responsabilidade pelo cumprimento do disposto neste artigo, para localidade situada a distância geodésica superior a trinta quilômetros de outra, atendida com Serviço Telefônico Fixo Comutado com acessos individuais, será da Concessionária de Longa Distância Nacional e Internacional, a quem incumbirá, ainda, o atendimento às populações situadas em regiões remotas ou de fronteira. 
A N E X O I

PLANO GERAL DE METAS PARA UNIVERSALIZAÇÃO DO SERVIÇO TELEFÔNICO FIXO COMUTADO

Acessos Instalados (mil)

\begin{tabular}{|c|c|c|c|}
\hline \multirow{2}{*}{$\begin{array}{l}\text { UNIDADE DA } \\
\text { FEDERAÇÃO }\end{array}$} & \multicolumn{3}{|c|}{ ANO } \\
\hline & 1999 & 2000 & 2001 \\
\hline RORAIMA & 42 & 46 & 49 \\
\hline AMAPÁ & 56 & 62 & 68 \\
\hline ACRE & 66 & 79 & 93 \\
\hline AMAZONAS & 237 & 284 & 336 \\
\hline RONDÔNIA & 178 & 214 & 253 \\
\hline PARÁ & 431 & 518 & 613 \\
\hline TOCANTINS & 75 & 90 & 105 \\
\hline SERGIPE & 131 & 158 & 186 \\
\hline CEARÁ & 695 & 731 & 756 \\
\hline PARAÍBA & 260 & 294 & 328 \\
\hline BAHIA & 1077 & 1294 & 1530 \\
\hline RIO GRANDE DO NORTE & 231 & 278 & 329 \\
\hline PERNAMBUCO & 625 & 745 & 874 \\
\hline PIAUÍ & 190 & 227 & 268 \\
\hline ALAGOAS & 191 & 228 & 267 \\
\hline MARANHÃO & 256 & 308 & 364 \\
\hline SÃO PAULO & 8167 & 9598 & 11098 \\
\hline RIO DE JANEIRO & 2983 & 3427 & 3876 \\
\hline MINAS GERAIS & 2706 & 3056 & 3397 \\
\hline ESPÍRITO SANTO & 436 & 511 & 588 \\
\hline PARANÁ & 1572 & 1787 & 2000 \\
\hline SANTA CATARINA & 851 & 961 & 1067 \\
\hline RIO GRANDE DO SUL & 1623 & 1861 & 2102 \\
\hline DISTRITO FEDERAL & 716 & 790 & 858 \\
\hline GOIÁS & 678 & 746 & 809 \\
\hline MATO GROSSO & 301 & 337 & 372 \\
\hline MATO GROSSO DO SUL & 326 & 370 & 414 \\
\hline TOTAL BRASIL & 25100 & 29000 & 33000 \\
\hline
\end{tabular}


A N E X O II

PLANO GERAL DE METAS PARA UNIVERSALIZAÇÃO DO SERVIÇO TELEFÔNICO FIXO COMUTADO

Telefones de Uso Público (mil)

\begin{tabular}{|c|c|c|c|}
\hline \multirow{2}{*}{$\begin{array}{c}\text { UNIDADE DA } \\
\text { FEDERAÇÃ் }\end{array}$} & \multicolumn{3}{|c|}{ ANO } \\
\cline { 2 - 4 } & $\mathbf{1 9 9 9}$ & $\mathbf{2 0 0 0}$ & $\mathbf{2 0 0 1}$ \\
\hline RORAIMA & 1,3 & 1,5 & 1,8 \\
\hline AMAPÁ & 1,6 & 1,9 & 2,2 \\
\hline ACRE & 1,7 & 2,1 & 2,6 \\
\hline AMAZONAS & 7,6 & 9,7 & 12,4 \\
\hline RONDÔNIA & 4,0 & 5,4 & 7,2 \\
\hline PARÁ & 13,6 & 18,6 & 25,5 \\
\hline TOCANTINS & 3,3 & 4,2 & 5,3 \\
\hline SERGIPE & 4,5 & 5,9 & 7,8 \\
\hline CEARÁ & 28,2 & 33,3 & 39,4 \\
\hline PARAÍBA & 10,5 & 13,3 & 16,8 \\
\hline BAHIA & 41,9 & 52,8 & 66,5 \\
\hline RIO GRANDE DO NORTE & 9,2 & 11,4 & 14,1 \\
\hline PERNAMBUCO & 36,1 & 41,0 & 46,6 \\
\hline PIAUÍ & 7,8 & 10,2 & 13,3 \\
\hline ALAGOAS & 7,7 & 10,1 & 13,2 \\
\hline MARANHÃO & 10,1 & 14,5 & 20,9 \\
\hline SÃO PAULO & 217,5 & 242,9 & 271,3 \\
\hline RIO DE JANEIRO & 84,6 & 92,5 & 101,1 \\
\hline MINAS GERAIS & 62,7 & 75,9 & 91,8 \\
\hline ESPÍRITO SANTO & 12,8 & 14,9 & 17,3 \\
\hline PARANÁ & 35,8 & 42,2 & 49,7 \\
\hline SANTA CATARINA & 20,1 & 23,9 & 28,4 \\
\hline RIO GRANDE DO SUL & 39,0 & 46,4 & 55,2 \\
\hline DISTRITO FEDERAL & 11,9 & 14,1 & 16,8 \\
\hline GOIÁS & 21,4 & 24,4 & 27,9 \\
\hline MATO GROSSO & 10,7 & 12,7 & 15,1 \\
\hline MATO GROSSO DO SUL & 7,6 & 9,2 & 11,1 \\
\hline TOTAL BRASIL & $\mathbf{7 1 3 , 2}$ & $\mathbf{8 3 5 , 0}$ & $\mathbf{9 8 1 , 3}$ \\
\hline & & & \\
\hline
\end{tabular}




\section{AGÊNCIA NACIONAL DE TELECOMUNICAÇõES}

\section{RESOLUÇÃO No 26 , DE 27 DE MAIO DE 1998}

Aprova o os modelos de Contratos de Concessão para a Prestação do Serviço Telefônico Fixo Comutado nas modalidades Local, Longa Distância Nacional e Longa Distância Internacional.

O CONSELHO DIRETOR DA AGÊNCIA NACIONAL DE TELECOMUNICAÇÕES - ANATEL, no uso de suas atribuições e tendo em vista o disposto no art. 22, da Lei no 9.472, de 16 de julho de 1997, e

CONSIDERANDO os comentários recebidos decorrentes da Consulta Pública nº 014, de 12 de março de 1998 - Modelo de Contrato de Concessão para Prestação do Serviço Telefônico Fixo Comutado no Regime Público, publicada no Diário Oficial de 13 de março de 1998, resolve:

Art. $1^{\circ}$ Aprovar os modelos de Contrato de Concessão para a Prestação do Serviço Telefônico Fixo Comutado nas modalidades Local, Longa Distância Nacional e Longa Distância Internacional, em anexo.

Art. $2^{\circ}$ Esta Resolução entra em vigor na data de sua publicação.

RENATO NAVARRO GUERREIRO

Presidente 


\section{A N EXOI}

PLANO GERAL DE METAS PARA UNIVERSALIZAÇÃO DO SERVIÇO TELEFÔNICO FIXO COMUTADO

Acessos Instalados (mil)

\begin{tabular}{|c|c|c|c|}
\hline \multirow{2}{*}{$\begin{array}{c}\text { UNIDADE DA } \\
\text { FEDERAÇÃ் }\end{array}$} & \multicolumn{3}{|c|}{ ANO } \\
\cline { 2 - 4 } & $\mathbf{1 9 9 9}$ & $\mathbf{2 0 0 0}$ & $\mathbf{2 0 0 1}$ \\
\hline RORAIMA & 42 & 46 & 49 \\
\hline AMAPÁ & 56 & 62 & 68 \\
\hline ACRE & 66 & 79 & 93 \\
\hline AMAZONAS & 237 & 284 & 336 \\
\hline RONDÔNIA & 178 & 214 & 253 \\
\hline PARÁ & 431 & 518 & 613 \\
\hline TOCANTINS & 75 & 90 & 105 \\
\hline SERGIPE & 131 & 158 & 186 \\
\hline CEARÁ & 695 & 731 & 756 \\
\hline PARAÍBA & 260 & 294 & 328 \\
\hline BAHIA & 1077 & 1294 & 1530 \\
\hline RIO GRANDE DO NORTE & 231 & 278 & 329 \\
\hline PERNAMBUCO & 625 & 745 & 874 \\
\hline PIAUÍ & 190 & 227 & 268 \\
\hline ALAGOAS & 191 & 228 & 267 \\
\hline MARANHÃO & 256 & 308 & 364 \\
\hline SÃO PAULO & 8167 & 9598 & 11098 \\
\hline RIO DE JANEIRO & 2983 & 3427 & 3876 \\
\hline MINAS GERAIS & 2706 & 3056 & 3397 \\
\hline ESPÍRITO SANTO & 436 & 511 & 588 \\
\hline PARANÁ & 1572 & 1787 & 2000 \\
\hline SANTA CATARINA & 851 & 961 & 1067 \\
\hline RIO GRANDE DO SUL & 1623 & 1861 & 2102 \\
\hline DISTRITO FEDERAL & 716 & 790 & 858 \\
\hline GOIÁS & 678 & 746 & 809 \\
\hline MATO GROSSO & 301 & 337 & 372 \\
\hline MATO GROSSO DO SUL & 326 & 370 & 414 \\
\hline TOTAL BRASIL & $\mathbf{2 5 1 0 0}$ & $\mathbf{2 9 0 0 0}$ & $\mathbf{3 3 0 0 0}$ \\
\hline & & & \\
\hline
\end{tabular}


A N E X O II

PLANO GERAL DE METAS PARA UNIVERSALIZAÇÃO DO SERVIÇO TELEFÔNICO FIXO COMUTADO

Telefones de Uso Público (mil)

\begin{tabular}{|c|c|c|c|}
\hline \multirow{2}{*}{$\begin{array}{c}\text { UNIDADE DA } \\
\text { FEDERAÇÃO }\end{array}$} & \multicolumn{3}{|c|}{ ANO } \\
\cline { 2 - 4 } & $\mathbf{1 9 9 9}$ & $\mathbf{2 0 0 0}$ & $\mathbf{2 0 0 1}$ \\
\hline RORAIMA & 1,3 & 1,5 & 1,8 \\
\hline AMAPÁ & 1,6 & 1,9 & 2,2 \\
\hline ACRE & 1,7 & 2,1 & 2,6 \\
\hline AMAZONAS & 7,6 & 9,7 & 12,4 \\
\hline RONDÔNIA & 4,0 & 5,4 & 7,2 \\
\hline PARÁ & 13,6 & 18,6 & 25,5 \\
\hline TOCANTINS & 3,3 & 4,2 & 5,3 \\
\hline SERGIPE & 4,5 & 5,9 & 7,8 \\
\hline CEARÁ & 28,2 & 33,3 & 39,4 \\
\hline PARAÍBA & 10,5 & 13,3 & 16,8 \\
\hline BAHIA & 41,9 & 52,8 & 66,5 \\
\hline RIO GRANDE DO NORTE & 9,2 & 11,4 & 14,1 \\
\hline PERNAMBUCO & 36,1 & 41,0 & 46,6 \\
\hline PIAUÍ & 7,8 & 10,2 & 13,3 \\
\hline ALAGOAS & 7,7 & 10,1 & 13,2 \\
\hline MARANHÃO & 10,1 & 14,5 & 20,9 \\
\hline SÃO PAULO & 217,5 & 242,9 & 271,3 \\
\hline RIO DE JANEIRO & 84,6 & 92,5 & 101,1 \\
\hline MINAS GERAIS & 62,7 & 75,9 & 91,8 \\
\hline ESPÍRITO SANTO & 12,8 & 14,9 & 17,3 \\
\hline PARANÁ & 35,8 & 42,2 & 49,7 \\
\hline SANTA CATARINA & 20,1 & 23,9 & 28,4 \\
\hline RIO GRANDE DO SUL & 39,0 & 46,4 & 55,2 \\
\hline DISTRITO FEDERAL & 11,9 & 14,1 & 16,8 \\
\hline GOIÁS & 21,4 & 24,4 & 27,9 \\
\hline MATO GROSSO & 10,7 & 12,7 & 15,1 \\
\hline MATO GROSSO DO SUL & 7,6 & 9,2 & 11,1 \\
\hline TOTAL BRASIL & $\mathbf{7 1 3 , 2}$ & $\mathbf{8 3 5 , 0}$ & $\mathbf{9 8 1 , 3}$ \\
\hline & & & \\
\hline
\end{tabular}

